\title{
Description of seafloor sediment and preliminary \\ geo-environmental report, Shelikof Stralt, Alaska
}

by

Monty A. Hampton, $\mathrm{Krls} \mathrm{H}$. Johnson,

Michael E. Torresan, and William $\mathrm{J}$. Winters

U.S. Geological Survey

Open-File Report 8y-1133

This report is preliminary and has not been reviewed for conformity with U.S. Geological Survey edicorial standards and stratigraphic nomenclature. Any use of trade names is for descriptive purposes only and does not imply endorsement by the USCS. 
INTRODUCTION

Shellkof Stralt, situated between t'e Kodiak island group and the Alaska Peninsula (Flg. 1), is included in OCS oil and gas lease area 60.

Environmental geologic studies are belng conducted by the U.S. Geological

Survey prior to the scheduled September 1981 sale date. Seismic-refiection

records, collected with $40-$ to $95-\mathrm{cm}^{3}$ airgun, 800 -joule minisparker, 800 -joule boomer, and 3.5-and 12-kilohertz systems and covering over $6,400 \mathrm{~km}$ of trackline have been examined to identify geologic conditions at or below the seafloor that might affect petroleum operations. Of the total trackline distance, $865 \mathrm{~km}$ were collected in June 1980 aboard the Geological Survey's ship R/V S.P. LEE. The remainder were collected by Nekton Inc. in 1979, under contract to the USGS (Fig. 2). Sediment samples were collected at 42 stations on the June 1980 cruise for geological and geotechnical analysis (fig. 2).

The purpose of this report is to present physlcal and chemical

measurements that have been made on sediment samples and to give a preliminary geo-environmental assessment of Shelikof Strait, based on presently completed analyses of the geophysical records and sediment samples.

\section{SETTING}

Shelikof Strait marks the location of a northeast-trending structural trough, forming an inner forearc basin (von Huene, 1979) that is located near the convergent margin of the North America plate where it is being underthrust by the Pacific plate. The major tectonic feature is a clearly defined Benioff zone, located at a depth of just less than $100 \mathrm{~km}$ beneath the strait (Puipan and Kienle, 1979). 
The Gulf of Alaska - Aleutian region, which includes sale area 60 , is one of the most seismically active on earth and accounts for about 7 percent of the annual worldwide release of seismic energy; mostly in the form of large earthquakes (greater than magnitude 6). Since recording of large earthquakes began in 1902, at least 95 potentially destructive events (M>6) have occurred in the vicinity of shelikof strait. Recurrence interyals of major earthquakes (M>7.5) within a given area along the Gulf of Alaska - Aleutian system have been estimated to be between a maximum of 800 years (Plafker and Rubin, 1967) and a minimum of 33 years (Sykes, 1971).

At least 12 volcanoes classified as active (within historic time) or recently active $(<10,00 \mathrm{yr})$ are located along the Alaska Penlnsula adjacent to the strait (Powers, 1958). The volcanoes are andesitic in composition and are subject to violent exuptions, as exemplified by the katmai event of 1912, which expelled more than $25 \mathrm{~km}^{3}$ of ash (wilcox, 1959). The most recent eruption was that of Mt. Augustine in 1976 in nearby lower cook Inlet. Onshore geology and sparse deep seismic-reflection data indicate chat many of the major geologic features of lower cook Inlet extend into shelikof Strait. These features include less than $2 \mathrm{~km}$ of cenozoic and an undertermined thickness of Mesozoic strata, the Alaska - Aleutian Range batholith, and the Border Ranges faut (Magoon et al., 1979). Bedrock within the strait is covered by a blanket of relatively undeformed Quaternary glacial anō marine sedimentary deposits.

\section{BATHYMETRY}

The bathymetry of shelikof strait is shown in Figure 3 . The map was prepared by hand-picking depths from 3.5- and 12-kilohertz profiles along all 
tracklines show in Figure 2, correcting depths to mean lower low water, computer posting and contouring, and manually smoothing the Elnal product. The seafloor of shelikof Strait consists of a gently southwest-sloping central platform bordered by narrow marginal channels adjacent to the Kodiak islands and the Alaska Peninsula. Water depths in the northeast part are generally less than $200 \mathrm{~m}$ whereas those in the southwest generally exceed $200 \mathrm{~m}$ ano can be as much as $300 \mathrm{~m}$. Superimposed on the platform are some local highs and lows with as much as $100 \mathrm{~m}$ relief. Along the axes of the marginal channels are several closed depressions of up to $100 \mathrm{~m}$ relief.

\section{SHALLOW STRUCTURES}

Figure 4 shows trends of shallow structures. Faults were identified in airgun, minssparker and uniboom records by the presence of offset strata and hyperbolic reflections. Only faults that disrupt sediment above bedrock were mapped, and distinction is made between those that intersect the seafloor and those that terminate below it. Fold axes were taken from the map prepared by Hoose and whitney (1980).

Most major structures trend parallel to the axis of the strait, perpendicular to the direction of plate convergence. Faults that offset the seafloor or extend above beorock into unconsolidated sediment occur along both margins of the strait. Faults in the central part of the strait cause as much as $100 \mathrm{~m}$ offset of the seafloor and produce horst and graben structures seen in some seismic reflection records (Fig. 5 ).

Shallow bedrock folds are asymmetric, with vergence toward the northwest on the Kodiak Island side of the strait and toward the southeast on the Alaska Peninsula side (Hoose and whitney, 1980). Most folds are truncated at the unconformable contact with overlying unconsolidated sediment. 


\section{SEDIMENT}

Stratigraphy: Sedimentary deposits of presumed pleistocene and Holocene age overlie an irregular unconformity above Tertiary and older sedimentary bedrock. Thickness of unconsolidated sediment, measured from airgun, minjsparker, and uniboom records, is generally about $100 \mathrm{~ms}$ of two-way acoustic penetration in the northeastern half of the study area and increases abruptly in the southwestern half to values exceeding 1000 ms (Fig. 6 ; see also whitney et al., $1980 \mathrm{a}, \mathrm{b})$. The thickening reflects a deepening of the unconformity. Interpretations of the seismic stratigraphy by whitney et al. (1980 a,b). Hoose et al. (1980), and Holden (1980) reveal that the section above the unconformity comprises three sedimentary units: a lowermost (Pleistocene?) unit that fills the bedrock depression in the southwest half of the area and reaches thicknesses of more than $500 \mathrm{~m}$, a lower Holocene unit generally about 100 in thick that overlies the unconformity in the northeast and the pleistocene unit in the southwest, and an upper holocene unit generally less than $20 \mathrm{~m}$ thick that covers most of the seafloor.

High-resolution seismuc reflection records show that the platform area on the seafloor of Shelikof strait represents the surface of a southwesterly prograding sediment body. This sediment body pinches out laterally across the strait to form the gently sloping seaward walls of the marginal channels (Fig. 7). The steep, landward channel walls appear to be fault scarps in some places, but more typically are the depositional surface of sediment derived from Pleistocene glaciers or the adjacent landmasses (Alaska Peninsula and Kodiak islands). Therefore, the channels are not erosional in origin but instead represent areas of little modern sediment accumulation. In fact, the overall sedimentary environment of Shelikof strait apparently is depositional, 
with no evidence of the exosion and large-scale reworking common nearby in Cook Inlet (Bouma et al., 1978) and on Kodiak Shelf (Hampton et al., 1979). Sedimentation reflects the dominantly barotropic flow of ocean water that enters the northeast end of the strait from cook Inlet and the Gulf of flaska (Schumacher et al., 1978; Muench and Schumacher, 1980).

Textures: Sedimentary textures were measured by sieving and pipetting into four size classes: coarse $(>2 \mathrm{~mm})$, sand $(2-0.062 \mathrm{~mm})$, silt (0.062$0.004 \mathrm{~mm})$, and clay $(<0.004 \mathrm{~mm})$. Textures of surficial sediment grade uniformly down the strait from muddy sand at the northeast end to slightly sandy mud at the southwest end (Figs. 8,9), indicating progressive sorting by present-day transporting currents. A general fining across the strait, towara the southeast, exists in the southwestern half of the study area.

Index physical properties: Geotechnical index properties have been determined for many of the sediment cores. These include vane shear strength, sensitivity, water content, grain specific gravity, and plasticity (Atterberg Iimits) (Table 1).

Vane shear tests were performed with a notorized device at a rotation rate of $90^{\circ} / \mathrm{min}$. The vane was $1 / 2$ inch diameter and $1 / 2$ inch high, inserted into the sediment to a depth twice the height of the vane.

Peak undisturbed strengths and remolded strengths were measured. On board ship, vane shear tests were performed at the ends of $1-m$ core sections immediately after recovery. The axis of vane rotation was parallel to the core axis in these tests. In the laboratory, within two weeks atter termination of the cruise, core sections were split longitudinally and vane shear tests were performed at $20-c m$ intervals with the axis of vane rotation perpendicular to core axes. Replicace measurements were made on matching 
halves of some cores. Some tests were performed using a torque cell to measure resistance to vane rotation; others were run using a spring. Peak vane shear strengths $\left(S_{u}\right)$ generally increase toward the northeast (Fig. 10, Table 1), reflecting the increase in grain size. Most of the sediment can be classified as very soft $\left(s_{u}(12 \mathrm{kilopascals})\right.$, but some is soft (12kPa<s $u(24 \mathrm{kPa})$ to medium $\left(24 \mathrm{kPa}<\mathrm{S}_{u}<48 \mathrm{kPa}\right)$. These values are within typical ranges for shallow marine sediment (e.g., Keller, 1968, 1974).

$S_{u}$ values ideally increase down core, reflecting an increase in effective stress and a decrease in water content. This is true for most cores in Shelikof Strait, except for cores at stations 530 and 550 , where strengths decrease. This strength reduction down core may be due to cementation of the near-surface sediment or an internal fabric effect (e.g., Bennett et al., 1977).

Replicate vane tests made on matching core halves fall into two groups. In the first, the replicate tests were both made with the torque-cell apparatus, whereas in the second, one test was made with the torque cell and the other was made using a spring to measure resistance to vane zotation. Peak undisturbed strengths and remolded strengths were measured. The results are summarized in Table 2. Differences between replicate measurements are expressed as $v$, the coefficient of variation ldifference between the two measurements, divided by the mean, expressed as a percent). As shown in the table, the range of $V$ is large (0-1138), but the averages and standard deviations are moderate. The mean of all replicate torque-cell measurements is 248 for both peak undisturbed strengths and remolded strengths. Standard deviations are $20 \%$ and $22 \%$, respectively. v-values for the torque-cell/spring replicate measurements have a grand mean of $22 \%$ for peak strengtins and $26 \%$ for remolded strengths, with standard deviations of 16 and 268 , respectively. 
Vane shear strength tests made at the ends of core sections measure strength ilong a vertical cylindrical surface within the sediment, whereas tests made on split core sections measure strength on a cylinorical suriace whose axis is perpendicular to the core axis and contains planes in all. directions from vertical to horizontal. Thus, end-core tests measure strength on planes that are nf different orientation than those on which strength is measured in a split-rorf test. Some difference in end-core and split-core values micht: be expected, becanse strength can be anisotropic in sediments. Moreover, Bjerrum (1973) demonstrated an inverse relation retween the magnitude of anisotropy (in a horizontal plane versus a vertical plane) and plasticity index using several different nacural clays. In order to make a similar analysis of Shelikof strait sediment, some adjustments of the data were made to account for the fact that end-core and split-core measurements were not taken at the same levels in cores. Narely, linear regression equations were derived for both the undisturbed and remolded split-core strengths as a function of water content for several cores with ailundant vane stxength data (Table 3). No anisotropy should exist for remoldea samples, so the difference between the remolded end-core measurements and the corresponding split-core regression line was considered to represent the real deviation from linearity, reflecting variacions within the sediment column that affect strength.

This diftererice, which also includes some experimental error, should be inherent in the indisturber strength values, too, so the deviation conputeo for the remolded strength was subtracted from the corresponding undisturbed strenqth. Then, this corrected value was divided into the corresponding (equal water content) value on the undisturbed, split-core regression line to qive a measure of anisotropy. As shown in fig. 11, nearly all split-core 
values exceed those from ends of cores, giving an anisotropy greater than one. No correlation with Bjerrum's (1973) experimental curve is evident, however.

Values of sensitivity, $S$, the ratio of undisturbed strength to remolded strength, fall in the low $(1<S<2)$ to quick (S>16) range (Terzaghi and Peck, 1948), with most being classified as medium sensitive ( $2<5<4$ ) (Table 1). The coarser sediment in the northeastern area tends to have higher sensitivity values (Eig. 12, Table 1 ).

Water content (as a percentage of dry sediment weight) generally decreases to the northeast, inversely correlating with grain size (Fig. 13, Table 1). Moreover, water contents increase across the strait, from the Alaska Peninsula to Kodiak Island. Values in the northeast are perhaps low for marine sediment, but most are in the range of measurements taken elsewhere (Keller, 1968, 1974).

Atterberg limits describe the plasticity of sediment, in terms of the liquid limit (water content separating plastic ano liquid behavior) and plastic limit (water content separating solid and plastic behavior). Useful derivatives are the plasticity index (difference between the liquid and plastic limits), and the liqudity index (position of the natural water content relative to the liquid and plastic limits). Certain trends in plasticity are evident in Shelikof strait. Liquid limit, plastic limit, and plasticity index increase down the strait toward the southwest, and also generally across the strait, toward the southeast (Table 1, figs. 14, 15, 16). These properties also generally increase with decreasing mean grain size (Eigs. 17, 18, 19), although the data for plastic limit are quite scattered. Plastic limits are less variable than liquid limits, which is typically the case (Mitchel1, 1976; Richards, 1962). 
Correlations have been made between liquid limit ( $w_{\ell}$ ) ana compressibility (Herrmann et al., 1972; skempton, 1944). The majority of Shelikof strait samples fall within the medium $\left(30<w_{\ell}<50\right)$ and high $\left(w_{\ell}>50\right)$ compressibility ranges.

All measured liquidity indices in Shelikof strait are greater than 1 (Table 1) which is usual for near-seafloor marine sediment. Most cores show a decrease in liquidity index with depth, reflecting the decrease in water content. Sediment with a liquidity index greater than one behave as a iquid when remolded.

A plot of liquid limit versus plasticity index - termed a plasticity chart (Casagrande, 1948) - shows a trend parallel to the A-line that divides basic soil types (Fig. 20). Most sediments from Shelikof strait plot below the A-line, which is typical of inoganic silts and silty clays. The linear trend of data points is expected for samples taken throughout the same sedimentary deposit (Terzaghi, 1955; Richaras, 1962).

Other index properties obtained include grain specific gravity, bulk sediment density (assuming 100\% saturation), void ratio, and porosity (Table 1). Sediment density decreases toward the southwest, whereas void ratio and porosity increase. Across the strait, toward the southeast, sediment density decreases, and void ratio and porosity increase. Grain speclfic gravicy varies over a small range, wich most values between 2.65 and 2.84. No trends are apparent. Typical variations with depth in cores are as follows: void ratio and porosity decrease, bulk sediment density increases, and grain density shows no trend.

Carbon: Dry-weight percentages of carbonate and organic carbon were measured for subsamples taken from the upper 2 to $3 \mathrm{~cm}$ of cores at 31 
locations in shelikof strait (Figs. 21, 22). Carbon-carbonate analysis was performed on a LECO model wR-12 carbon determinator with induction furnace and acid digestor. Subsamples were first freeze-dried, ground to a fine powder, and stored in a desjccator. Total carbon was measured using the induction furnace, and carbonate carbon was determined with the acid digestor. Organic carbon content is calculated as the difference between total carbon and carbonate carbon contents. The reported values of organic carbon and carbonate carbon represent the average of 3 analyses from each core. Surficial sediment of shelikof strait is characterized by low to intermediate contents of organic carbon, compared to other marine areas (Bordovskiy, 1965, 1969; Gardner, 1980; Lisitzin, 1972; Rashid and Brown, 1975). Values range from 0.108 to $3.16 \%$, averaging $0.82 \%$. Most values are between $0.40 \%$ and $1.50 \%$.

organic carbon content generally increases down the strait toward the southwest, as well as across the strait toward the southeast. These values vary inversely with grain size (Fig. 23). Correlations with other physical properties are shown in Figs. 24 through 28. Organic carbon content correlates positively with water content and plasticity index, whereas general inverse correlations are found with vane shear strength and sensitivity. Data are too scattered to define a correlation between organic carbon content anò liquidity index. Correlations similar to those described above have been reported by others for low organic-carbon content sediments (Bordouskiy, 1965, 1969; Bush and Keller, 1981; Keller et al., 1979, Lisitzin, 1972; Mitchell, 1976; Odell et al., 1960).

Percent carbonate carbon is typically low in shelikof strait sediment, varying between $0.84 \%$ and $38.76 \%$ (average $=2.96 \%$ ) (FIg. 22 ). Most values are 
less than 3.50\%. Two locations (535 and 553) with anomalously high values (21.678 and 38.768 , respectively) are near the boundary of the strait.

Clay mineralogy: Forty-four samples of surficial sediment were analyzed for clay mineralogy. Sample preparation and clay-mineral identification methods generally follow those presented by Hein et al. (1976). Samples were analyzed on a Picker high-angle x-ray diffractometer with a scintillation counter using nickel-tiltered copper ka radiation. Carbonate and organic carbon were removed from sediment samples with Morgan's solution (sodium acetate and glacial acetic acid diluted with distilled water) and $30 \%$ hydrogen peroxide, respectively.

The <2 um size fraction was separated by centrifugation. This clay-size fraction was Mg-saturated and mounted on glass slides (Gibbs, 1965). The mounts were glycolated and then heat-treated at $500^{\circ} \mathrm{C}$ for one hour. An $x-r a y$ diffractogram $\left(2 \theta=3^{\circ}-14^{\circ}\right)$ was taken Eollowing each of the above treatments.

The semiquantitative technique of measuring peak areas was used to calculate the relative clay-mineral percentages. Biscaye's (1965) peak area weighting factors of two for chlorite-kaolinite, four for illite, and one for smectite were used in calculating relative percentages. Percentages of chlorite relative to kaolinite were obtained Erom a slow scan of the $24^{\circ}$ $26^{\circ} 20$ diffractogram (Biscaye, 1954). Kaolinite was a minor component in these samples, making accurate determinations difficult. Biscaye's method showed no discernible kaolinite peak at $24.88^{\circ} 20^{2}$ The chlorite values presented here include any kaolinite that may have been present but was not measurable. Duplicate samples and duplicate sample runs showed reproducibility within 58 . 
Illite and chlorite are the dominant clay minerals in Shelikof strait, averaging $52 z$ and 428 , respectively (Figs, 29,30; Table 4). Mixed layer clay (mostly smectite) occurrence is minox and averages 6\% (fig. 31). The major gradients in clay mineral abundances occur across the strait, perpendicular to the axis. At the northeast boundary of the strait, however, gradients tend to become oblique to the axis. The highest values of illite and the lowest values of chlorite generally occur along the axis. Mixed layer clays occur more abundantly on the southeastern side of the strait compared to the northwestern side, and most abundantly at the northeast end of the strait.

The flow that transports clay minerals into Shelikof strait derives mainly from Cook Inlet and from the northeastern Gulf of Alaska (Muench and Schumacher, 1980). Clay mineral suites from these areas, as well as from nearby Kodiak Shelf, have been described by Hein et al. (1979). Average compositions of these suites, as well the average from Shelikof strait, are presented in Table 5. The clay mineral suite in Shelikof strait most closely resembles that from Cook Inlet, but some contribution from the northeastern Gulf (i.e., Copper River) surely is present.

The relative enrichment of chlorite and depletion of illite along the margins of the strait may represent contributions of clay minerals from the adjacent landmasses. Alternatively, the segregation might reflect hydraulic sorting processes (Gibbs, 1977; Knebel et al., 1977). Stratigraphic evidence (i.e.. the non-depositional channels) suggests that the margins of the strait are hydrodynamically high-energy areas, implying that clay minerals with relatively low settling velocities would be depleted, which apparently is the case. Knebel et al. (1977) demonstrated that chlorite and kaolinite in San Erancisco Bay gediment is coarser than illite, and that hydraulic sorting 
on the basis of size exists. The distribution of mixed layer clays in Shelikof strait, present in relatively small amounts and presumably finer grained than the other clays, shows a sorting trend, but it is not clearly compatible with that shown by the other clays. Mixed-layer clay distribution suggests a source from Kodiak Shelf.

Gas: Sediment samples at 15 stations were analysed for light hydrocarbon gases (methane through butane), by K. Kvenvolden and T. Vogel. In general, gas concentrations were low (Table 6). Methane was approximately 30 microliters/liter $(\mu 1 / 1)$ of wet sediment, ethane was about 100 nanoliters/liter $(\mathrm{nl} / \mathrm{I})$, propane was $100 \mathrm{nl} / \mathrm{l}$, and ethane was $80 \mathrm{nl} / \mathrm{l}$. Isobutane and n-butane were negligible.

One station showed anomalous gas concentrations. Sediment from station 539 exhibited large methane $(1600 \mu)$ and ethane (946 nl/1) concentrations. The sample was unusual, because the methane/ethane + propane ratio was high $\left\{C_{1} / C_{2}+C_{3}=1556\right)$ indicating biogenic gas, and yet the ethane/ethene ratio was also high $\left(C_{2} / C_{2: 1} * 16\right)$, suggesting a thermogenic source. Ethene is normally the same concentration or greater than that of ethane in biogenic gases, but due to the low concentrations of the other saturated hydrocarbons (propane, iso-butane, and n-butane), the gas at station 539 can be assumed biogenic.

\section{ACOUSTIC ANOMALIES}

Anomalous acoustic signatures exist in many boomer and minisparker records. Typically, they appear as unusually strong reflections, with abrupt terminations, within the unconsolidated sediment section. Reflectors below the anomaly are commonly obscured. A few instances where all refiectors 
beneath the seafloor are totally obscured, with no evidence of strong reflectors, were also found.

Anomalies occur most commonly in the northeastern half of the strait, but some also exist in the southwest (Fig. 32). Many anomalies occur over steeply dipping bedrock strata and anticlinal crests that have been truncated by erosion (Fig. 33).

Acoustic anomalies are not all easy to distinguish, because a continuous gradation exists from normal acoustic returns, through subtle deviations from normal, to distinct anomalies. Instrument settings, such as filter Erequencies and gain modes (TVG versus $A G C$ ), have an influence on the appearance of anomalies. It is commonly a matter of judgment what to identify as a true acoustic anomaly. Only distinct anomalies are mapped on Fig. 32. Acoustic anomalies have been shown in other areas to be caused by gas charging (Nelson et al., 1978; Whelan et al., 1976; Schubel, 1974). A similar causative relationship has not been confirmed in Shelikof strait, but it cannot be discounted. The occurrence of some anomalies over truncaced anticlines and steeply inclined bedrock strata is consistent with an origin due to migrated gas, but the absence of significant concentrations of gas in cores and of of water-column gas seeps in the seismic recoras argues against it, unless, of course, the gas is completely trapped and cannot leak to the surface. Alternatively, the anomalies may be due to change in lithology along stratigraphic horizons.

\section{CRATERS}

Seafloor craters occur over an area of approximately $1500 \mathrm{~km}^{2}$ on the progradational platform in shelikof strait (fig. 34). The craters appear on 
seismic reflection profiles as small indentations, typically $50 \mathrm{~m}$ in diameter and less than $5 \mathrm{~m}$ deep (Fig. 35). Broad, low relief rims about $1 \mathrm{~m}$ high can be detected on some. In side-scanning sonar records, the craters are subtle features and circular in plan (P.J. Hoose, personal comminication). The craters are similar in appearance to those found on the scotian shelf by King and MacLean (1970). Disruption of seismic reflectors cannot be detected beneath most craters. Moreover, nearly all craters occur on the present-day seafloor. Only a few examples of buried craters were found (Figs. 34 and 35 ), and most of these occur within a subbottom depth of $25 \mathrm{~m}$.

Origin of the craters is unknown, but one possibility is venting of either gas or buried, liquefied sediment. The lack of disruption of seismic reflectors suggests a shallow source; less than a few meters. Gas venting is believed to cause craters in other places, such as in Norton Sound where a buried Pleistocene peaty mud is the source of gas (Nelson et al., 1979). No evidence of an organic-rich layer was detected in shelikof strait cores, and as mentioned above, measured contents of hydrocarbon gases are low. Furthermore, the location of acoustic anomalies, which are also believed typically to be related to gas (Nelson et al., 1978; whelan et al., 1976; Schubel, 1974), are almost mutually exclusive of the locations of craters in Shelikof strait.

There is an interesting correlation of the occurrence of craters with the subsurface extent of the thick Pleistocene( $r$ ) unit of whitney et al. $(1980 a, b)$. The two are nearly coincident. But if the two features were related, some disturbance of the intervening $100 \mathrm{~m}$ or so of unconsolidated sediment would be expected, which is not the case. 
Alternatively, craters might be formed by collapse or venting of buried liquefied sediment. In particular, a layer of Katmai ash blankets most of the strait and was encountered in many cores. At nearly all locations within the crater field, penetration of the gravity core was stopped at subbottom depths of less than $35 \mathrm{~cm}$. Dart coring at one locality revealed a dense layer of ash about $15 \mathrm{cr}$ thick at this depth. Perhaps this material and other ash layers were originally deposited in a loose state and have liquefied after burial, although this process does not account for the relief of the craters, which is much greater than the thickness of ash recovered in cores.

Liquefaction, if it has occurred, could have been caused by a severe earthquake such as the one in 1964. On the other hand, the area is too deep for storm-wave loading to cause liquefaction (e.g., Hampton et al., 1978 ).

\section{SEDIMENT SLIDES}

Examination of seismic reflection records shows that the seafloor of Shelikof strait is nearly devoid of sediment slides. Only one instance of a slide mass was found (Eigs. 4, 36), and it was derived from an adjacent fault scarp. The slide mass extends for about $100 \mathrm{~m}$ along one trackline and is less than 10 m thick.

Although most of the seafloor is flat, several steep slopes exist in Shelik of Strait. Namely, the Landward walls of the marginal channels and the large-offset fault scarps in the central part of the strait have declivities that commonly exceed the resolving capability of the seismic reflection system (about $15^{\circ}$ ) and may locally approach vertical. Evidently, the sediment underlying these slopes is generally strong enough to resist the downsope driving forces of gravity ano earthquake accelerations. 
ENVIRONMENTAL ASSESSMENT

The tectonic setting of shelikof strait, near the convergent margin of two major lithospheric plates, makes it subject to large earthquakes. The minimum recurcence interval of 33 years for a major earthquake that could affect the entire region might be exceeded by the lifetime of an oil-producing province, because the last major event was in 1964. So, although earthquakes cannot be predicted with confidence, seismic hazards are a valid concern for offshore development. Strong ground shaking, fault rupture, sediment displacement, and tectonic deformation have all been documented in nearby areas. Examination of the distribution of historic epicenters shows no areal concentrations (H. Pulpan, Univ. Alaska, personal communication), such as exist nearby on Kodiak Shelf (Hampton et al., 1979), that would imply some areas are more susceptible to local seismic affects than others.

Violent volcanic explosions are also associated with the tectonic setting, and eruptions from the volcanoes on the Alaska Peninsula could cause problems such as substantial ash accumulations and acid rains. More destructive but local effects such as hot ash flows are not likely in most parts of the strait.

The faults in Shelikof strait that offset the seafloor imply recent activity and the probability of more to come. The seafloor offset (100 $\mathrm{m})$ of some faults in the central part of the strait implies major movement in recent times. The short extent, irregular shape, and horst-like appearance of these Eaults suggest that perhaps they are caused by forces associated with localized uplift rather than being a direct result of regional compression. The sedimentary environment of Shelikof strait is depositional, with sandy material presently being deposited to the northeast and progressively 
finer material accumulating to the southwest. Problems associated with scour or movement of large bedforms, a significant concern on Kodiak Shelf and in lower cook Inlet, should not exist in Shelikof strait. Accumulation of fine sediment does raise the possibility of pollutant storage on the seafloor, though. pollutants introduced within the strait itself or in more diluted form from lower cook Inlet and the northeastern Gulf of Alaska could be stored as contaminants on fine particles.

Seafloor sediment in Shelikof strait exhibits physical properties (vane shear strength, water content, plasticity) similar to those of marine sediment elsewhere. Measurements of physical properties are useful for categorizing the shallow sediment types in the strait, but deeper samples and more sophisticated testing would be necessary for engineering design purposes. A few high values of sensitivity and compressibility were obtained, but most measurements of physical properties are in normal ranges for shallow marine sediment, and no unusual geotechnical problems are indicated. Deeper unconsolidated sediment apparenty is stable, coarse-grained glacial debris. Geotechnical triaxial and consolidation testing now underway will give more detailed strength and consolidation information than is now available for the uppermost sedimentary units.

Sediment slides are uncommon in the strait; only one occurrence is known. Nevertheless, the steep slopes along fault scarps and also along the landward side of the marginal channels must be regarded as possible sites of local instability.

Indirect evidence for gas-charged sediment, in the form of acoustic anomalies, is especially common in the northeast part of the strait and warns that weak and unstable sediment, as well as high gas pressures, might be 
presence of gas-charged sediment, although the locations of craters is nearly exclusive of the locations of acoustic anomalies, which argues against this. A more likely explanation for the craters is sediment venting due to liquefaction. A source at depths of less than about 10 meters below the seafloor is likely for the liquefied layer, and therefore the venting may represent only a minor environmental concern.

\section{ACKNOWLEDGMENT}

This study was jointly funded by the U.S. Geological survey and the Bureau of Land Management through interagency agreement with the National Oceanic and Atmospheric Administration, under which a multi-year program responding to needs of petroleum development of the Alaskan continental shelf is managed by the outer Continental Shelf Environmental Assessment Program (OCSEAP) office. 


\section{REFERENCES CITED}

Bennett, R. H., Bryant, W. R., and Keller, G. H., 1977, Clay fabric and geotechnical properties of selected submatine sediment cores from the Mississippi Delta: NOAA Professional Paper 9, $86 \mathrm{p}$.

Biscaye, P. E., 1964, Distinction between kaolinite and chlorite in recent sediments by $x$-ray diffraction: Am. Mineralogist, v. 49, p. 1281-1289.

Biscaye, P. E., 1965, Mineralogy and sedimentation of Recent deep sea clay in the Aclantic Ocean and adjacent sea and oceans: Geol. Soc. America Bull., v. 76, p. 803-832.

Bjerrum, L., 1973, problems of soil mechanics and construction on soft clays and structurally unstable soils: Proceedings of the Eighth International Conference on Soil Mechanics and Foundation Engineering, v. 3, p. 111159.

Bordovskiy, 0. K., 1965, Accumulation of organic matter in bottom sediments: Marine geology, v. 3, e. 33-82.

Bordovskiy, 0. K., 1969, organi = matter of recent sediments of the Caspian Sea: Oceanology, v. 9, p. 799-807. 
Bouma, A. H., Hampton, M. A., Rappeport, M. L., Whitney, J. W., Teleki, P. G., Orlando, R. C., and Torresan, M. E., 1978, Movement of sandwaves in lower Cook Inlet, Alaska: Preprints 10th offshore Technology Conference, p. $2271-2284$.

Bush, W. H., and Keller, G. H., 1981, The physical properties of Peru-Chile continental margin sediments - the influence of coastal upwelling in sediment physical properties:

, in press.

Cassagrande, A. 1948, Classification and identification of soils:

Transactions, American Soc. Civil Engineers, v. 113, p. 901-991.

Feely, R. A., and Massoth, G. J., 1981, Sources, composition, and transport of suspended particulate mater in lower cook Inlet and northwestern Shelikof Strait, Alaska: in Bouma, A. H. (ed.), Geology of Lower Cook Inlet: U.S. Geological Survey Professional paper, in press.

Gardner,J. V., Dean, W. E., and Vallier, T. L., 1980, Sedimentology and geochemistry of surface sediments, outer continental shelf, southern Bering Sea: Marine Geology, v. 35, p. 299-329.

Gibbs, R. J., 1965, Error due to segregation in quantitative clay mineral x-ray diffraction mounting techniques: Am. Mineralogist, v. 50, p. 741751.

Gibbs, R. J., 1977, Clay mineral segregation in the marine environment: Jour. Sedimentary Petrology, v. 47, p. 237-243. 
Griffin, J. J., and Goldberg, E. D., 1963, Clay-mineral distributions in the Pacific Ocean: in The Sea--ideas and observations on progress in the study of the seas, $y .3$, The earth beneath the sea and history: Interscience Publishers, N.Y., p. 728-741.

Hampton, M. A., Bouma, A. H., Pulpan, H., and von Huene, R., 1979, Geoenvironmental assessment of the Kodiak Shelf, western Gulf of Alaska: Proceedings 11 th offshore Technology Conference, p. 365-376.

Hampton, M. A., Bourna, A. H., Sangrey, D. A., Carlson, P. R., Molnia, B. E., and Clukey, E. C., 1978, Quantitative study of slope instability in the Gulf of Alaska: Preprints loth offshore Technology Conference, p. 23082318

Hein, J. R., Bouma, A. H., Hampton, M. A., and Ross, R. C., 1979, Clay mineralogy, Eine-grained sediment dispersal, anò inferreơ current patterns, lower Cook Inlet and Kodiak Shelf: Sedimentary Geology, v. 24, P. 291-306.

Hein, J. R., Scholl, D. W, and Gutmacher, C. E., 1976, Neogene clay minerals of the far NW Pacific and southern Bering sea: Sedimentation and Diagenesis: in Bailey, S. W. (ed.), proceedings of the International Clay Conference, 1975, Mexico City. Applied Publishers, Itd., wilmette, I11. , P. $71-80$. 
Keller, G. H., Lambert, D. N., and Bennett, R. H., 1979, Georechnical

properties of continental slope deposits - Cape Hatteras to Hydrographer Canyon: Soc. Economic Paleontologists and Mineralogists Special Publication 27, Q. 131-151.

King, L. H., and Maclean, B., 1970, Pockmarks on the Scotian ShelE: Geol. Soc. America Bull., v. 81, p. 3141-3148.

Knebel, H. J., Conomos, T. J., and Commeau, J. A., 1977, Clay-mineral variability in the suspended sediments of the san Erancisco Bay System, California: Jour. Sedimentary Petrology, v. 47, p. 229-236.

Lisitzin, A. P., 1972, Sedimentation in the World Ocean: Soc. Econonlc Paleontologists and Mineralogists Special publication 17, 218 p.

Magoon, L. B., Bouma, A. H., Fisher, M. A., Hampton, M. A., Scott, E. W., and Wilson, C. L., 1979, Resource report for proposed oCS sale no. 60, lower Cook Inlet - Shelikof Strait, Alaska: U.S. Geological Survey Open-File Rept. $79-600,38 \mathrm{p}$

Mitchell, J. K., 1976, Fundamentals of Soil Behavior: New York, John Wiley and Sons, Inc., 422 p.

Muench, R. D., and Schumacher, J. D, 1980, Physical oceanographic and meteorological conditions in the northwest Gulf of Alaska: NOAA Technical Memorandum ERL PMEL-22, 147 p. 
Nelson, C. H., Kvenvolden, K. A., and Clukey, E. C., 1978, Thermogenic gases in near-surface sediments in Norton Sound, Alaska: Rreprints 10 th OEfshore Technology Conference, P. 2623-2633.

Nelson, C. H., Thor, D. R., Sandstorm, M. W., and Kvenvolden, K. A., 1979, Modern biogenic gas-generated craters (sea-floor "pockmarks") on the Bering shelf, Alaska: Geol. Soc. Anerica Bull., v. 90, p. 1144-1152.

Odell, R. T., Thornburn,T. H., and Mckenzie, L. T., 1960, Relationships of Atterberg limits to some other properties of Illinois soils: Proceedings of the Soils Society of America, v. 24, p. 297-300.

Plafker, G., and Rubin, M, 1967, Vertical tectonic displacements in southcentral Alaska during and prior to the great 1964 earthquake: Jour. Geosci. Osaka City Univ., p. 53-72.

Powers, H. A., 1958, Alaska Peninsula - Aleutian Islands: in Williams, H. (ed.), Landscapes of Alaska, University of California Press, p. 61-75.

Pulpan, H., and Kienle, J., 1979, Western Gulf of Alaska seismic risk: Preprints 11 th offshure Technology Conference, p. 2209-2218.

Rashid, M. A., and Brown, J. P., 1975, Influence of marine organic compounds on engineering properties of remolded sediment: Engineering Geology. v. 9 , p. $141-154$. 
Richaras, A. F., 1962, Investigation of deep-sea sediment cores, II. Mass physical properties: U.S. Navy Hydrographic office Tech. Rept. 106, 146 p.

Schumacher, J. D., Sillcox, R., Dreves, D., and Muench, R. D., 1978, winter circulation and hydrography over the continental shelf of the northwest Gulf of Alaska: NOAA Tech. Rept. ERL 404-PMEL 31.

Schubel, J. R., 1974, Gas bubbles and the acoustically inpenetrable, or turbid, character of some marine sediments: in I. R. Kaplan (ed.), Natural Gases in Marine Sediments, New York, Plennum Press, p. 275-298.

Skempton, A. W, 1944, Notes on the compressibility of clays: Geological Society of London, Quarterly Journal, v. 100, P. $119-135$.

Sykes, L. R., 1971, Aftershock zones of great earthquakes, seismicity gaps, and earthquake prediction for Alaska and the Aleutians: Jour. Geophysical Research, v. 75, p. 8021-8041.

Terzaghi, K., 1955, Influence of geological factors on the engineering properties of sediments: Economic Geology, 50th Anniversary Volume 19051955 , p. $557-618$.

Terzaght, K., and Peck, R. B., 1948, Soil Mechanics in Engineering Practice: New York, John Wiley and Sons. 
von Huene, R., 1979, Structure of the outer convergent margin off kodiak Island, Alaska, from multichannel seismic records: in watkins, J. S., Montadert, L., and Dickerson, P. W., (eds.), Geological and Geophysical Investigations of Continental Margins, AAPG Memoir 29, Tulsa, Anerican Association of Petroleum Geologists, p. 261-272.

Whelan, T., Coleman, J. M., Roberts, H. A., and Suhayda, J. N., 1976, The occurrence of methane in recent deltaic sediments ano its effect on soil stability: International Assoc. Engineering Geologists Bull., no. i4, p. $55-64$.

Whitney, J., Holden, K. D., and Lybeck, L., 1980a, Isopach map of Quaternary glacial-marine sediments, outer continental shelf, shelikof strait, Alaska: U.S. Geological Survey Open-File Report 80-2036, 1 p.

Whitney, J., Hoose, P. J., Smith, L. M., and Lybeck, L., 1980b, Geologic cross sections of the outer continental shelf, shelikof Strait, Alaska: U.S. Geological Survey Open-File Report 80-2036, 1 p.

Wilcox, R. E., 1959, Some effects of recent volcanic ash falls with special reference to Alaska: U.S. Geol. Survey Bull., no. 1028-N, p. 409-476. 


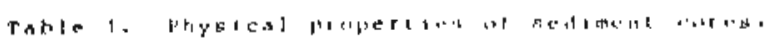

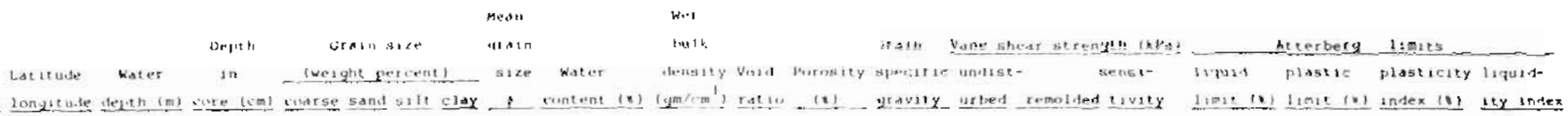

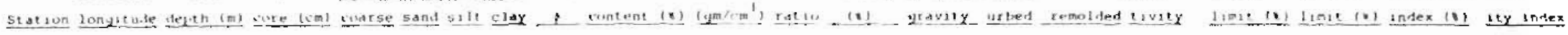

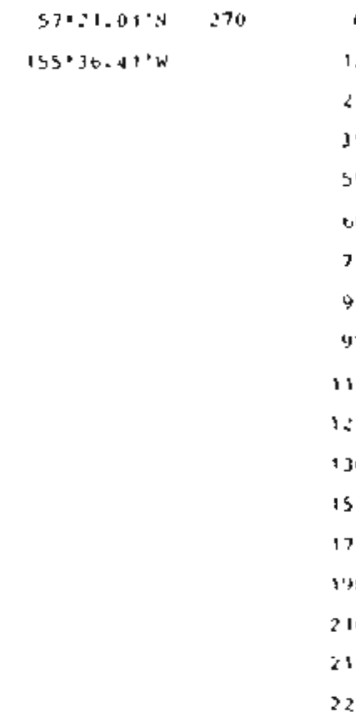

40
4,34 \&5 8.0

I. 4 T 50 T.9

7. $24454 \quad 4,0$

104.2

1. 41. 2.1 .5 7.6

2.34

$10+1.2$

$1.44 \quad 2.92 \quad 7.5 .5$

145.1

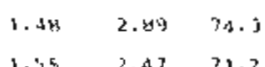

2.81

2.6

$3.1 \quad 4.40$

6. $2.10 .1,0$

$5.4 \quad 1.6 \quad 1.3$

$\begin{array}{llllllll}45.2 & 1.37 & 2.14 & 70.5 & 2.87 & 9.0 & 2.5 & 3.4\end{array}$

16.5 4.5 ‥

$1 \mathrm{no}$

(4) 40 a1.0

Bs. 9

1.59

$2.260 .6 \%$

2.1474 .9

2.85

$2.71 \quad 4 . x^{*} \quad 2.0^{*} \quad 2.0$

$2.4511 .6 \quad 4.13 \quad 2.9$

32.9

$4,7,6$

$\begin{array}{lllll}17 & 7 & 313 & 55 & 7.4\end{array}$

2.494

$2.91 \quad 40$

41.0

4.6 .7

0210040

5.5
$2.89 \quad 11.4$

1. 50 2.14 6\%.

$1.54 \quad 1.2409 .1$

1. HG 6.5 .0

$2.85 \quad 11$.

2.80
159

10

2742

1.84

s

3

$3 x$

1.55

67

4

24

1.43 


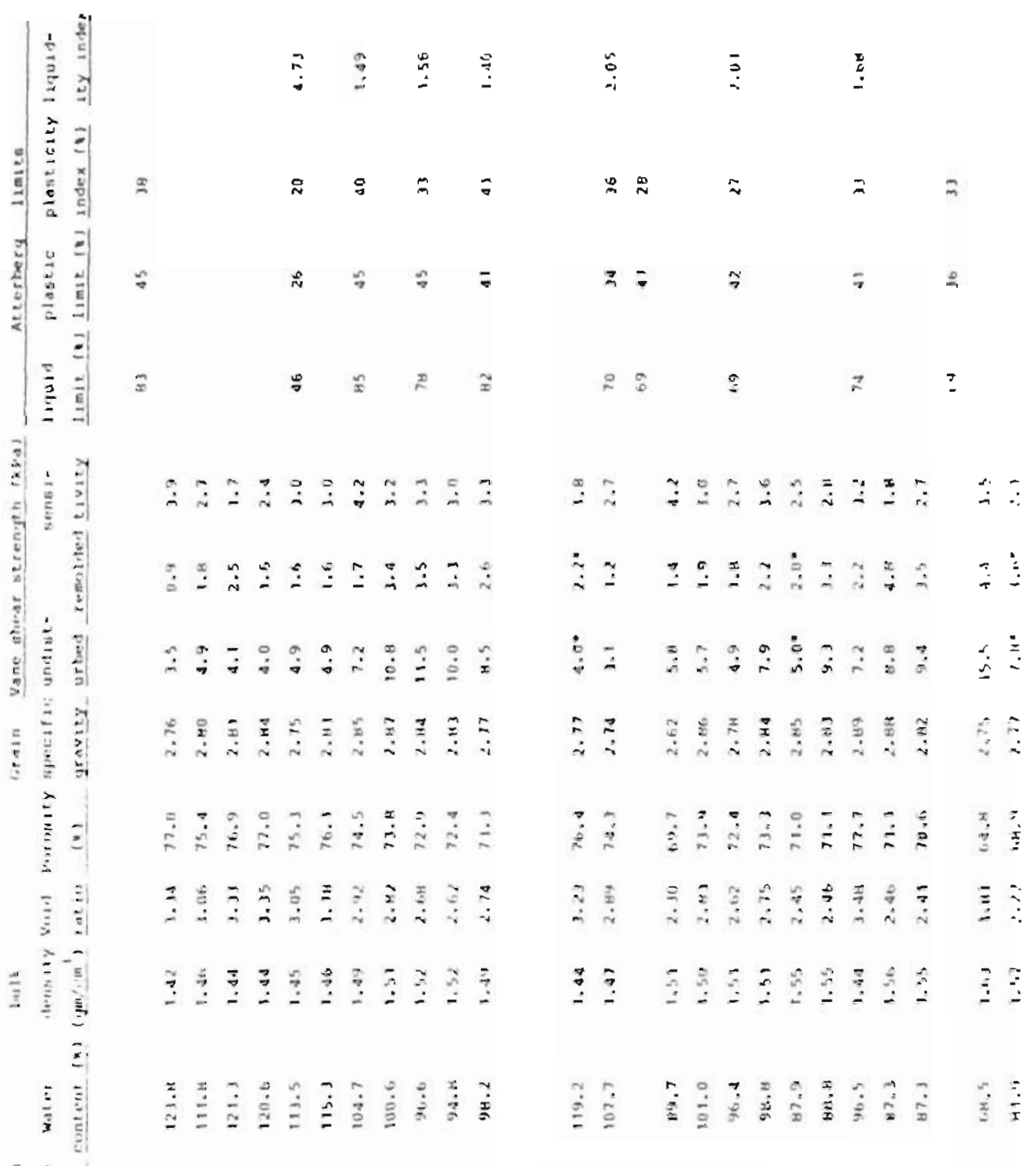

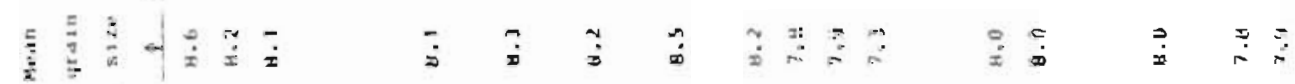

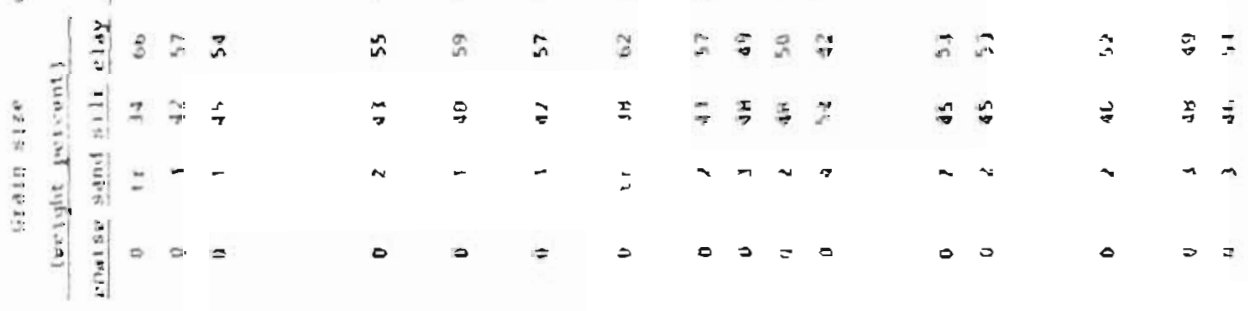

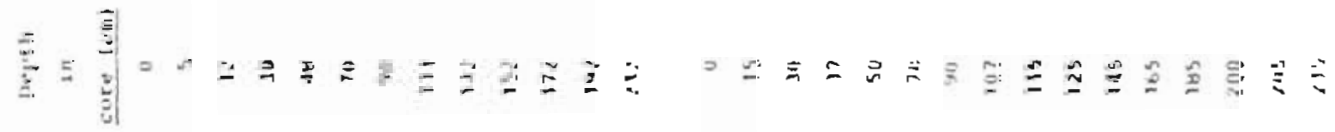

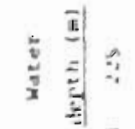

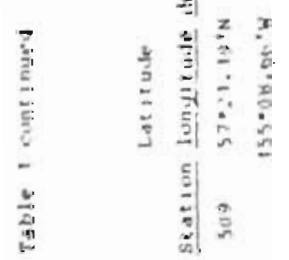




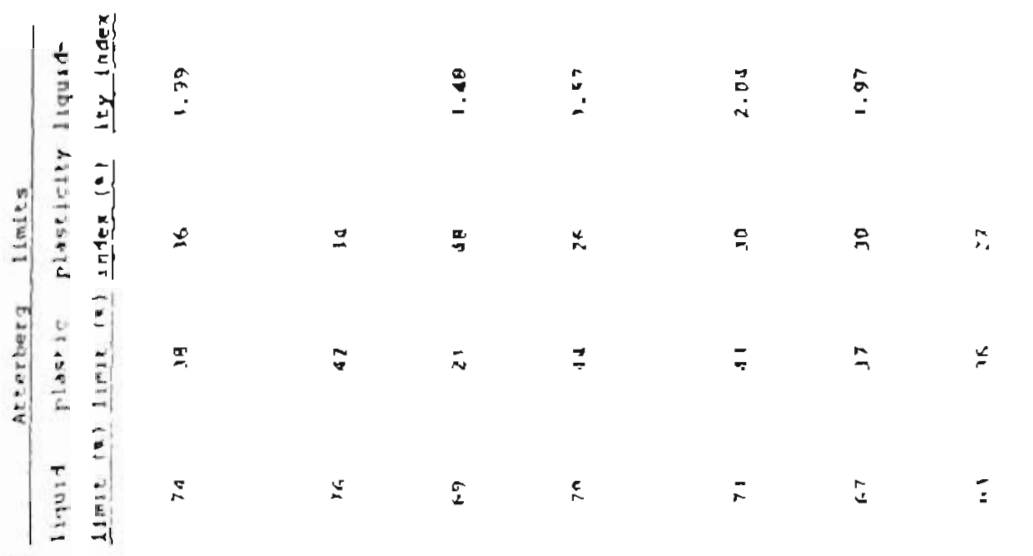

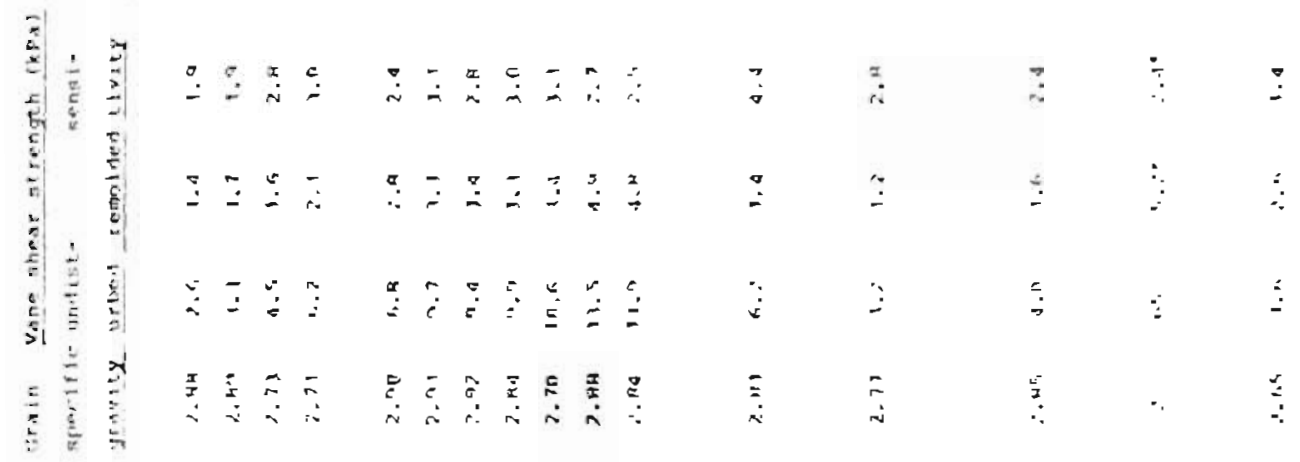

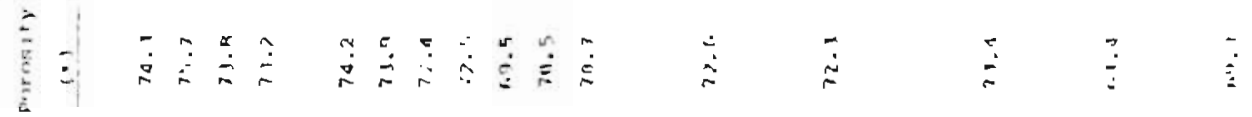

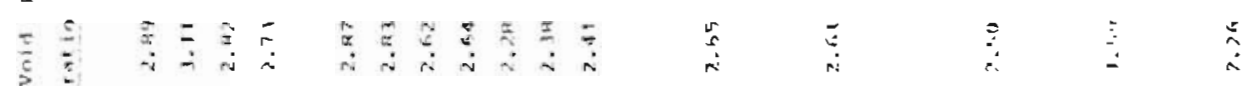

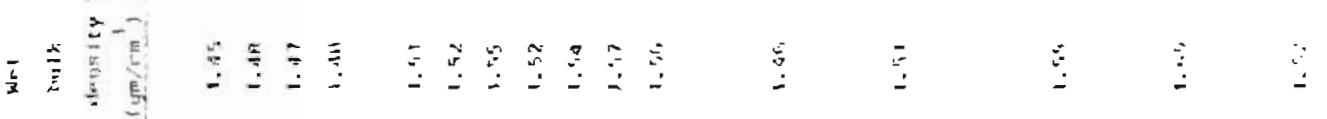

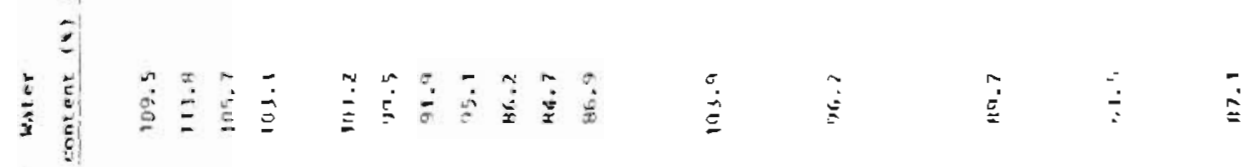

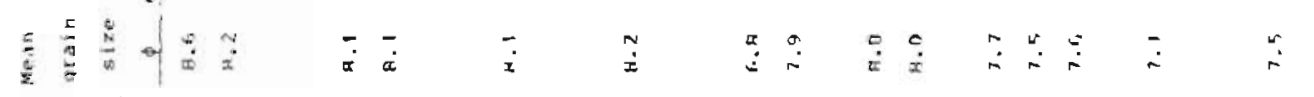

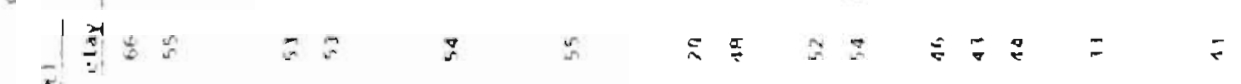

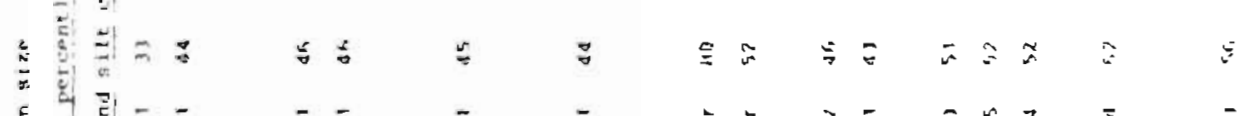

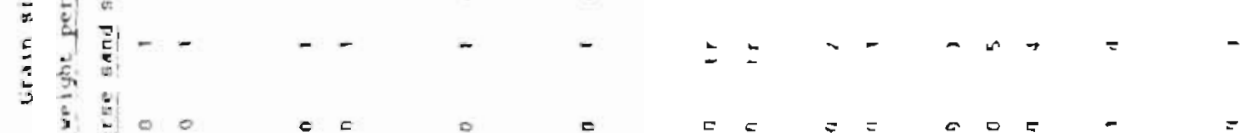

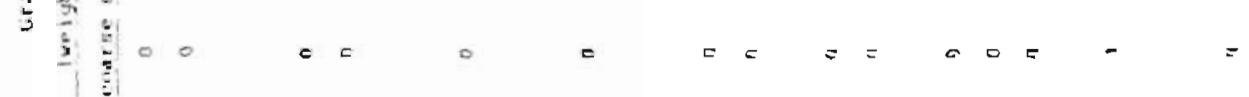

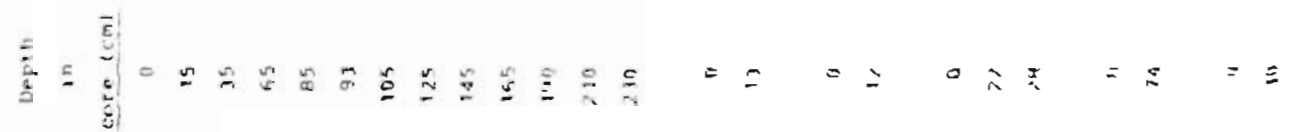
(c)

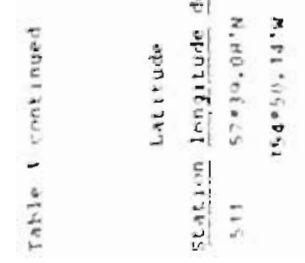

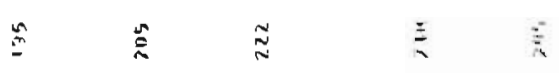

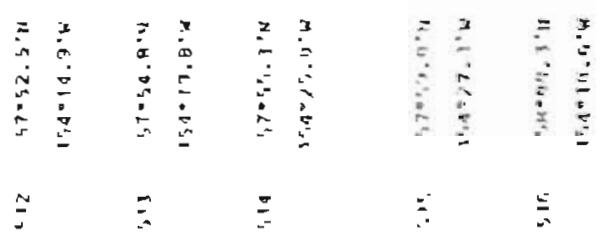




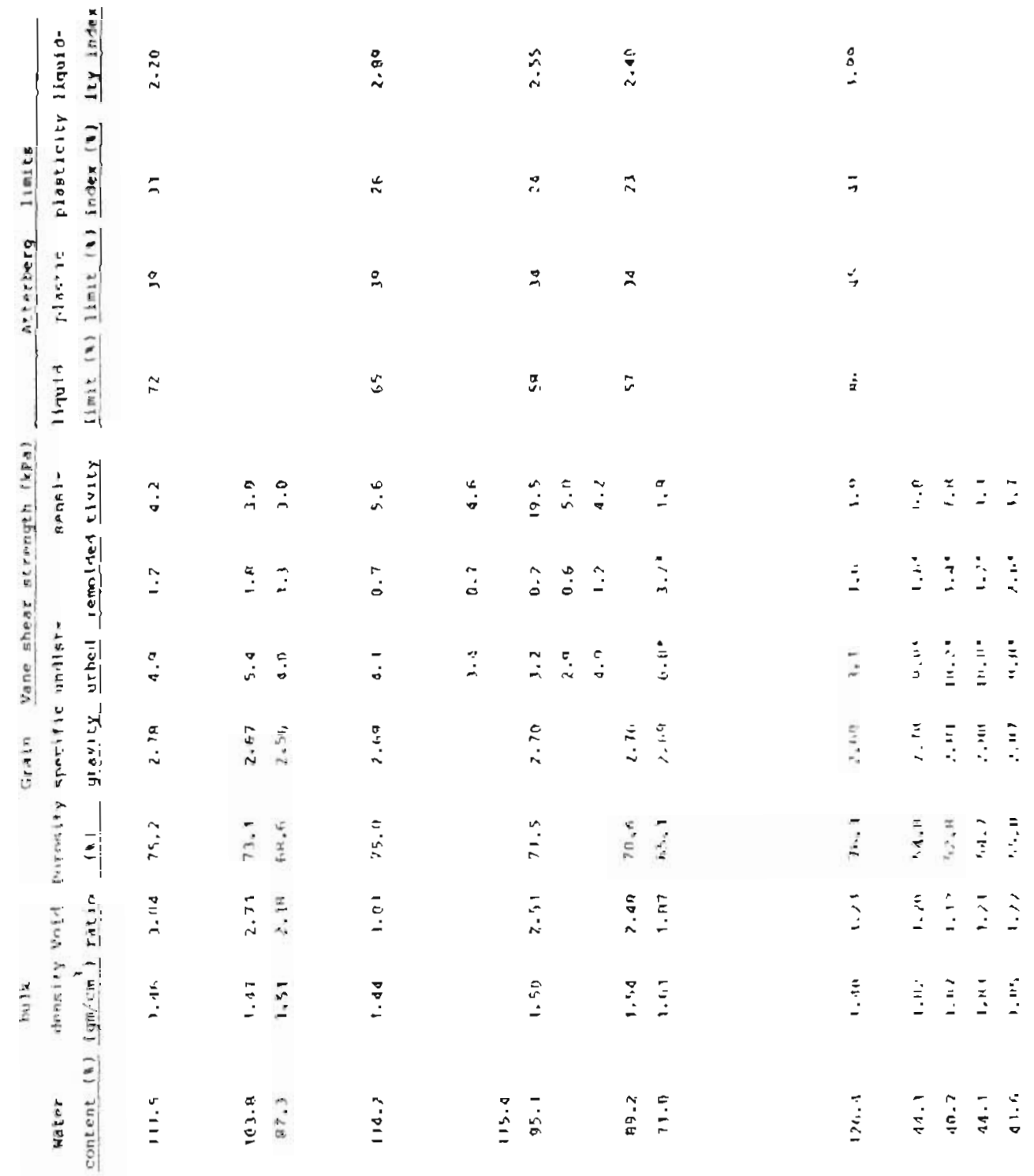

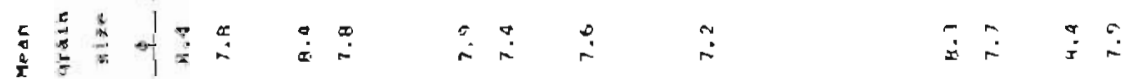

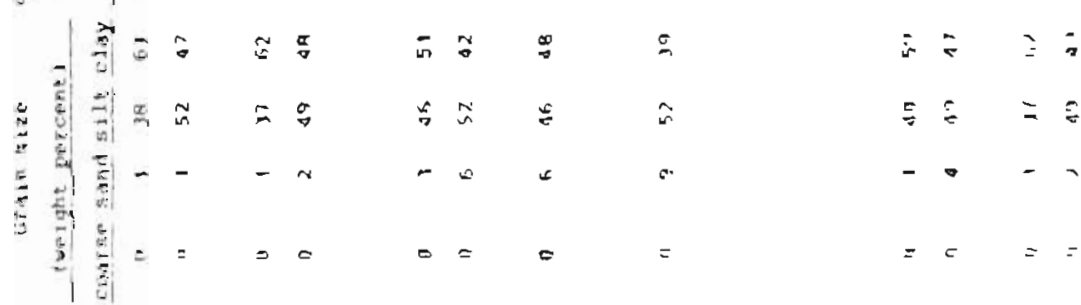

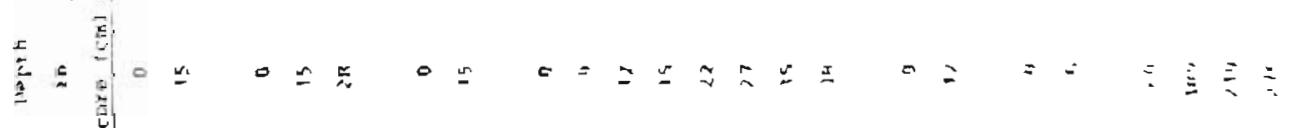

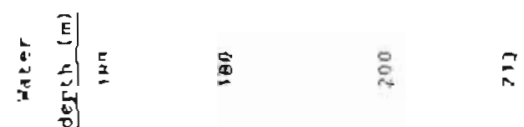

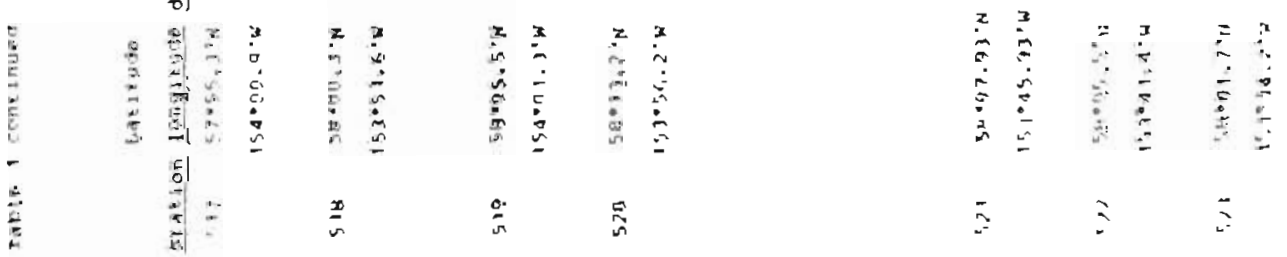




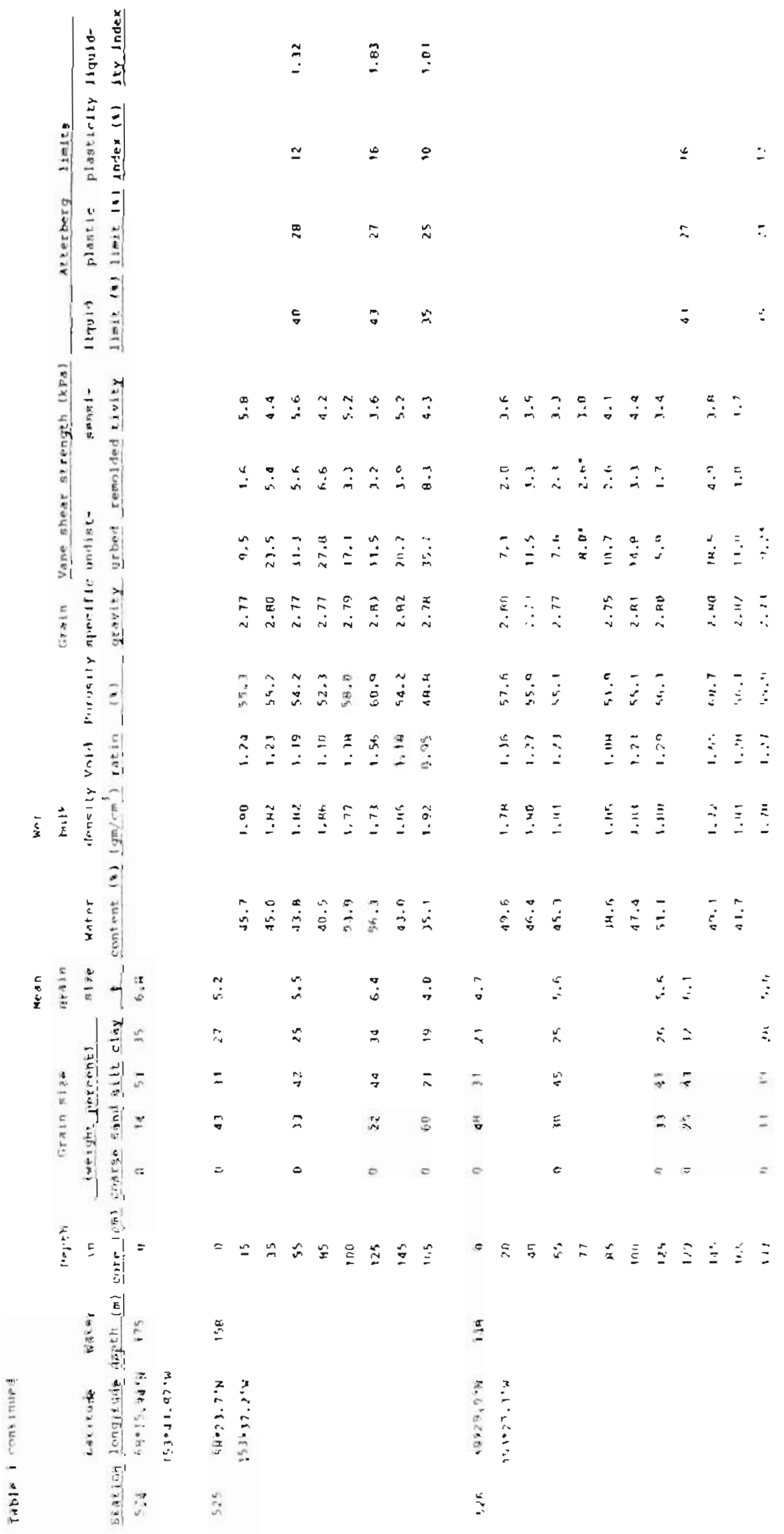




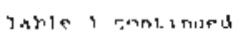

\begin{tabular}{|c|c|c|c|c|c|c|c|c|c|c|c|c|c|c|c|c|c|c|c|}
\hline \multirow{3}{*}{$\begin{array}{l}\text { Latcitude } \\
\text { nf longleude }\end{array}$} & \multirow{3}{*}{$\begin{array}{c}\text { Water } \\
\text { depth_my }\end{array}$} & \multirow{2}{*}{$\begin{array}{l}\ln 1 \times 14 \\
\text { in }\end{array}$} & \multirow{2}{*}{\multicolumn{4}{|c|}{$\begin{array}{l}\text { Gratn aixn } \\
\text { iwe } 2 \text { gite perconc? }\end{array}$}} & \multirow{2}{*}{$\begin{array}{l}\text { Mean } \\
\text { triin } \\
\text { size }\end{array}$} & \multirow[b]{2}{*}{ Hater } & batk & & & risinan & \multirow{2}{*}{\multicolumn{3}{|c|}{ 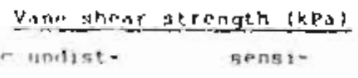 }} & \multicolumn{3}{|c|}{ Alterberg 11 mits } & \multirow{3}{*}{$\begin{array}{l}\text { 1:quid- } \\
\text { iţx } 1 \text { index }\end{array}$} \\
\hline & & & & & & & & & nenstly & volu & pormsity & spuncifir & & & & 117uid & plastic & plastxelty & \\
\hline & & core $(\mathrm{cm})$ & conatse & sant & silt & clay & $\Leftrightarrow$ & content (N) & $\left(\mathrm{gm} / \mathrm{cm}^{3}\right)$ & ratio & 121 & graviey & - urbed. & remolded & tenty & Hemt 19 & IImit W) & 2 dex $1 \times 1$ & \\
\hline $5,4 \cdot 34,2 \cdot \mathrm{N}$ & 153 & 0 & 0 & $3 h$ & 23 & 21 & 4.3 & & & & & & & & & & & & \\
\hline $15,3 \cdot 17.5 \%$ & & $150 *$ & 11 & 42 & חו & 17 & 3.9 & 36.8 & 1.90 & $1, n_{0}$ & $3 n .7$ & 2.78 & $n r_{n}, 4$ & 4.9 & 3.4 & 14 & 22 & 12 & 1.23 \\
\hline & & 21 & & & & & & 37.7 & 1. में & 1.01 & $3 \pi, 7$ & $\therefore .7 \mathrm{~A}$ & 11.11 & $1 . \theta^{*}$ & 1.2 & & & & \\
\hline & & 15 & & & & & & 33.1 & 1.95 & 0.90 & 87.3 & 2.77 & 19.4 & 4.7 & 1.9 & & & & \\
\hline & & 5 & & & & & & 32.4 & 1.74 & $\pi .417$ & $4 h+4$ & 2.74 & 91.6 & 2.9 & 4.8 & & & & \\
\hline & & $5 \%$ & & & & & & 34.4 & 8.92 & 0.92 & AH. & 2.71 & & & & & & & \\
\hline & & גים & 19 & $\sqrt{n} 9$ & $" 1$ & 9 & 2.4 & $3, r_{1}$ & $1,13 r_{1}$ & n. 8.4 & idj. & 2.73 & 15.2 & 3.3 & 4.6 & 20 & & & \\
\hline & & 73 & & & & & & $y^{m}, 0$ & I. H's & 1.03 & $50 . \mathrm{A}$ & $2.7 a$ & 26.7 & 6.5 & 4. : & & & & \\
\hline & & 115. & 13 & 59 & 20 & 17 & 1.3 & $3 h .3$ & 1. & 0.94 & 49.4 & 2.65 & 16.1 & 1.7 & $A \cdot 3$ & 29 & 3 & 5 & 2.22 \\
\hline & & 173 & & & & & & 23.3 & 2.07 & 0.62 & $\left.39_{-}\right\}$ & 2.72 & $19.19 \%$ & $3.2^{\circ}$ & 6.0 & & & & \\
\hline $54.37 .4 \%$ & $15 \%$ & $\pi$ & q & 33 & 37 & 29 & $5+0$ & & & & & & & & & & & & \\
\hline $15900.7 \times W$ & & 15 & 1 & 97 & $3 \mathrm{~A}$ & 24 & 5.2 & 40.6 & 1. HA & 1 . nis & 32.0 & 2.13 & 21.7 & 4.2 & 5.2 & is & 23 & 12 & 1.47 \\
\hline & & $"$ & & & & & & 53.5 & 1. 7 & 1.44 & 59.0 & 2.35 & 15.6 & & & & & & \\
\hline & & $r_{4}$ & & & & & & 47.9 & $1.71^{13}$ & 1.10 & $5 m+5$ & 2.74 & $11.6^{*}$ & $\therefore H^{4}$ & 4.2 & & & & \\
\hline & & ': & & & & & & 41.8 & 1.9. & 1.20 & 34.8 & $2 .+1$ & 16.6 & 8.0 & 1.8 & & & & \\
\hline & & $\cdot$ & '. & $\Delta 1$ & $3 n$ & 27 & 5.7 & 49.1 & 1.75 & 1,24 & $5+1,7$ & $2,+4,5$ & $1 \cdots 4$ & 1.5 & 1.8 & 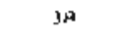 & 26 & 12 & 1.92 \\
\hline & & 94 & & & & & & 34.2 & 1.117 & $1 . n$ & 511.4 & 7.72 & 15,6 & 3.1 & 5.0 & & & & \\
\hline & & $\because 4$ & & & & & & 44.7 & 1. $4 \pi$ & 1.17 & 54.0 & 3 & $2 \lambda$, & A. & 1.4 & & & & \\
\hline & & $14 r_{1}$ & 'r & $m$ & 15 & 15 & $\mathrm{r} . \mathrm{n}$ & $B A, 11$ & $1.7 i$ & 1.41 & $\mathrm{Sit}_{0} \mathrm{a}$ & 2.71 & $m_{-} r$ & ' & $\therefore .8$ & 10 & 24 & $i s$ & 2.00 \\
\hline & & 1,7 & & & & & & $a x_{1}-b_{n}$ & 1. ist & ו' 1. & $q_{1} \cdots, 1$ & $\therefore 70$ & $17 . n \cdot$ & $5,12 *$ & 2.9 & & & & \\
\hline & & $17 t$ & & & & & & 47.1 & $1 . M$ & $1, \ldots r_{n}$ & $r_{1} c_{n}, x_{n}$ & $\cdots \cdots$ & 17.7 & 4. & $1, \pi$ & & & & \\
\hline & & 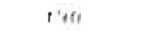 & & & & & & r.s. & 1.1 & דיו 1 & $1, H_{+}$ & 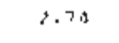 & $\ldots$. & 1.4 & i." & & & & \\
\hline & & $\therefore+1$ & $:$ & $\boldsymbol{I r}_{1}$ & 19 & $" 1$ & $\tau_{1} .4$ & $3, n$ & 1.16 & '. 1 & 4.7 .4 & $\therefore$ & $11 \ldots$. & i. & 1.3 & *. & $" 1$ & 5 & \&.:4 \\
\hline & & $\therefore a$ & & & & & & did & $1 . \cdots$ & 1.11 & , n. . I & $\therefore 1461$ & $1 \cdots x$ & t." & 1." & & & & \\
\hline & & $\therefore$ & & & & & & 41.4 & t. .111 & $1 .+1,1$ & '...' & 2,11 & $\| . . \cdot$ & 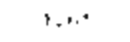 & 19.4 & & & & \\
\hline
\end{tabular}




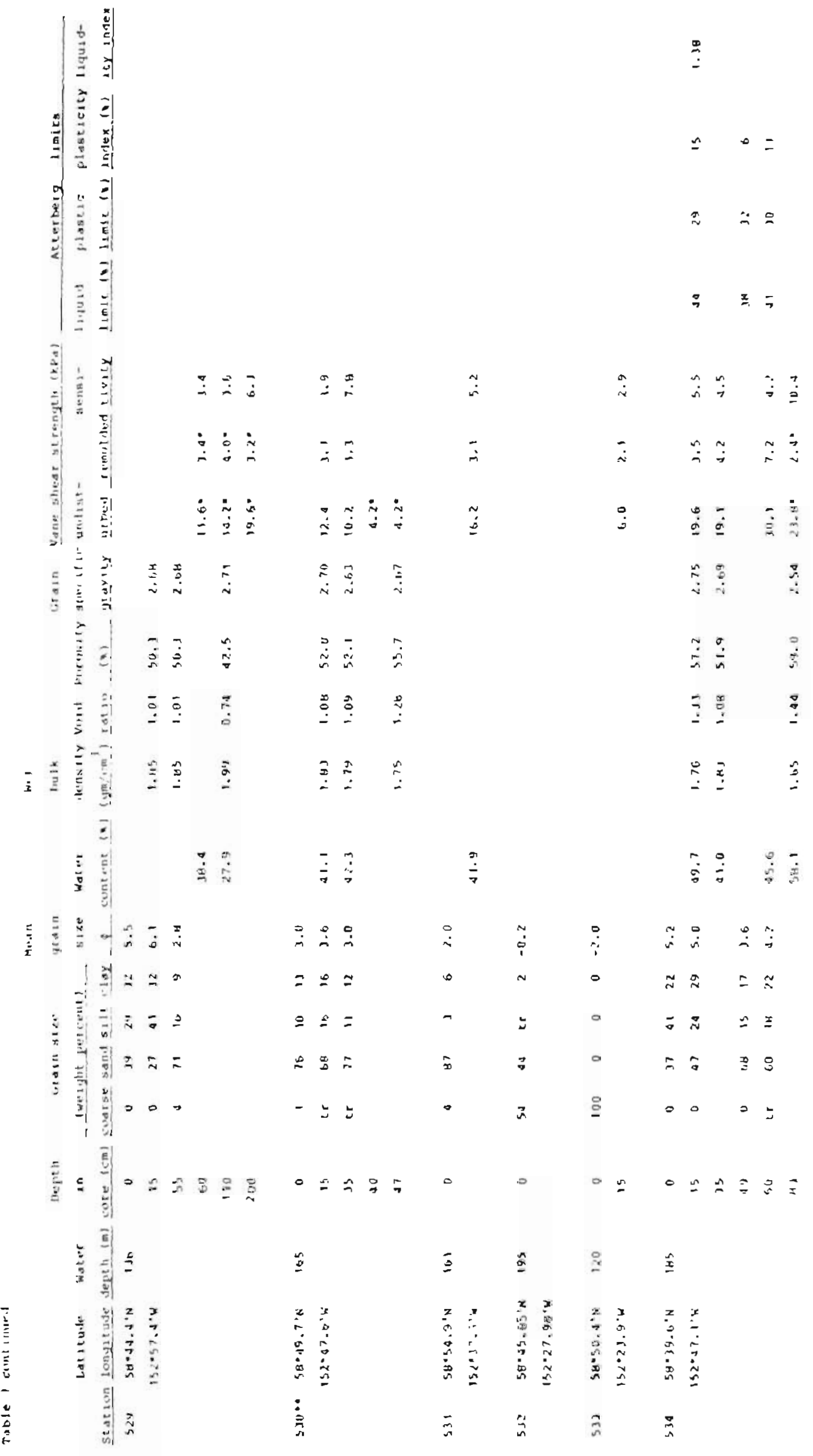




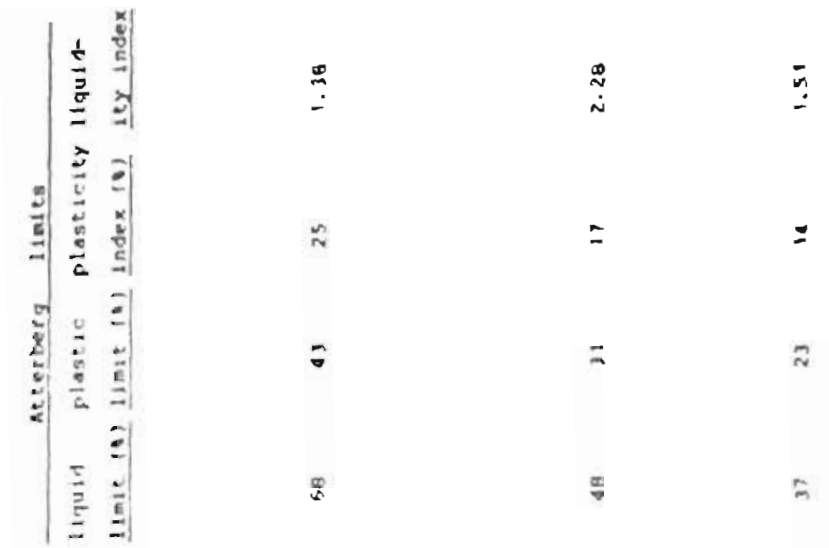

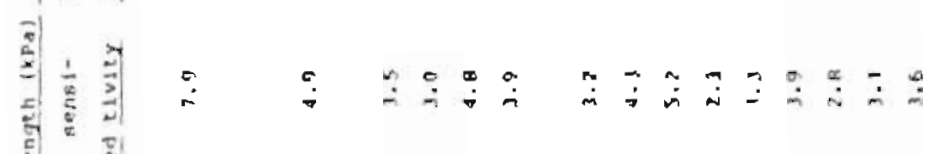

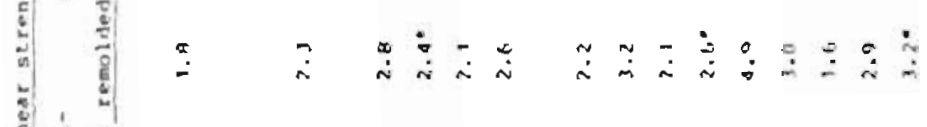

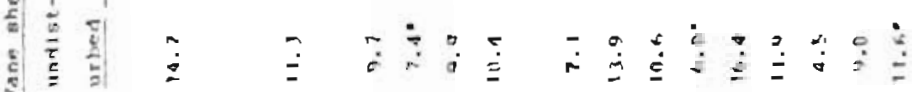

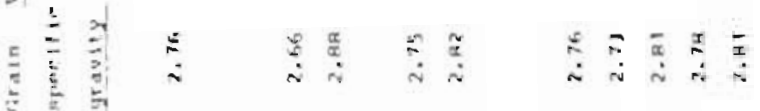

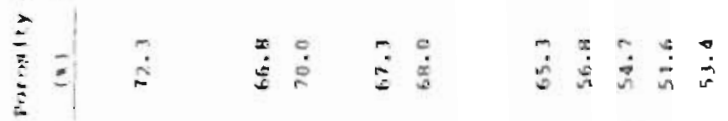

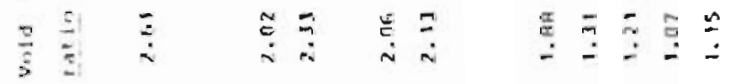

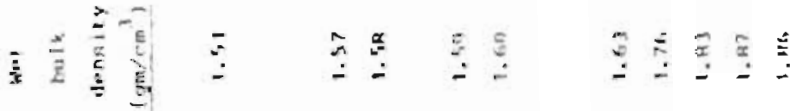

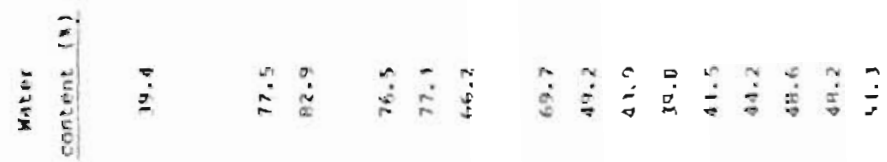

$$
\begin{aligned}
& \text { E } \\
& \mid-1)=\text { : }
\end{aligned}
$$

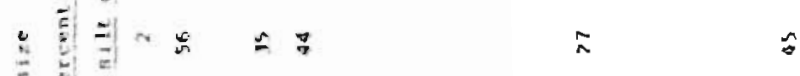

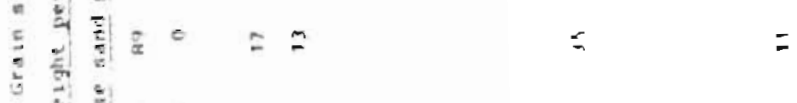

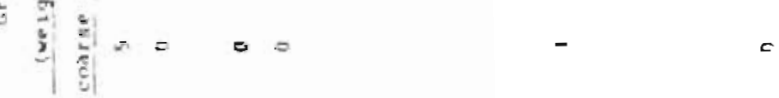

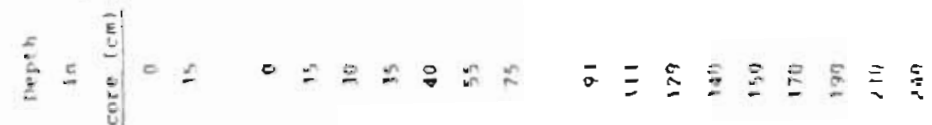

$$
\begin{aligned}
& x+\frac{1}{2}
\end{aligned}
$$

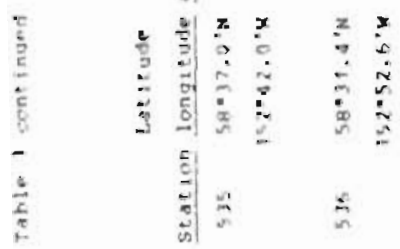


Table I rentrinturt

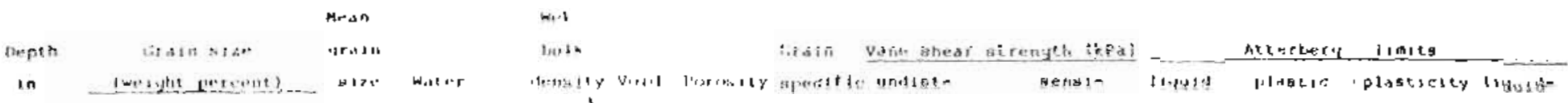

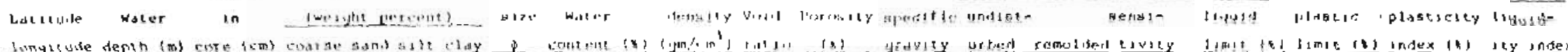

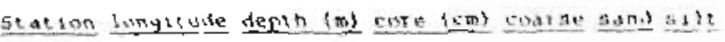
$537 \quad 54=29040$

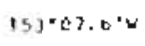

\begin{tabular}{|c|c|c|c|c|c|c|}
\hline 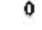 & 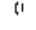 & 21 & in & 41 & 7.6 & \\
\hline 20 & 4 & 14 & 44 & is & $1 . !$ & $6 \ldots b$ \\
\hline 40 & & & & & & 64.5 \\
\hline 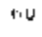 & & & & & & G.1.3 \\
\hline 75 & w & 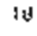 & بالا & as & 7.4 & \\
\hline 45 & & & & & & $6,4.7$ \\
\hline ive & & & & & & 511.4 \\
\hline $1: 0$ & & & & & & 71.2 \\
\hline 139 & 0 & 37 & 32 & Hi & 5.6 & 35.1 \\
\hline 157 & & & & & & 53.8 \\
\hline 186 & & & & & & 54.5 \\
\hline IHSS & & & & & & 54,7 \\
\hline
\end{tabular}

\begin{tabular}{|c|c|c|c|c|c|}
\hline 0 & n & 14 & 15 & d & 7. \\
\hline 15 & 0 & 46 & 24 & ij & 5.1 \\
\hline \multicolumn{6}{|l|}{24} \\
\hline \multicolumn{6}{|l|}{15} \\
\hline \multicolumn{6}{|l|}{35} \\
\hline 75 & 0 & 7 & 42 & 31 & 7.7 \\
\hline \multicolumn{6}{|l|}{45} \\
\hline \multicolumn{6}{|l|}{115} \\
\hline \multicolumn{6}{|l|}{124} \\
\hline 105 & a & I8 & H & 44 & 7.0 \\
\hline \multicolumn{6}{|l|}{155} \\
\hline \multicolumn{6}{|l|}{175} \\
\hline $1+4$ & 0 & 26 & & 35 & 6.2 \\
\hline \multicolumn{6}{|l|}{ גטנ } \\
\hline 24 & & & & & \\
\hline
\end{tabular}

\begin{tabular}{|c|c|c|c|c|c|c|}
\hline 77.9 & 1.5 .4 & 2.44 & 70.8 & 2.79 & 7.3 & 2.1 \\
\hline UF. .9 & 1.54 & 2.41 & 70.7 & $2, n$ & 11.20 & 3.2. \\
\hline 86.9 & 1.55 & 2.36 & 20.3 & 2.78 & 9.9 & $3+3$ \\
\hline 74.2 & 1.58 & 2.15 & 64.2 & 2.37 & 13.9 & J.A \\
\hline 86.4 & 1.53 & 2.36 & 70.2 & 2.79 & 4,1 & 2.4 \\
\hline $7 \cdot . s$ & 1.59 & 2.20 & GH.8 & 2.82 & 14.9 & 4.0 \\
\hline b.s.z & 1.69 & 1.77 & (6.4.0) & 2. H? & 24.7 & 6.7 \\
\hline 63.1 & 1.67 & 1.71 & 6. & 2.77 & $23.0 \%$ & $5 . \theta^{*}$ \\
\hline TU. 2 & 1.62 & 1.89 & 65.4 & 2.75 & 15. 世 & 4.2 \\
\hline 35.0 & וד.'י & $1 . A 4$ & פ. ני & 2.78 & 24.2 & 8.9 \\
\hline$x, x^{2}$ & $1.5 \mathrm{sin}$ & 2.33 & 69.9 & 2.42 & 22.2 & 5.9 \\
\hline S.4.4 & 1.32 & 1.31 & fu.z & $2 . \%$ & 24.6 & 5.0 \\
\hline$n_{3}, 1$ & $1,1.6$ & 1.77 & E... & 2.74 & 17.0 & 6.4 \\
\hline 01.1 & $1.1 \% 1$ & 1.65 & 62,2 & 2.39 & $16.4^{2}$ & 5. $\mathrm{H}^{-}$ \\
\hline
\end{tabular}


Tatis 1 entinuest

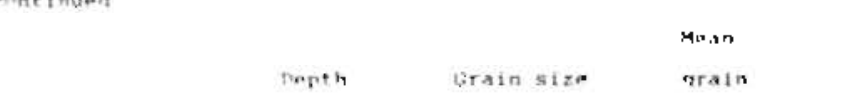

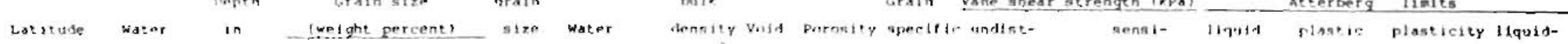

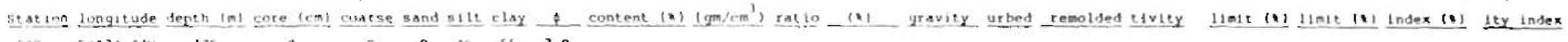

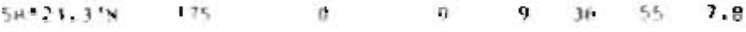

$153 \times 12.4 \mathrm{~m}$

$\sin$

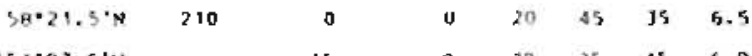

$153.097 .6^{\circ} \%$

$20 \quad 35 \quad 45 \quad 6.9$

\begin{tabular}{|c|c|c|c|c|c|c|c|}
\hline 75.9 & $1.5,14$ & 2.01 & 56.8 & 2.68 & $13.5,4$ & $2.8 \%$ & 4.8 \\
\hline 79.2 & $1.5 ;$ & 2.15 & 6.1 & $\therefore>1$ & $10.5^{\circ}$ & 4.0. & 1. 1 \\
\hline 51.5 & 1.75 & 1.40 & 5 H., 3 & 2,77 & 23.00 & $6.2^{\circ}$ & 4.3 \\
\hline 69.2 & 1.79 & 1.12 & $50, n$ & 2. Hח & 2 I.F" & 5.00 & 0.8 \\
\hline
\end{tabular}

I.4 $59+15.924 \quad 167$

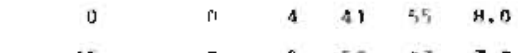

F.14.14.6'18 155

$151.25,9.4$

$57 \quad 37 \quad 7.2$

96.1

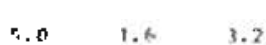

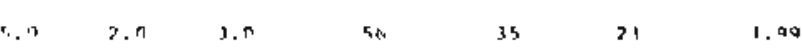

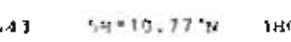

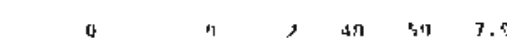

$153031.37 \% \mathrm{~W}$

76.1

\begin{tabular}{|c|c|c|c|c|c|c|}
\hline 1. 5,4 & 2,47 & 71.2 & 2.82 & $0, \pi$ & 3.24 & J. I \\
\hline 3.37 & 4.18 & 40,7 & $2 . \mathrm{Al}_{3}$ & $7.2^{\circ}$ & $4.10^{*}$ & 1.3 \\
\hline 1.54 & $\therefore 81$ & 71.1 & 2.81 & $10.2^{\circ}$ & $3.2^{\circ}$ & 3.1 \\
\hline
\end{tabular}

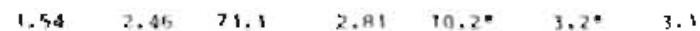

thereng 


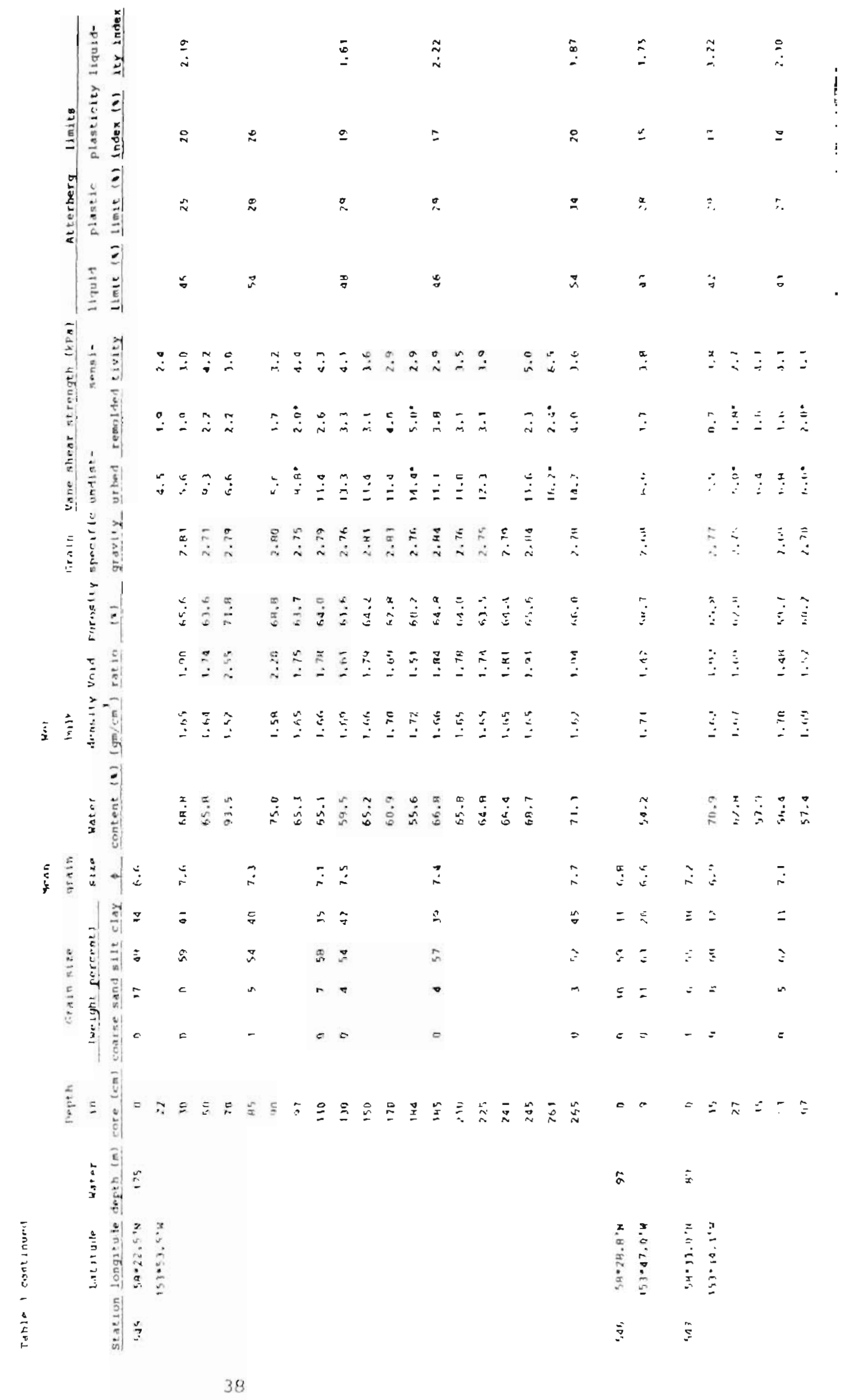




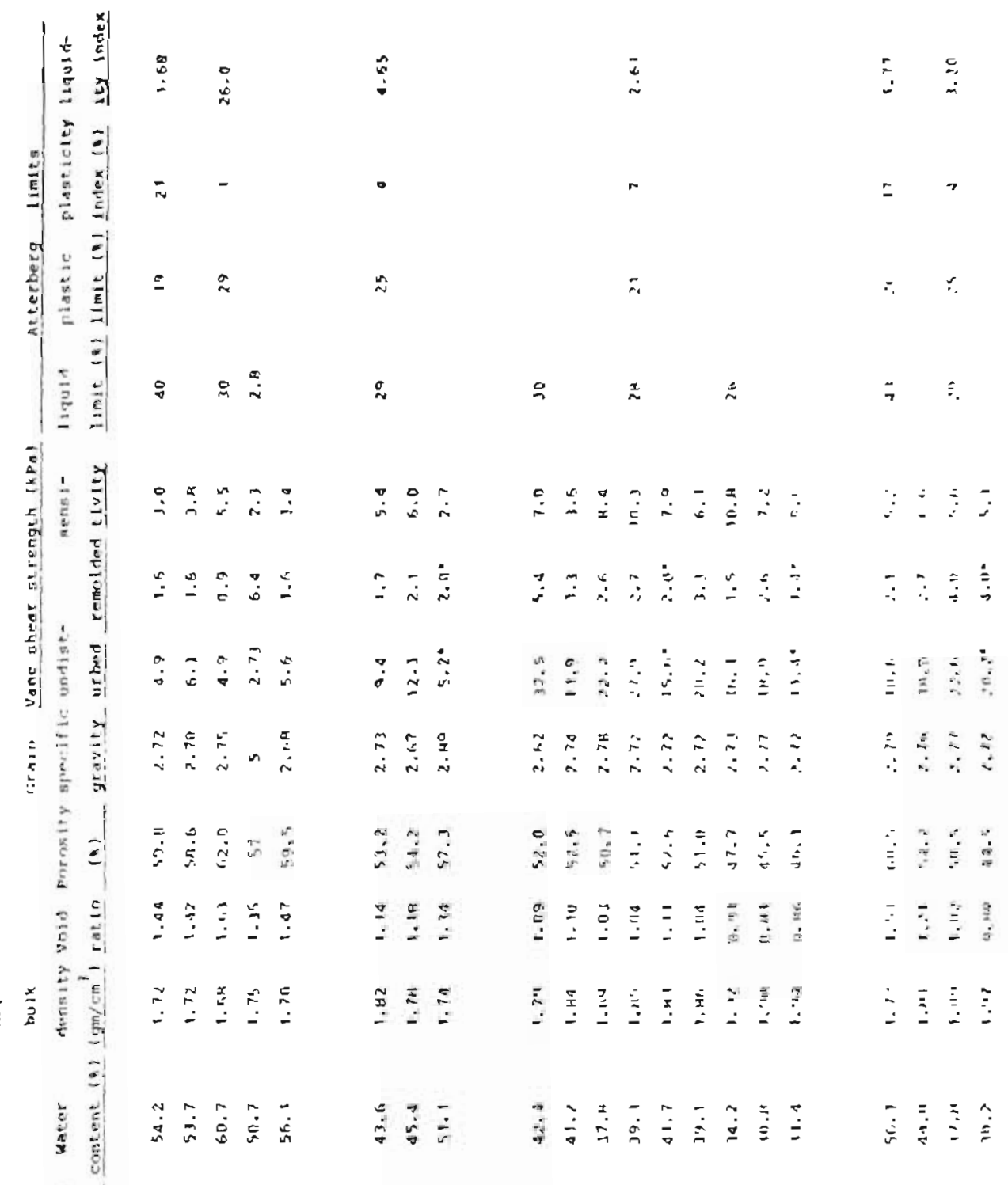

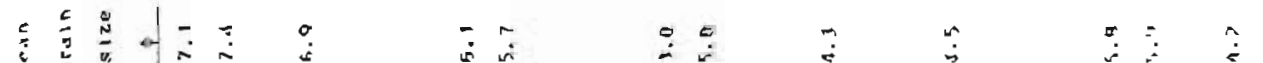

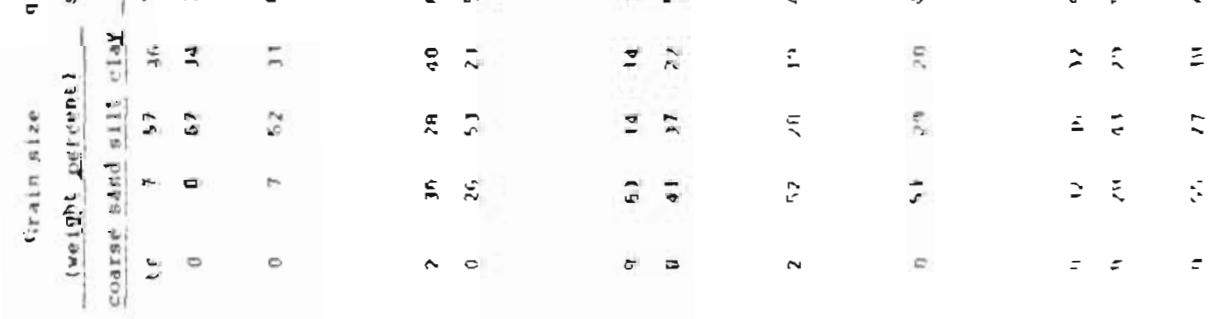

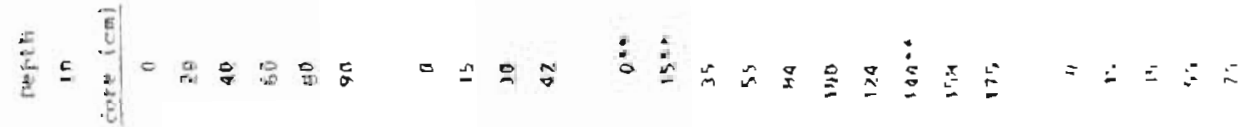

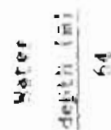

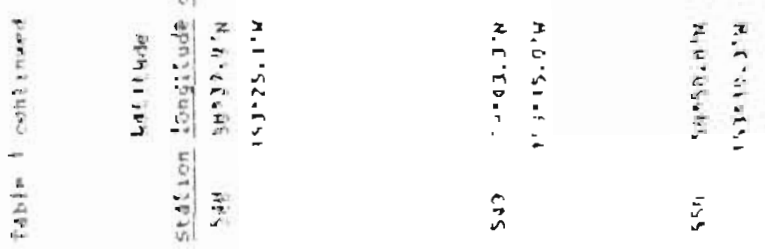
$\therefore$ 


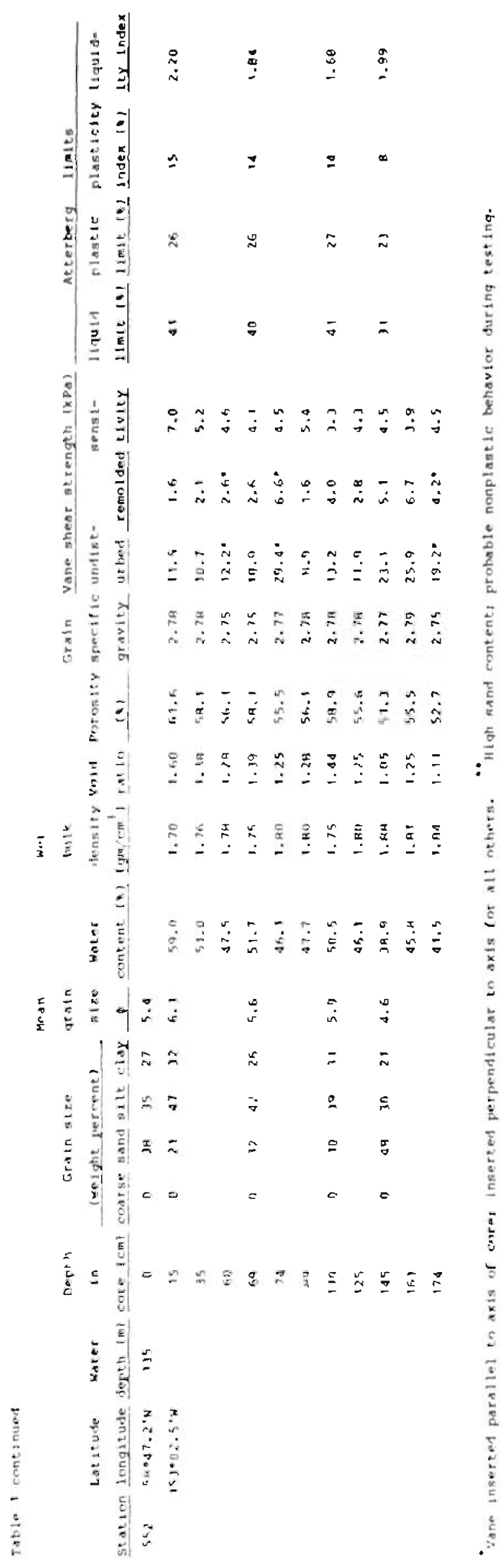


Table 2. Replicate vane shear measurements on split-core halves. $\mathrm{S}_{\mathrm{u}}$ indicates unoisturbed strength, $s_{r}$ indicates remolded strength, subscript 1 refers to first core hale, subscript 2 refers to second. $V_{u}$ and $V_{r}$ are the coefficients of variation for replicate undisturbed and remolded strength measurements, respectively. The notation tc-sp indicates that a torque cell was used to measure strength on the first core half and a spring was used on the second, whereas tc-tc indicates that torque-cell measurements were made on both halves.

\begin{tabular}{|c|c|c|c|c|c|c|c|}
\hline \multirow[b]{2}{*}{ Core } & \multirow{2}{*}{$\begin{array}{l}\text { Depth } \\
\text { in core } \\
\text { (cm) }\end{array}$} & \multirow{2}{*}{$\begin{array}{c}S_{\mathrm{u}} \\
(\mathrm{kPa}) \\
\end{array}$} & \multirow{2}{*}{$\begin{array}{c}\mathrm{s}_{\mathrm{u} 2} \\
(\mathrm{kPa}) \\
\end{array}$} & \multirow{2}{*}{$\begin{array}{c}S_{r 1} \\
(k P 2) \\
\end{array}$} & \multirow{2}{*}{$\begin{array}{l}S_{x 2} \\
(k P 2) \\
\end{array}$} & \multirow{2}{*}{$\begin{array}{l}v_{u} \\
(v) \\
\end{array}$} & \multirow{2}{*}{$\begin{array}{l}v_{r} \\
(\varepsilon) \\
\end{array}$} \\
\hline & & & & & & & \\
\hline $508 \mathrm{Gr}$ & 13 & 3.1 & 3.5 & 0.8 & 1.3 & 12 & 48 \\
\hline \multirow[t]{9}{*}{$(\tau c-t c)$} & 35 & 4.9 & 3.2 & 0.9 & 9.2 & 42 & 29 \\
\hline & 55 & 8.2 & 9.5 & 2.1 & 2.5 & 15 & 17 \\
\hline & 75 & 9.0 & 7.3 & 2.6 & 1.8 & 21 & 30 \\
\hline & 110 & 9.0 & 10.0 & 2.6 & 2.6 & 11 & 0 \\
\hline & 130 & 11.6 & 14.8 & 4.0 & 4.7 & 24 & 16 \\
\hline & 153 & 10.8 & 12.4 & 3.5 & 3.5 & 14 & 0 \\
\hline & 170 & 15.7 & 14.3 & 4.2 & 3.9 & 9 & 7 \\
\hline & 190 & 11.4 & 15.6 & 3.2 & 4.1 & 31 & 25 \\
\hline & 210 & 11.1 & 21.6 & 4.0 & 2.6 & 64 & 42 \\
\hline $511 \mathrm{G} 1$ & 15 & 2.6 & 3.22 & 1.4 & 1.6 & 21 & 13 \\
\hline \multirow[t]{9}{*}{$(t c-s p)$} & 65 & 4.5 & 6.0 & 1.6 & 2.4 & 29 & 40 \\
\hline & 85 & 6.2 & $5 \cdot 2$ & 2.1 & 2.5 & 18 & 17 \\
\hline & 105 & 6.8 & 7.5 & 2.8 & 3.3 & 10 & 16 \\
\hline & 125 & 9.7 & 7.8 & 3.1 & 3.0 & 22 & 3 \\
\hline & 145 & 9.4 & 7.8 & 3.4 & 3.6 & 19 & 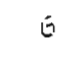 \\
\hline & 165 & 9.9 & 7.8 & 3.3 & 3.3 & 24 & $U$ \\
\hline & 190 & 10.6 & 11.3 & 3.4 & 4.6 & 6 & 30 \\
\hline & 210 & 13.5 & 13.2 & 4.9 & 5.9 & 2 & 19 \\
\hline & 230 & 11.9 & 10.2 & 4.8 & 4.8 & 15 & 0 \\
\hline
\end{tabular}




\begin{tabular}{|c|c|c|c|c|c|c|c|}
\hline Core & $\begin{array}{l}\text { Depth } \\
\text { in core } \\
\text { (cm) }\end{array}$ & $\begin{array}{c}S_{u 1} \\
(k P a)\end{array}$ & $\begin{array}{r}S_{\mathrm{U} 2} \\
(\mathrm{kPa}) \\
\end{array}$ & $\begin{array}{l}{ }_{51} \\
(\mathrm{KP} 2) \\
\end{array}$ & $\begin{array}{r}{ }^{5}{ }^{2} \\
(K P 2)\end{array}$ & $(8)$ & $v_{Y}$ \\
\hline 525 G1 & 15 & 9.5 & 9.5 & 1.6 & 2.6 & 0 & 48 \\
\hline \multirow[t]{7}{*}{$(t c-t c)$} & 35 & 23.5 & 10.5 & 5.4 & 3.7 & 76 & 37 \\
\hline & 55 & 31.3 & 19.4 & 5.6 & 5.1 & 47 & $y$ \\
\hline & 85 & 27.8 & 24.0 & 6.6 & 0.5 & 15 & 2 \\
\hline & 105 & 17.1 & 17.4 & 3.3 & 4.9 & 2 & 19 \\
\hline & 125 & 11.5 & 11.4 & 3.2 & 4.0 & 1 & 22 \\
\hline & 145 & 20.2 & 17.4 & 3.9 & 4.0 & 15 & 3 \\
\hline & 165 & 35.7 & 28.1 & 8.3 & 7.5 & 24 & 100 \\
\hline $526 \quad 62$ & 20 & 7.1 & 7.5 & 2.0 & 2.3 & 5 & 11 \\
\hline \multirow[t]{7}{*}{$(\tau c-5 p)$} & 40 & 11.5 & 7.9 & 3.3 & 2.3 & 37 & 36 \\
\hline & 65 & 7.6 & 9.3 & 2.3 & 2.5 & 20 & 8 \\
\hline & 85 & 10.7 & 6.6 & 2.6 & 2.2 & 47 & 17 \\
\hline & 105 & 14.3 & 13.8 & 3.3 & 4.5 & 4 & 31 \\
\hline & 125 & 5.9 & 8.3 & 1.7 & 2.2 & 34 & 26 \\
\hline & 145 & 18.5 & 14.4 & 4.9 & 4.9 & 25 & 0 \\
\hline & 165 & 11.0 & 4.9 & 3.0 & 2.2 & 77 & 31 \\
\hline
\end{tabular}




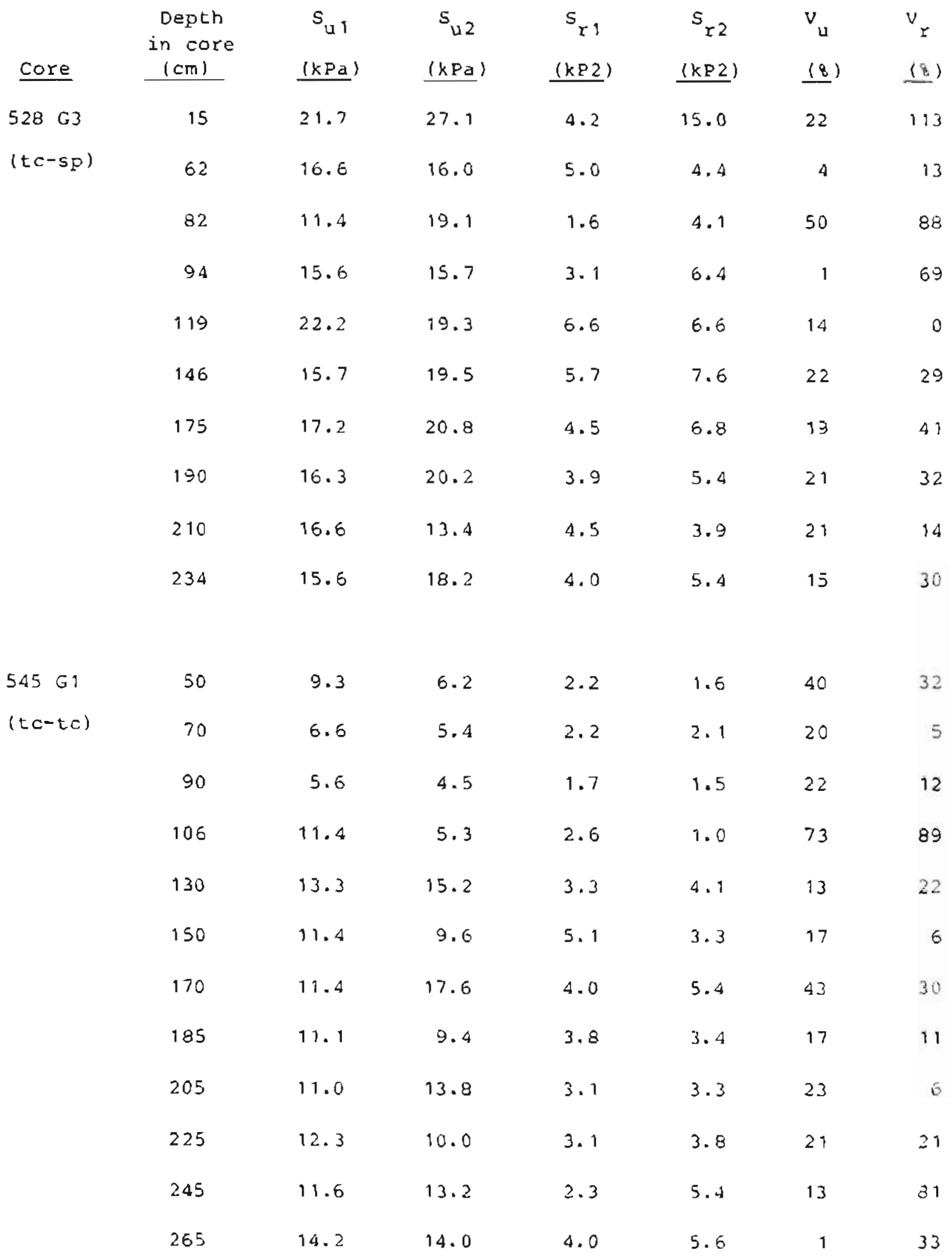




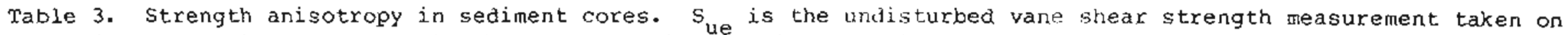

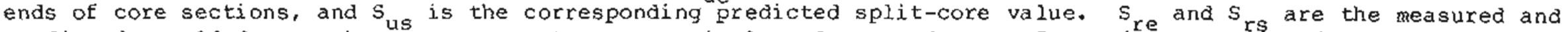

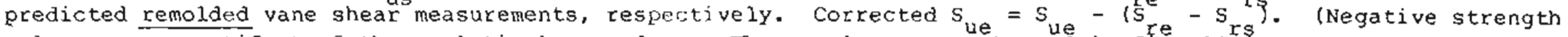
values are an artifact of the analytical procedure. These values are not used in Fig. 11 .

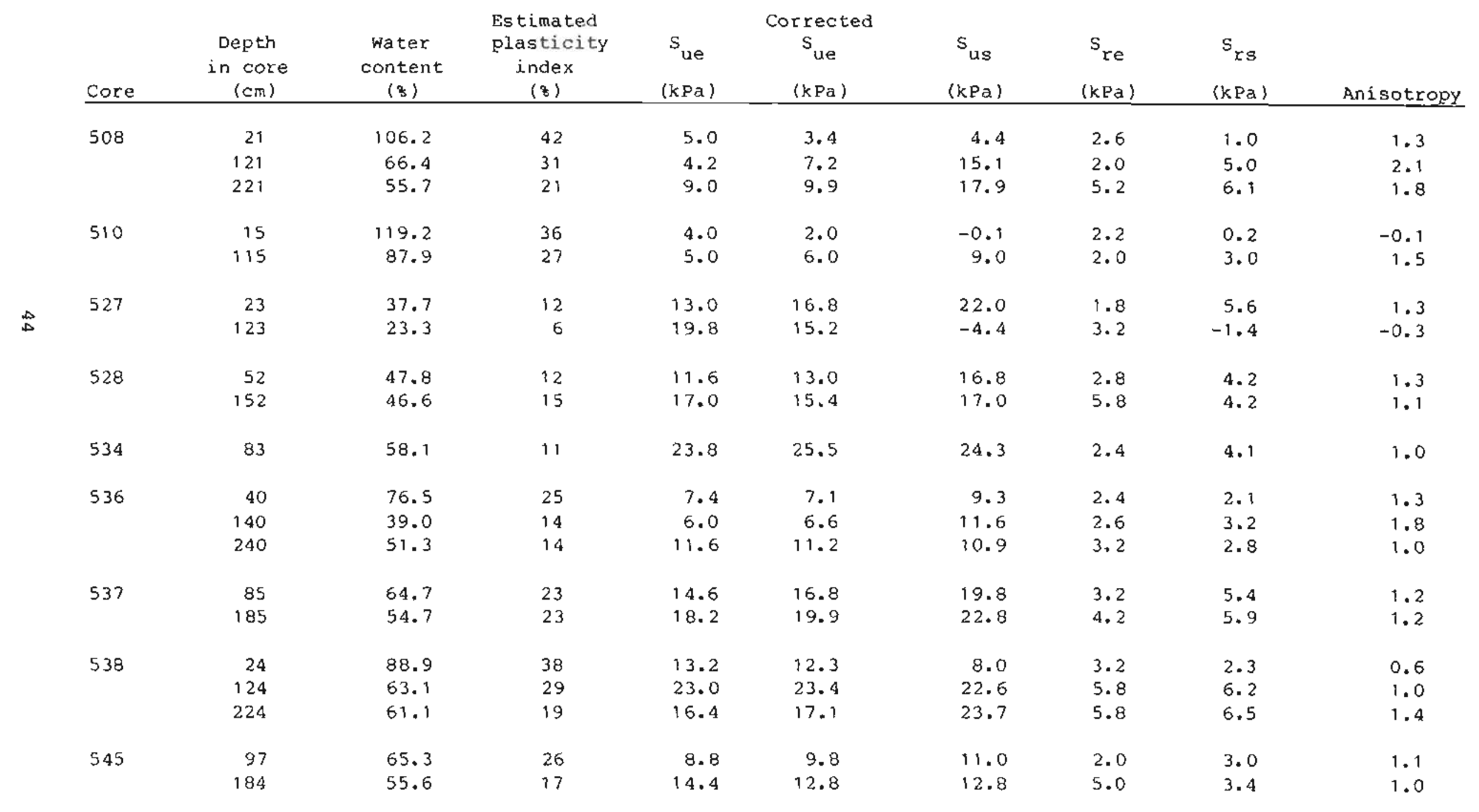


Table 3 cont.

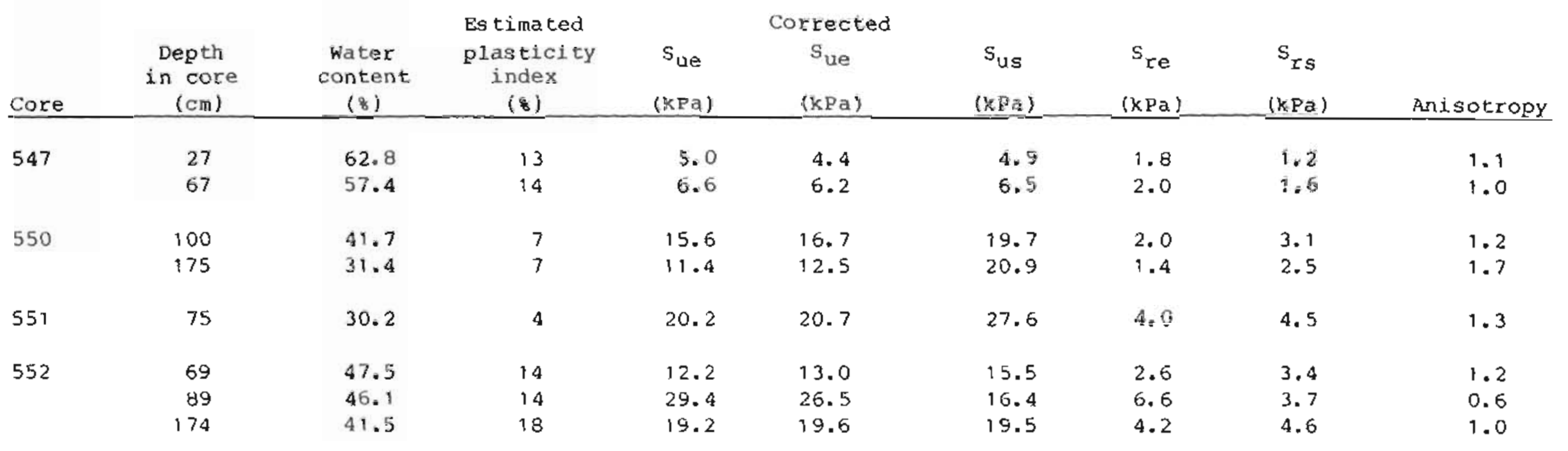




$\begin{array}{rrrrrrr}525 & 38 & 56 & 6 & 75 & 5 & 57 \\ 526 & 45 & 48 & 7 & 79 & 6 & 49 \\ 527 & 37 & 56 & 7 & 79 & 6 & 57 \\ 528 & 37 & 56 & 7 & 75 & 5 & 58 \\ 529 & 34 & 54 & 12 & 75 & 9 & 57 \\ 530 & 40 & 47 & 13 & 79 & 10 & 50 \\ 531 & 51 & 42 & 7 & 75 & 5 & 44 \\ 532 & 40 & 49 & 19 & 70 & 13 & 47 \\ 534 & 46 & 48 & 6 & 75 & 5 & 49 \\ 535 & 42 & 29 & 29 & 77 & 22 & 36 \\ 536 & 47 & 46 & 7 & 76 & 5 & 48 \\ 537 & 42 & 49 & 9 & 77 & 7 & 51 \\ 538 & 44 & 50 & 6 & 80 & 5 & 51 \\ 539 & 43 & 48 & 9 & 81 & 7 & 50 \\ 540 & 49 & 44 & 7 & 80 & 6 & 45 \\ 541 & 47 & 47 & 6 & 77 & 5 & 48 \\ 542 & 47 & 47 & 6 & 84 & 5 & 48 \\ 543 & 45 & 44 & 11 & 70 & 8 & 47 \\ 545 & 44 & 48 & 8 & 77 & 6 & 51 \\ 546 & 45 & 48 & 7 & 75 & 5 & 50 \\ 547 & 48 & 46 & 6 & 75 & 5 & 47 \\ 548 & 32 & 60 & 8 & 79 & 6 & 62 \\ 549 & 40 & 54 & 6 & 75 & 5 & 55 \\ 550 & 38 & 56 & 6 & 79 & 5 & 57 \\ 551 & 45 & 50 & 5 & 75 & 4 & 59 \\ 552 & 35 & 58 & 73 & 82 & 9 & 54 \\ 553 & 37 & 53 & 10 & 91 & 5\end{array}$


Table 5. Clay mineralogy (percents) of shelikof strait and possible source areas.

$\begin{array}{llll}\text { Shelikof strait } & \text { Cook Inlet } & \text { Kodzak Shelf } & \begin{array}{c}\text { Copper River } \\ \text { and Delra }\end{array} \\ \text { average range } & \text { average range } & \text { average range } & \text { average range }\end{array}$

$\begin{array}{lccccccrr}\text { chlorite } & 42 & 32-51 & 42 & 29-64 & 51 & 30-69 & 56 & 53-64 \\ \text { illite } & 52 & 36-66 & 46 & 32-61 & 34 & 19-43 & 31 & 27-39 \\ \text { smectite } & 6 & 0-22 & 3 & 0-19 & 5 & 0-30 & \text { tr } & 0-1\end{array}$


Table 6. Light hydrocarbon gas contents of sediment cores.

\begin{tabular}{|c|c|c|c|c|c|c|c|c|c|}
\hline Station & $\begin{array}{l}\text { Depth } \\
\text { in core } \\
\text { (coll) }\end{array}$ & $\begin{array}{c}c_{1} \\
\text { Methane } \\
(\mu \ell / \ell)\end{array}$ & $\begin{array}{c}\mathrm{C}_{2} \\
\text { Ethane } \\
(\mathrm{n} \ell / \ell)\end{array}$ & $\begin{array}{l}C_{2: 1} \\
\text { Ethene } \\
(n \ell / \ell)\end{array}$ & $\begin{array}{c}\mathrm{C}_{3} \\
\text { Propane } \\
(\mathrm{n} \ell / 2)\end{array}$ & $\begin{array}{c}1-C_{4} \\
\text { Isobutane } \\
(n \ell / \ell)\end{array}$ & $\begin{array}{c}n-C_{4} \\
n \text {-butane } \\
(n \ell / \ell)\end{array}$ & $\frac{c_{1}}{c_{2}+c_{3}}$ & $\frac{c_{2}}{c_{2.1}}$ \\
\hline 509 & $100-110$ & 177 & 228 & 248 & 224 & 24 & 42 & 390 & 0.9 \\
\hline 511 & $96-106$ & 36 & 46 & 12 & 52 & 0 & 0 & 365 & 3.9 \\
\hline 514 & $30-40$ & 23 & 48 & 28 & 46 & 14 & 0 & 247 & 1.7 \\
\hline 523 & $100-110$ & 10 & 24 & 22 & 44 & 0 & 0 & 156 & 1.1 \\
\hline 525 & $100-110$ & 1 & 0 & 0 & 0 & 0 & 0 & & \\
\hline \multirow[t]{3}{*}{526} & $50-60$ & 18 & 116 & 100 & 116 & 26 & 14 & 80 & 1.2 \\
\hline & $100-110$ & 16 & 36 & 28 & 80 & 18 & 0 & 137 & 1.3 \\
\hline & $200-210$ & 38 & & & 66 & & & & \\
\hline 527 & $100-110$ & 25 & 202 & 300 & 192 & 26 & 24 & 62 & 0.7 \\
\hline 528 & $100-110$ & 1 & 0 & 0 & 76 & 0 & 0 & 13 & \\
\hline \multirow[t]{2}{*}{529} & $100-110$ & 12 & 80 & 84 & 116 & 0 & 24 & 60 & 1.0 \\
\hline & $200-210$ & 48 & 184 & 60 & 96 & 12 & 28 & 172 & 3.0 \\
\hline 534 & $50-60$ & 6 & 88 & 66 & 90 & 22 & 20 & 34 & 1.3 \\
\hline 536 & $100-110$ & 26 & 162 & 102 & 138 & 22 & 0 & 85 & 1.6 \\
\hline 537 & $100-110$ & 62 & 106 & 95 & 82 & 0 & 0 & 330 & 1.1 \\
\hline \multirow[t]{2}{*}{538} & 100-110 & 17 & 130 & 72 & 92 & 0 & 0 & 79 & 1.8 \\
\hline & $200-210$ & 27 & 186 & 88 & 158 & 28 & 26 & 79 & 2.1 \\
\hline 539 & $100-110$ & 1628 & 946 & 58 & 100 & 0 & 0 & 1556 & 16.1 \\
\hline \multirow[t]{2}{*}{540} & $100-110$ & 16 & 224 & 100 & 228 & 24 & 48 & 35 & 2.3 \\
\hline & $204-214$ & 16 & 130 & 72 & 118 & 22 & 26 & 63 & 1.8 \\
\hline \multirow[t]{2}{*}{545} & $100-110$ & 51 & 56 & 48 & 50 & 0 & 0 & 480 & 1.2 \\
\hline & $200-210$ & 83 & 42 & 38 & 34 & 0 & 0 & 1070 & 1.2 \\
\hline 548 & $96-106$ & 28 & 64 & 50 & 0 & 0 & 0 & 244 & 1.3 \\
\hline 549 & $42-51$ & 1 & 0 & 0 & 0 & 0 & 0 & & \\
\hline
\end{tabular}


Table 6 cont.

\begin{tabular}{|c|c|c|c|c|c|c|c|c|c|}
\hline & Depth & $c_{1}$ & $\mathrm{C}_{2}$ & $\mathrm{C}_{2: 1}$ & $c_{3}$ & $i-C_{4}$ & $n-C_{4}$ & $C_{1}$ & $\mathrm{C}_{2}$ \\
\hline Station & $\begin{array}{c}\text { in core } \\
(\mathrm{cm})\end{array}$ & $\begin{array}{l}\text { Me thane } \\
(\mu \ell / \ell)\end{array}$ & $\begin{array}{l}\text { Etnane } \\
(n e / 2)\end{array}$ & $\begin{array}{l}\text { Ethene } \\
(n e / \ell)\end{array}$ & $\begin{array}{l}\text { Propane } \\
(n \ell / \ell)\end{array}$ & $\begin{array}{l}\text { Isobutane } \\
(\pi \ell / \ell)\end{array}$ & $\begin{array}{c}\text { n-butane } \\
\text { (ne/l) }\end{array}$ & $\mathrm{C}_{2}+\mathrm{C}_{3}$ & $\mathrm{C}_{2.1}$ \\
\hline \multirow[t]{2}{*}{550} & $100-110$ & 28 & 64 & 50 & 54 & 0 & 0 & 244 & $1 \cdot 3$ \\
\hline & $200-210$ & 17 & 42 & 26 & 54 & 18 & 24 & 180 & 1.6 \\
\hline 551 & $91-101$ & 30 & 154 & 82 & 126 & 20 & 16 & 107 & 1.9 \\
\hline \multirow[t]{2}{*}{552} & $50-60$ & 18 & 44 & 36 & 36 & 0 & 0 & 231 & 1.2 \\
\hline & $100-110$ & 14 & 24 & 18 & 62 & 0 & 0 & 165 & 0.4 \\
\hline
\end{tabular}




\section{FIGURE CAPTIONS}

1. Location map of the study area in Shelikof strait

2. Tracklines of continuous seismic reflection profiles and locations of sampling stations (numbered). Solid lines represent the 1979 Nekton survey contracted by the USGS Conservation Division, and dashed lines represent the $1980 \mathrm{R} / \mathrm{V}$ S.P. LEE cruise.

3. Bathymetry of shelikof strait, 5-m contour interval. Depths corrected to mean lower low water.

4. Shallow structures. Bold lines represent fault offset of the seafloor (hachures on downthrown side), dashed lines indicate buried faults that offset unconsolidated sediment, and dotted lines indicate uncertain extent of buried faults. Fold axes (from Hoose and whitney, 1980) denoted by narrow lines.

5. Boomer seismic reflection profile showing high-offset faults.

6. Thickness of near-surface sedimentary units of probable pleistocene and younger age. Contour interval: $25 \mathrm{milliseconds}$ of two-way travel tine, except $100 \mathrm{~ms}$ for dotted contours where data are relatively sparse and contours are generalized.

7. Seismic reflection record across marginal channel.

8. Pie-diagrams showing relative abundances of textural classes in sediment samples.

9. Mean grain size of seafloor sediment, in phi-units.

10. Vane shear strength (in kilopascals) at shallowest level measured in core (typically at $15 \mathrm{~cm}$ ) none deeper than $74 \mathrm{~cm}$ ).

11. Anisotxopy of vane ghear strength versus plasticity index, including experimentally derived curve of Bjerrum (1973). Sus is the predicted (from the regression line) value of undisturbed strength measured on a split core, and corrected $S$ ue is the (corrected) value of undisturbed strength measured on an end of core. Both values are hypothetically from the same depth in the core.

12. Sensitivity at shallowest level measured in core (typically at $15 \mathrm{~cm}$; none deeper than $74 \mathrm{~cm}$ ).

13. Water content at shallowest level measured in core (typically at $15 \mathrm{~cm}$; none deeper than $74 \mathrm{~cm}$ ).

14. Liquid limit at shallowest level measured in core (typically at $15 \mathrm{~cm}$; none deeper than $129 \mathrm{~cm}$. 
15. Plastic limit at shallowest level measured in core (typically at $15 \mathrm{~cm}$ none deeper than $129 \mathrm{~cm}$ ).

16. Plasticity index at shallowest level measured in core (typically at $15 \mathrm{~cm}$; none deeper than $129 \mathrm{~cm}$ )

17. Liquid limit versus mean grain size.

18. Plastic limit versus mean grain size.

19. Plasticity versus mean grain size.

20. Plasticity chart.

21. Organic carbon (percent dry weight) in seafloor sediment.

22. Carbonate carbon (percent dry weight) in seafloor sediment.

23. Organic carbon versus grain size.

24. Water content versus organic carbon.

25. Plasticity index versus organic carbon.

26. Shear strength versus organic carbon.

27. Sensitivity versus organic carbon.

28. Liquidity index versus organic carbon.

29. Illite content of seafloor sediment.

30. Chlorite content of seafloor sediment.

31. Mixed-layer clay (mostly smectite) content of seafloor sediment.

32. Locations of acoustic anomalies along tracklines.

33. Uniboom seismic reflection record showing acoustic anomaly over truncated fold in bedrock. Vertical scale is in two-way travel time.

34. Locations of craters along tracklines. Dots represent seafloor craters; circles represent buried craters.

35. Uniboom seismic reflection record showing seafloor and buried craters. Vertical scale is in two-way travel time.

36. Uniboom seismic reflection recoro showing slump mass at base of seafloor escarpment. Vertical scale is in two-way travel time. 


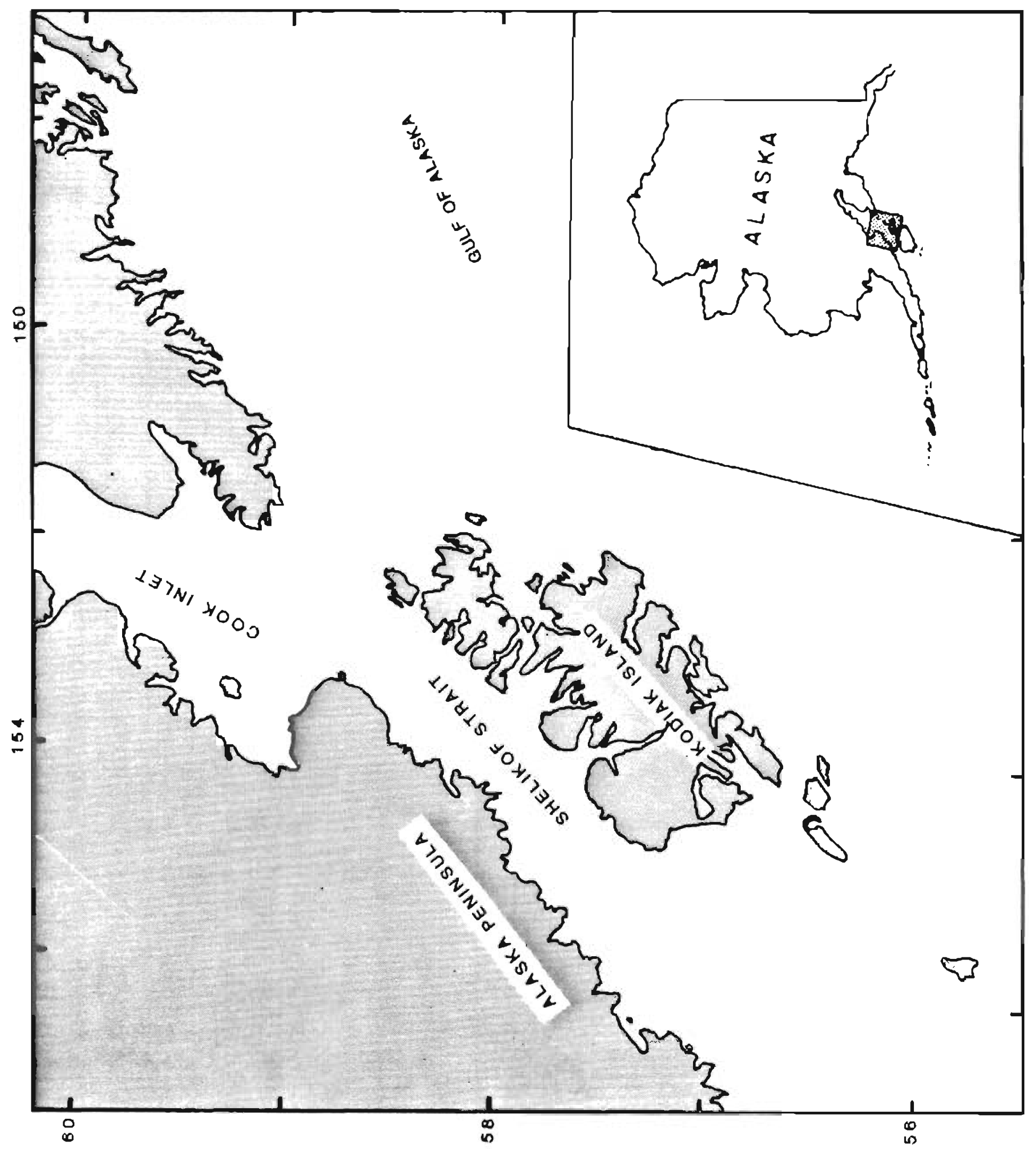

52 


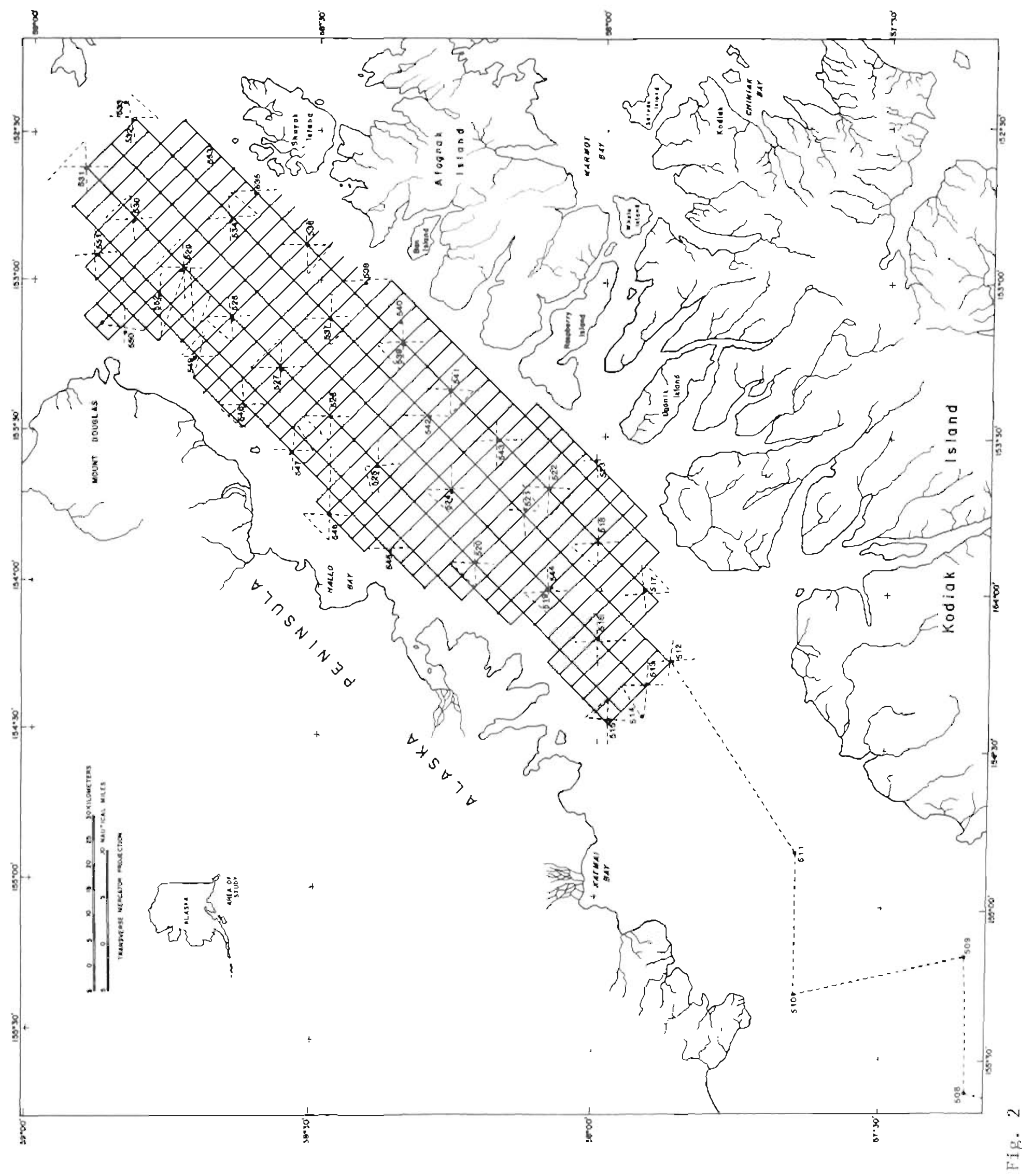




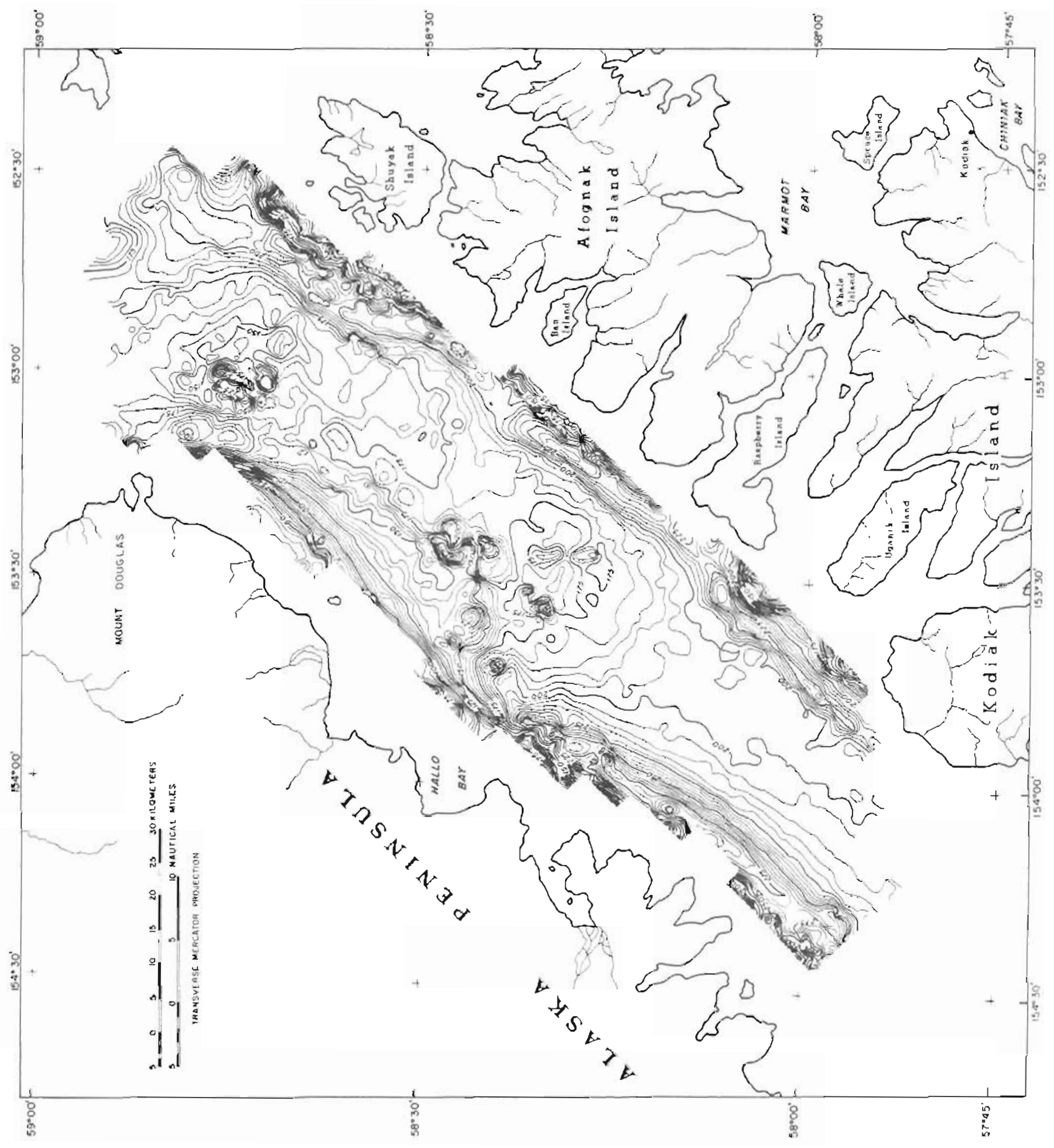

$1)$
0
11
11 


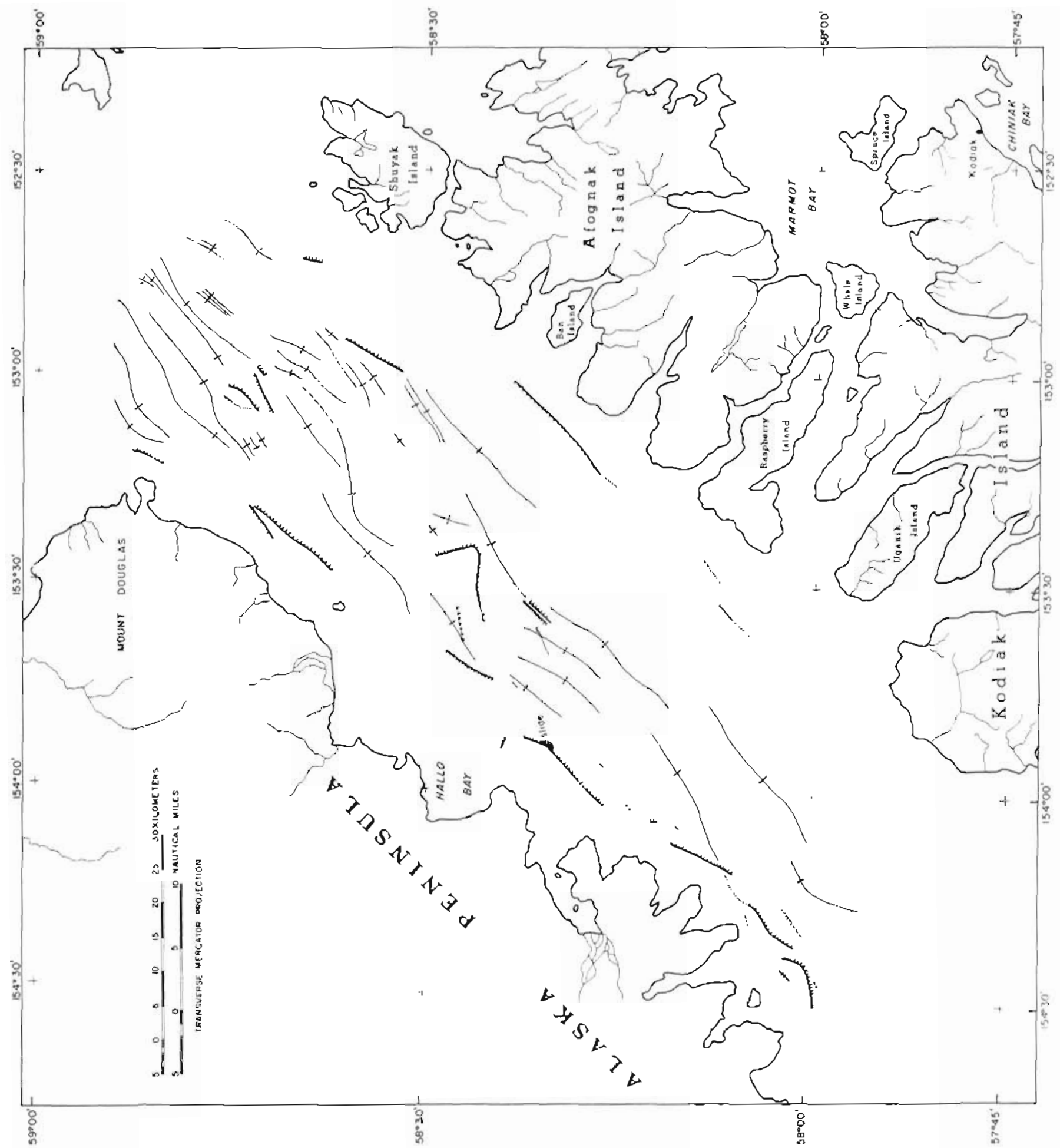

$\therefore$ 

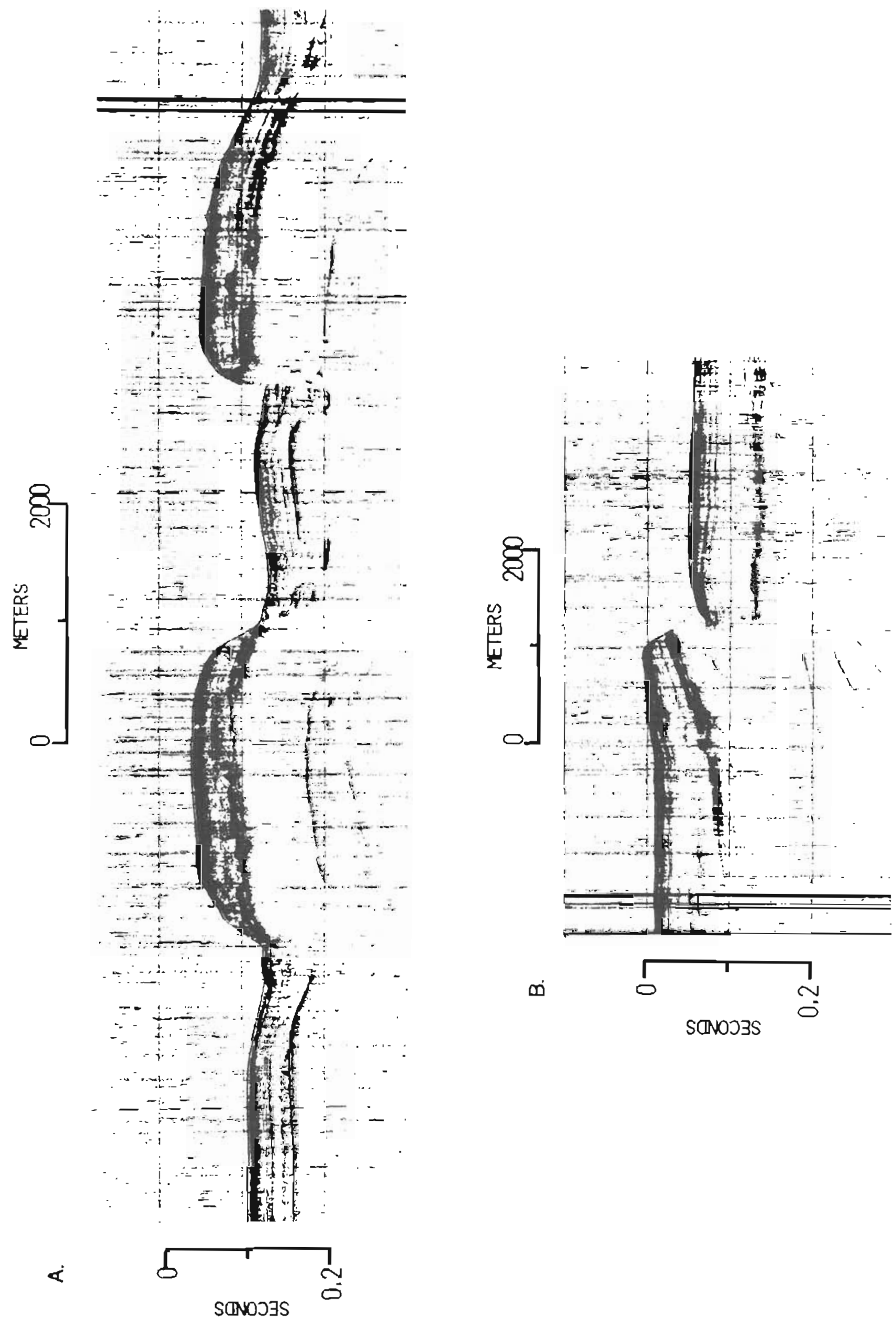


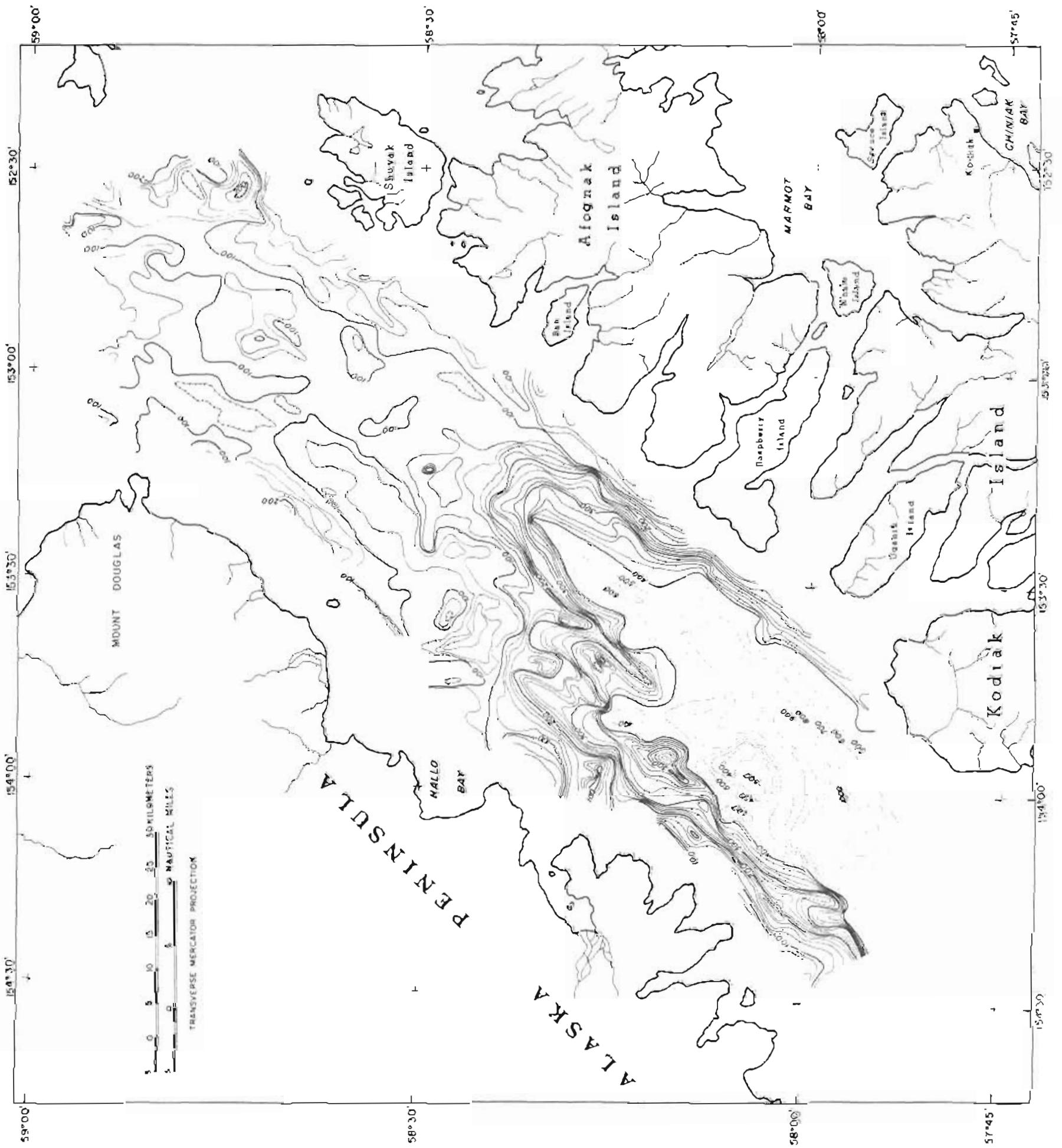

1
0
0
$r-1$ 


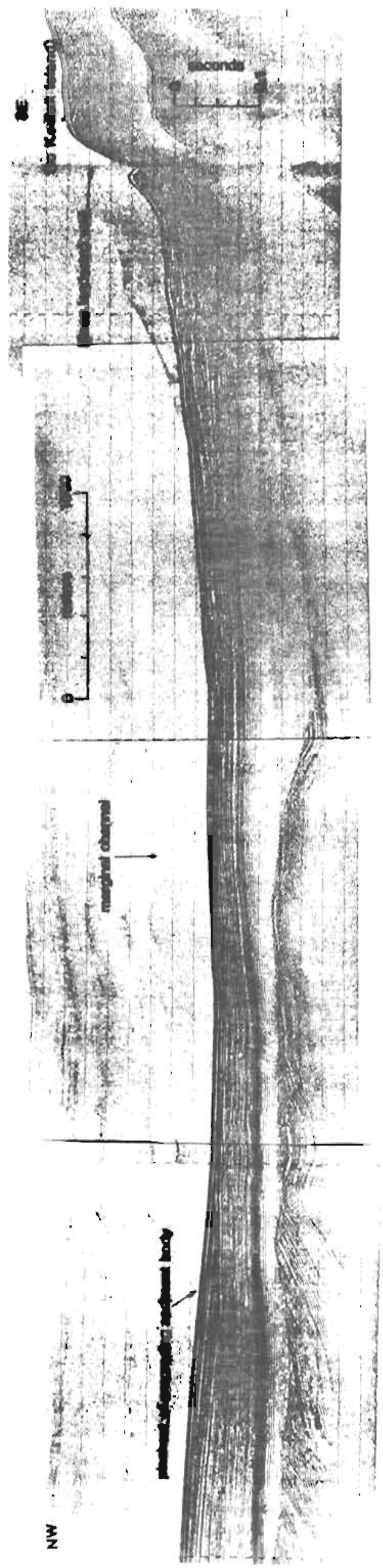

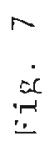




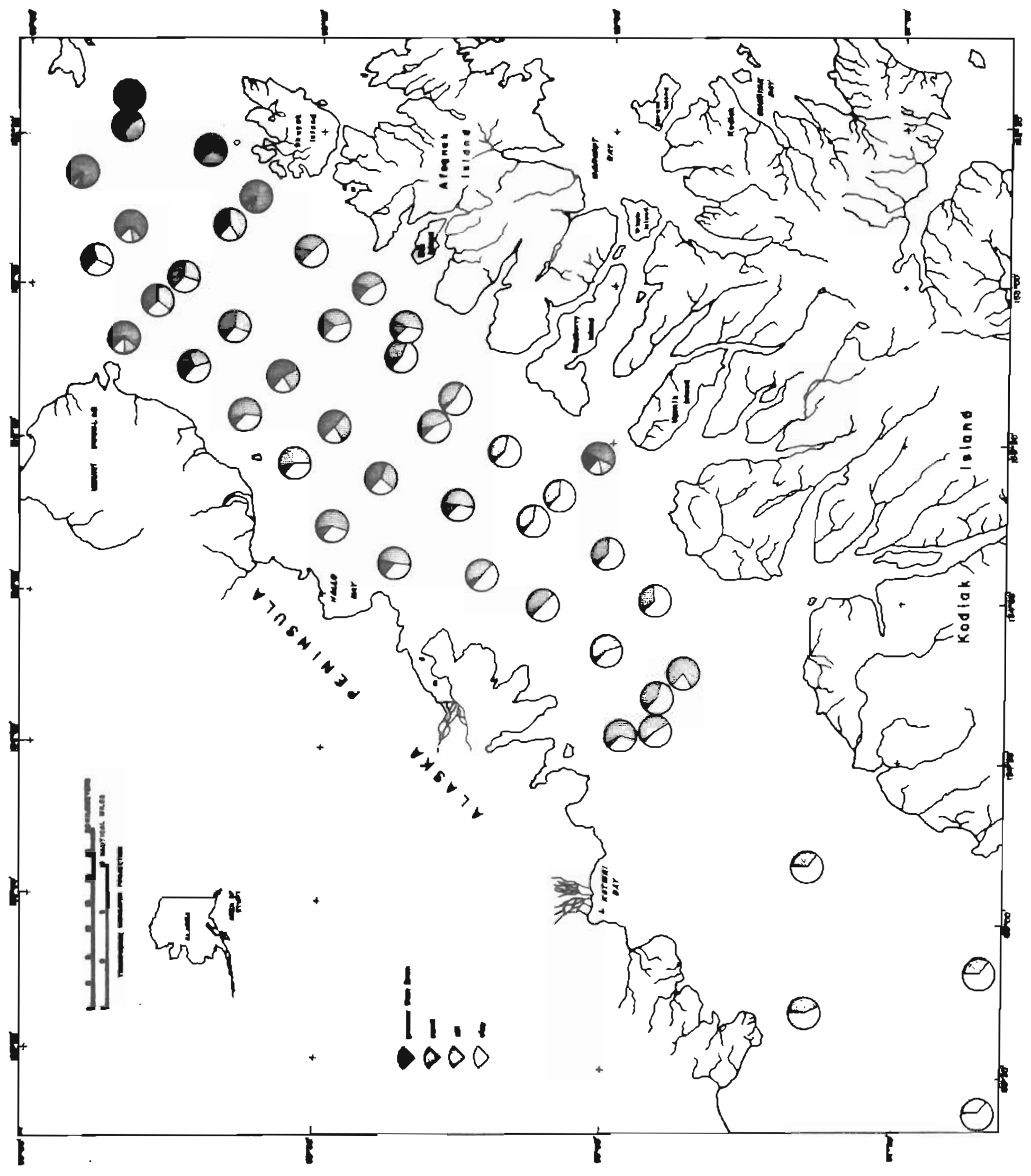




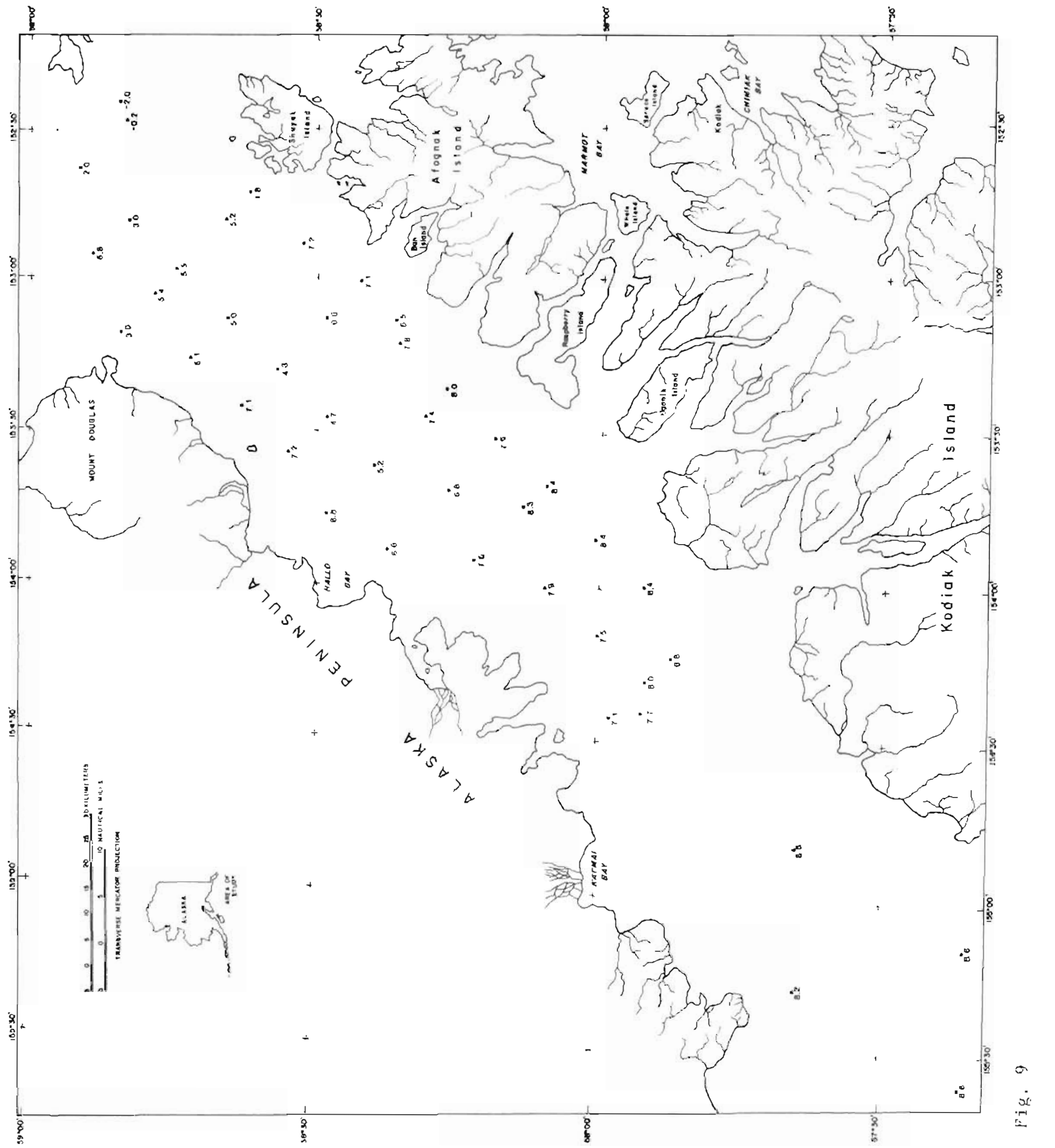




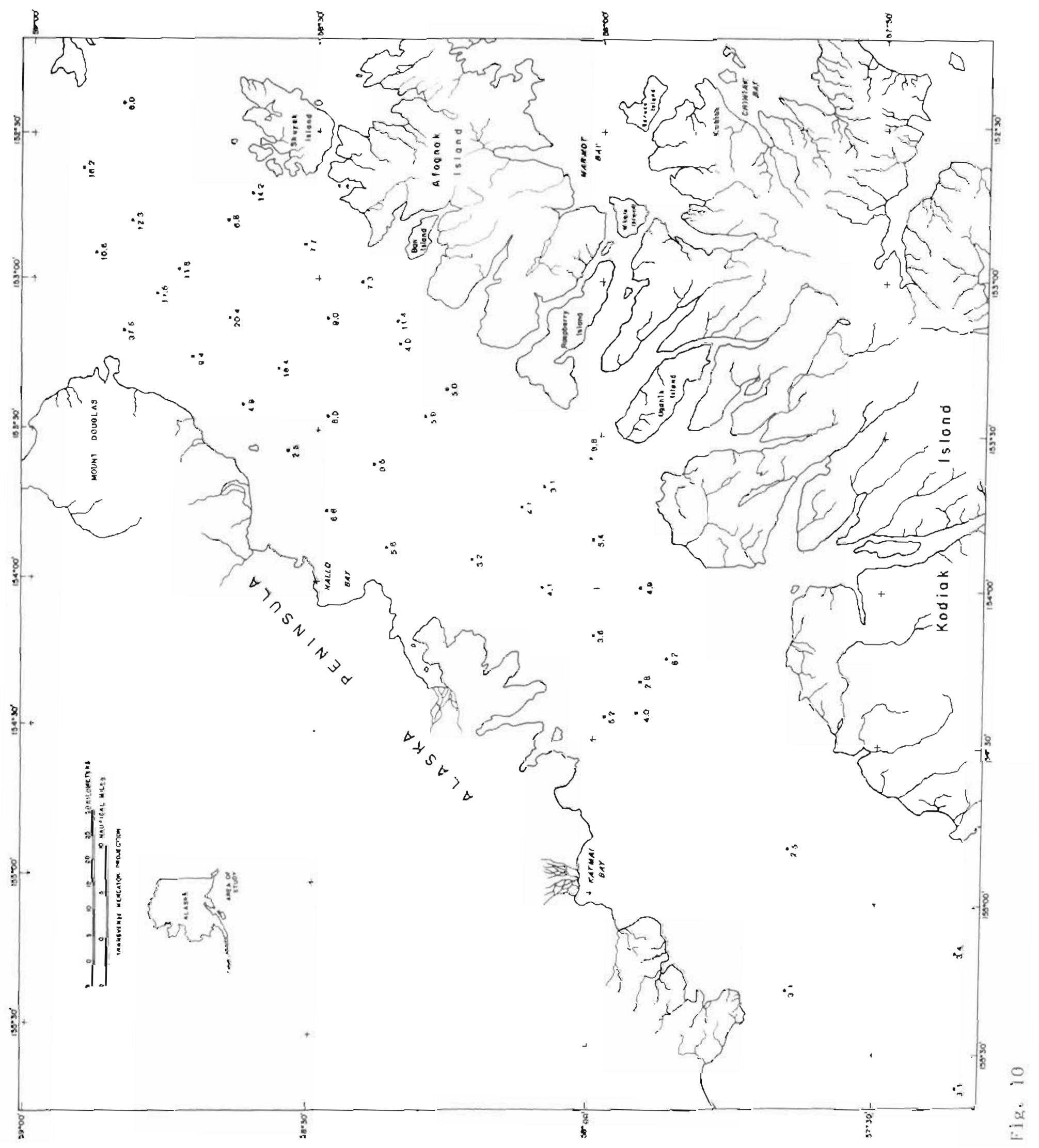




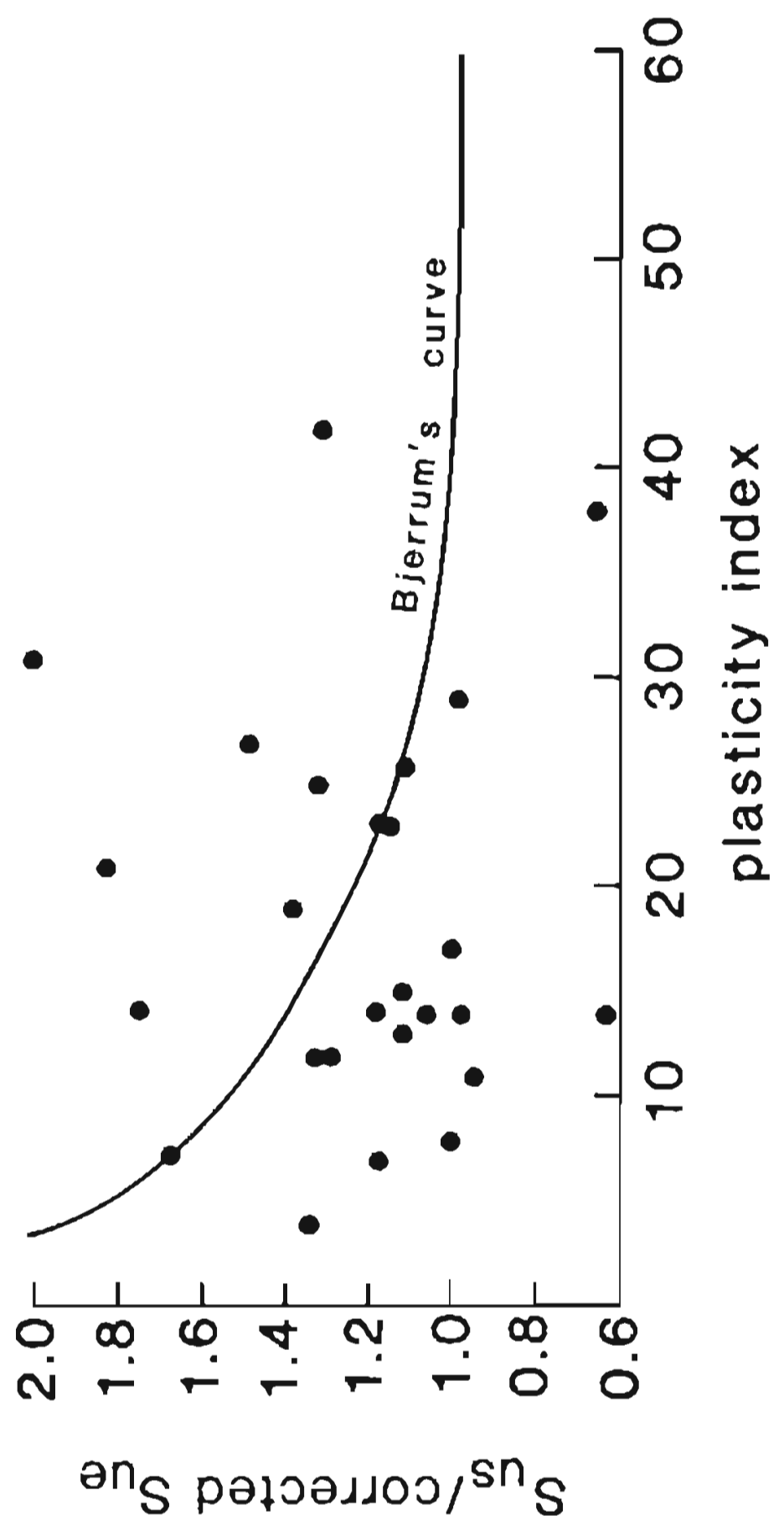




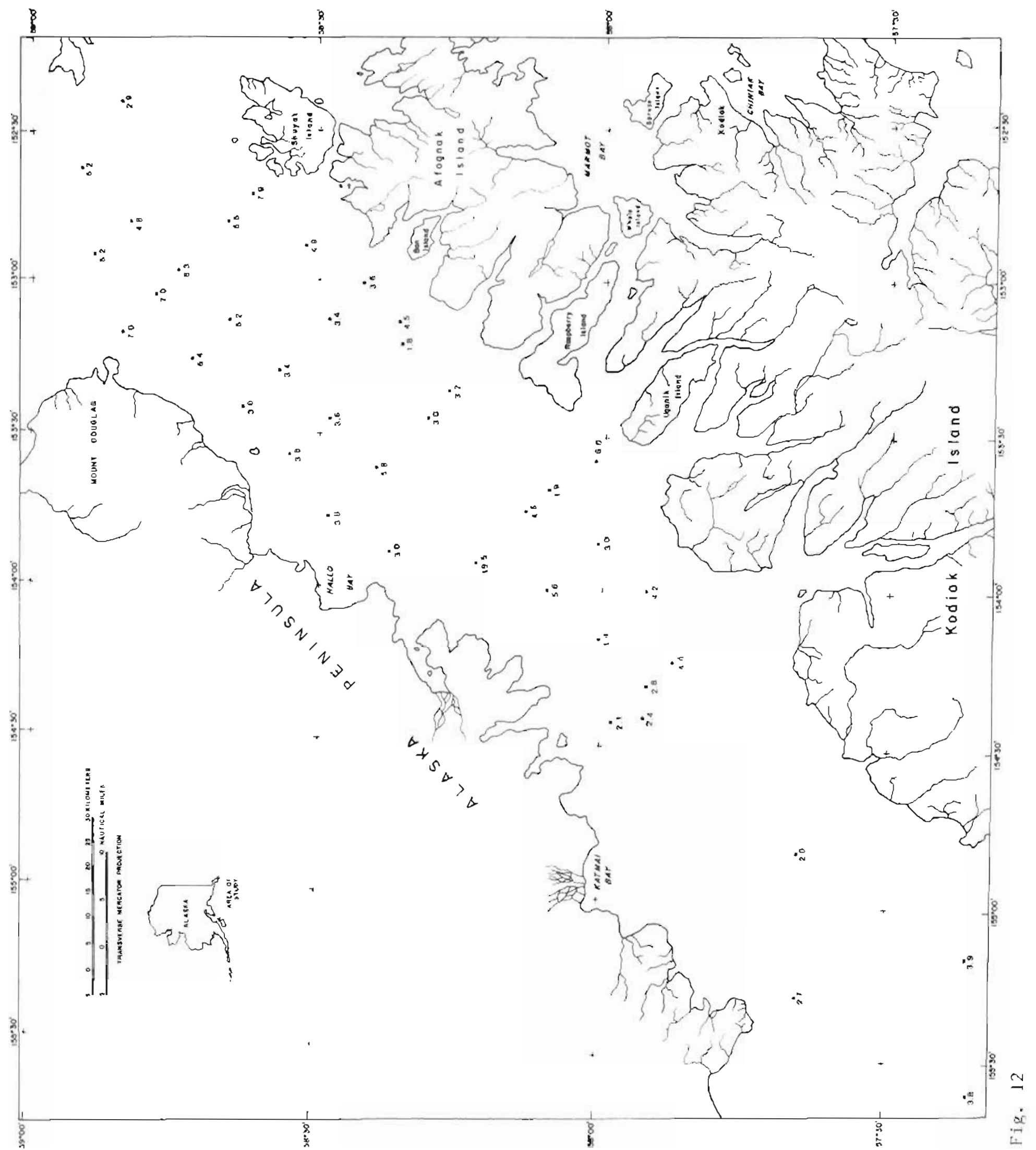




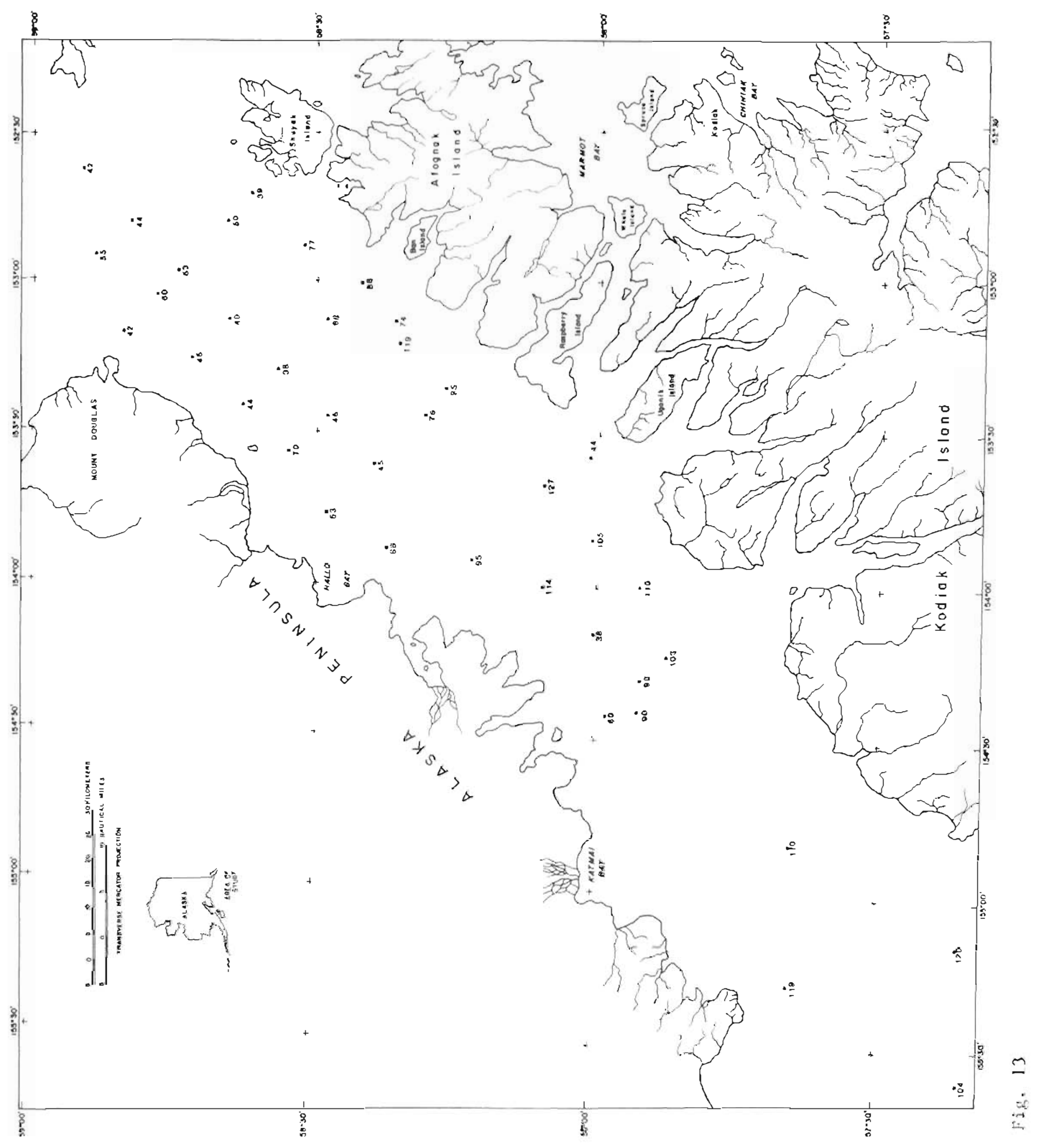




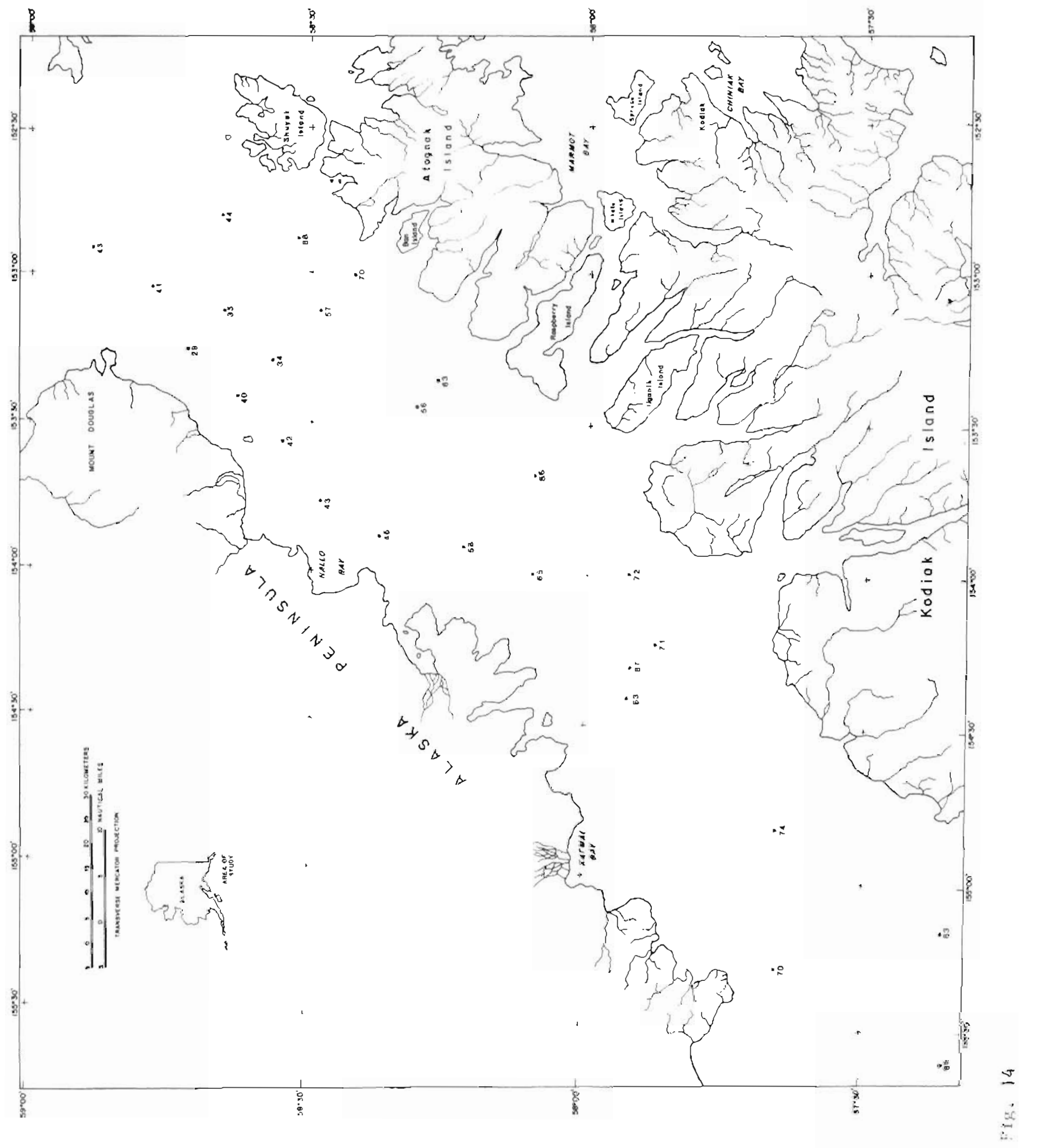




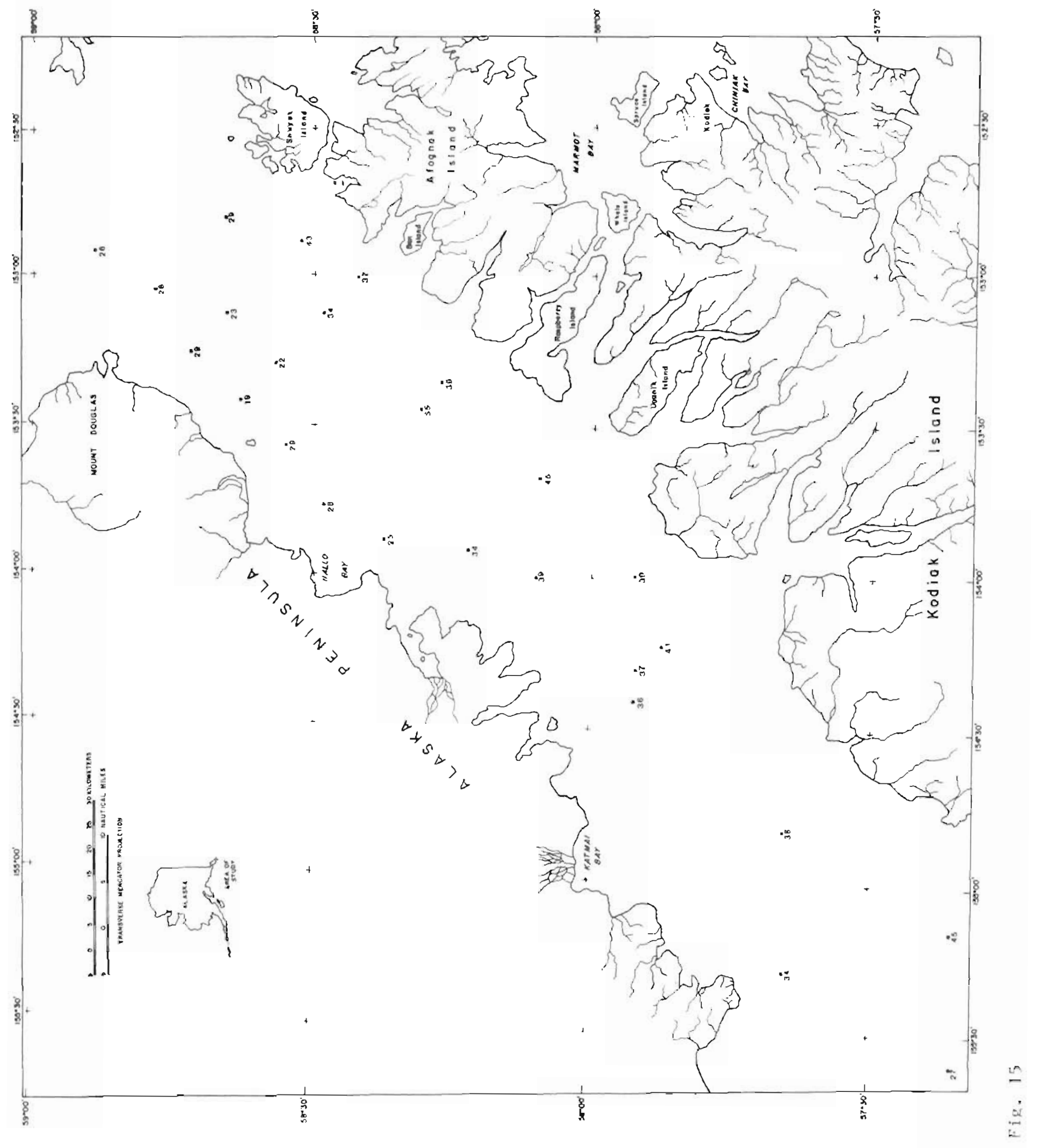




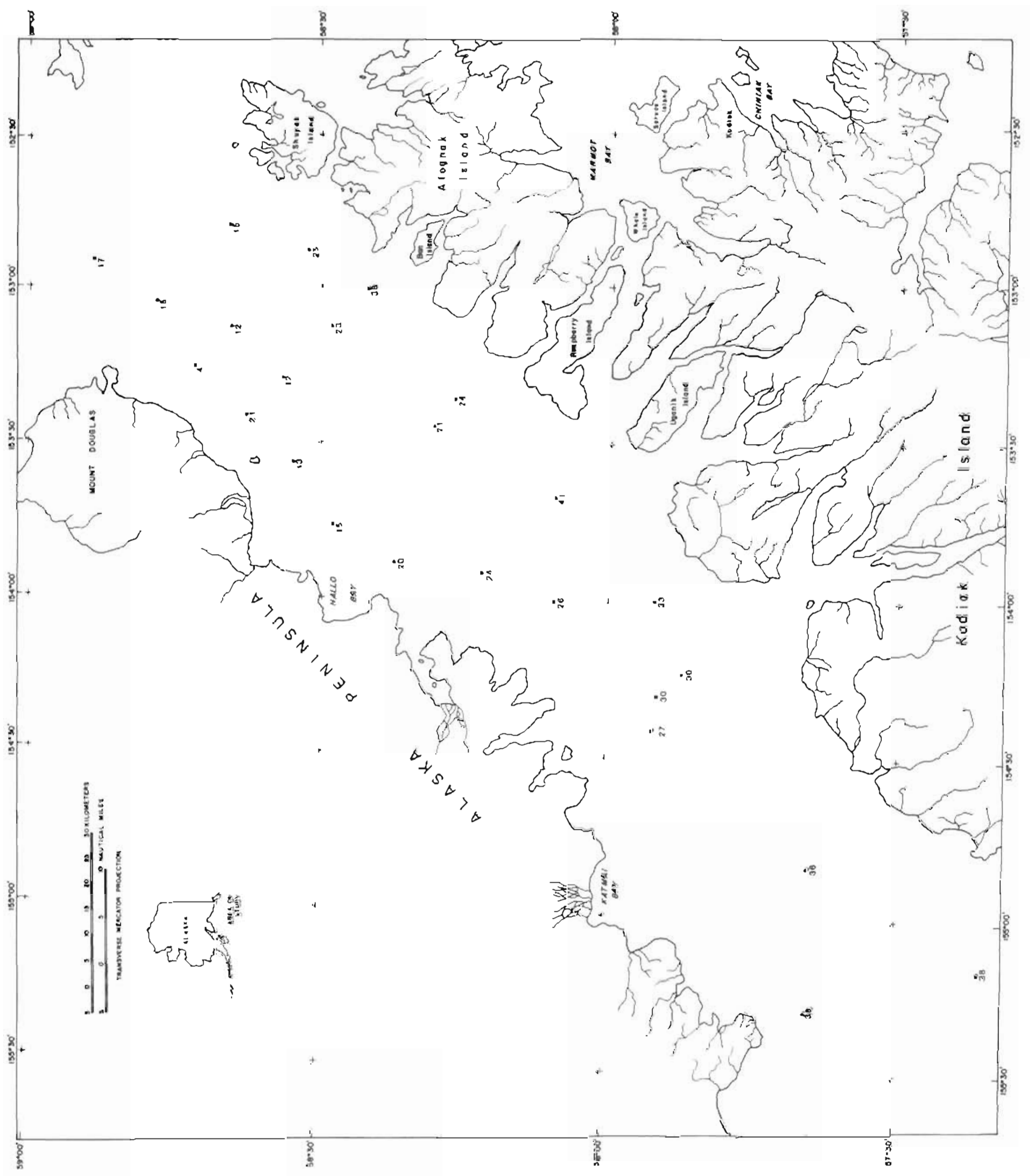

$\simeq$
$\therefore$
$\therefore$ 


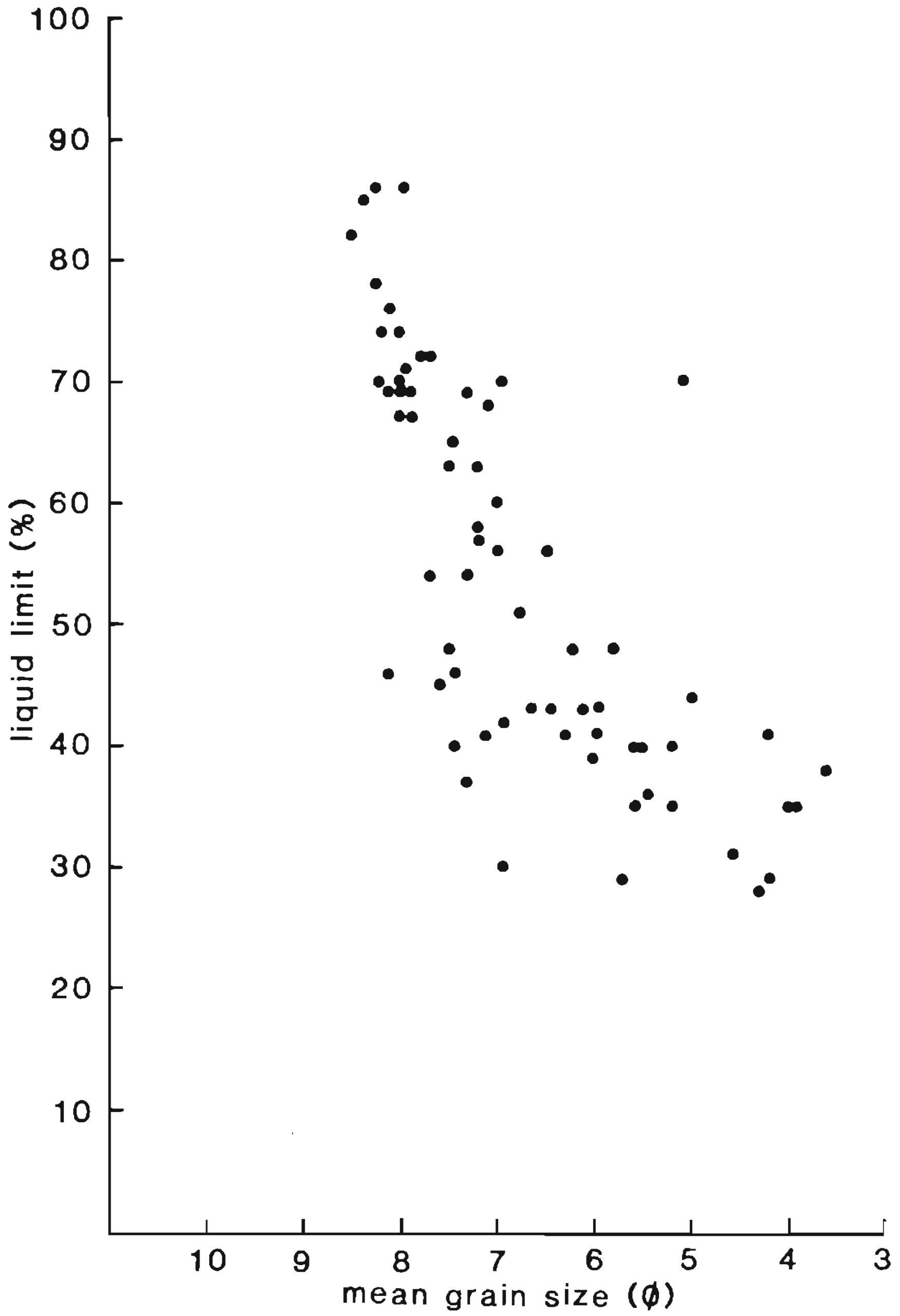




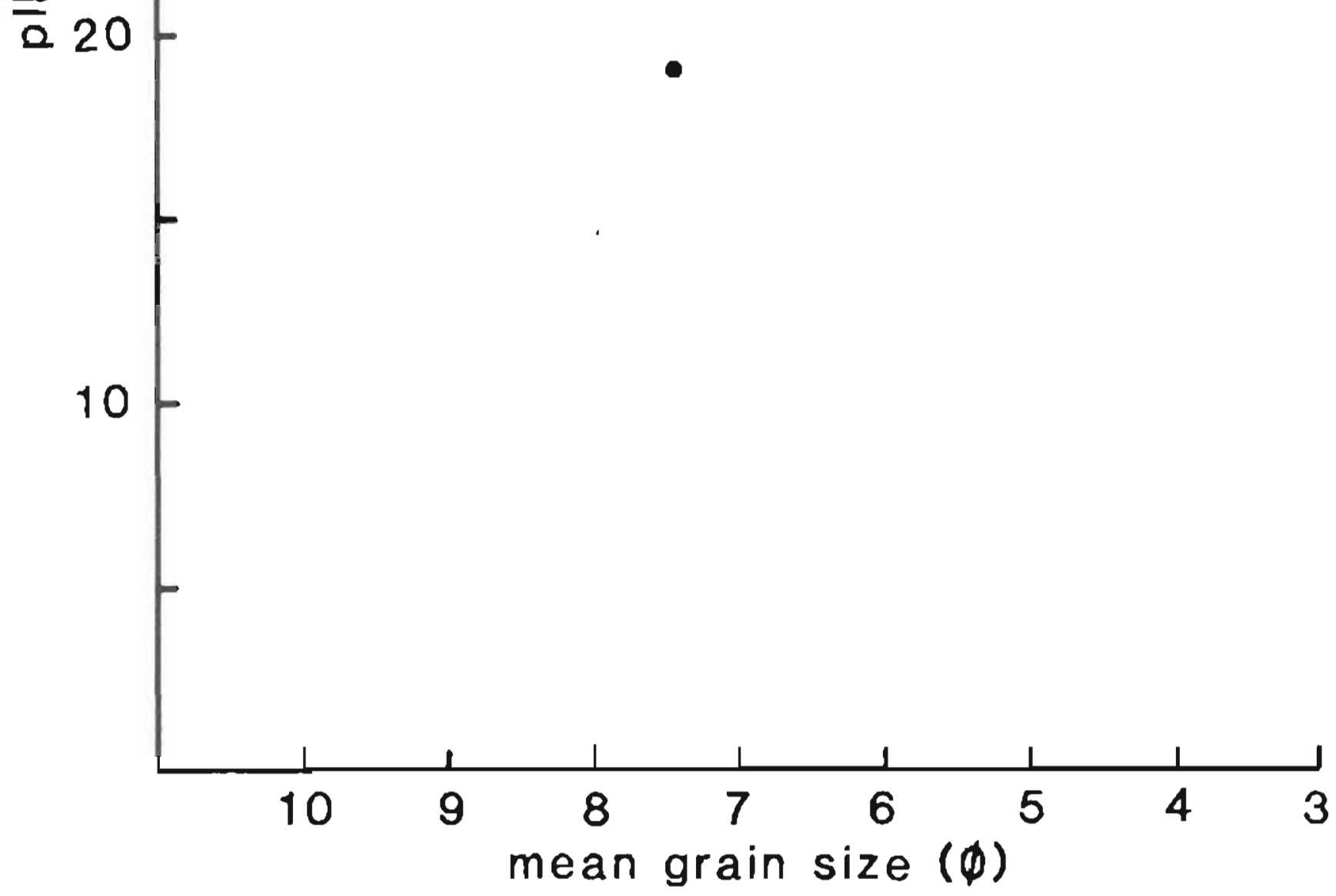

Fig. 18 69

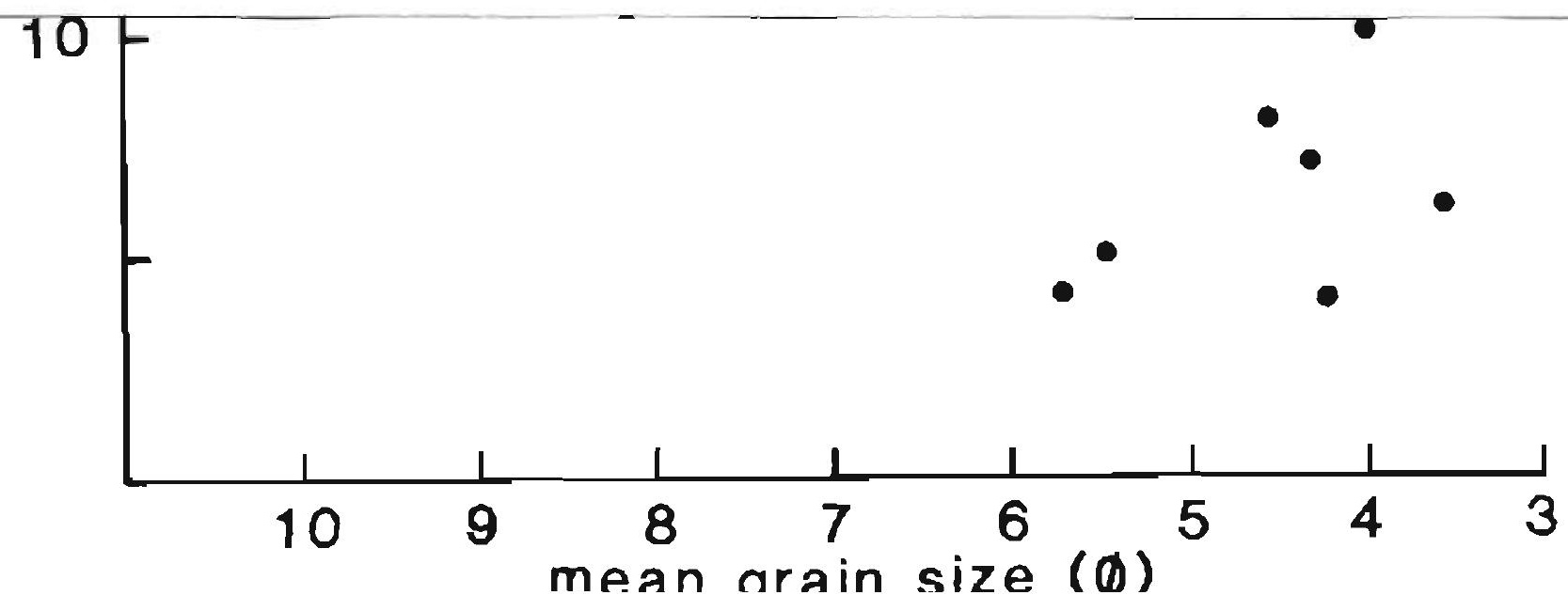




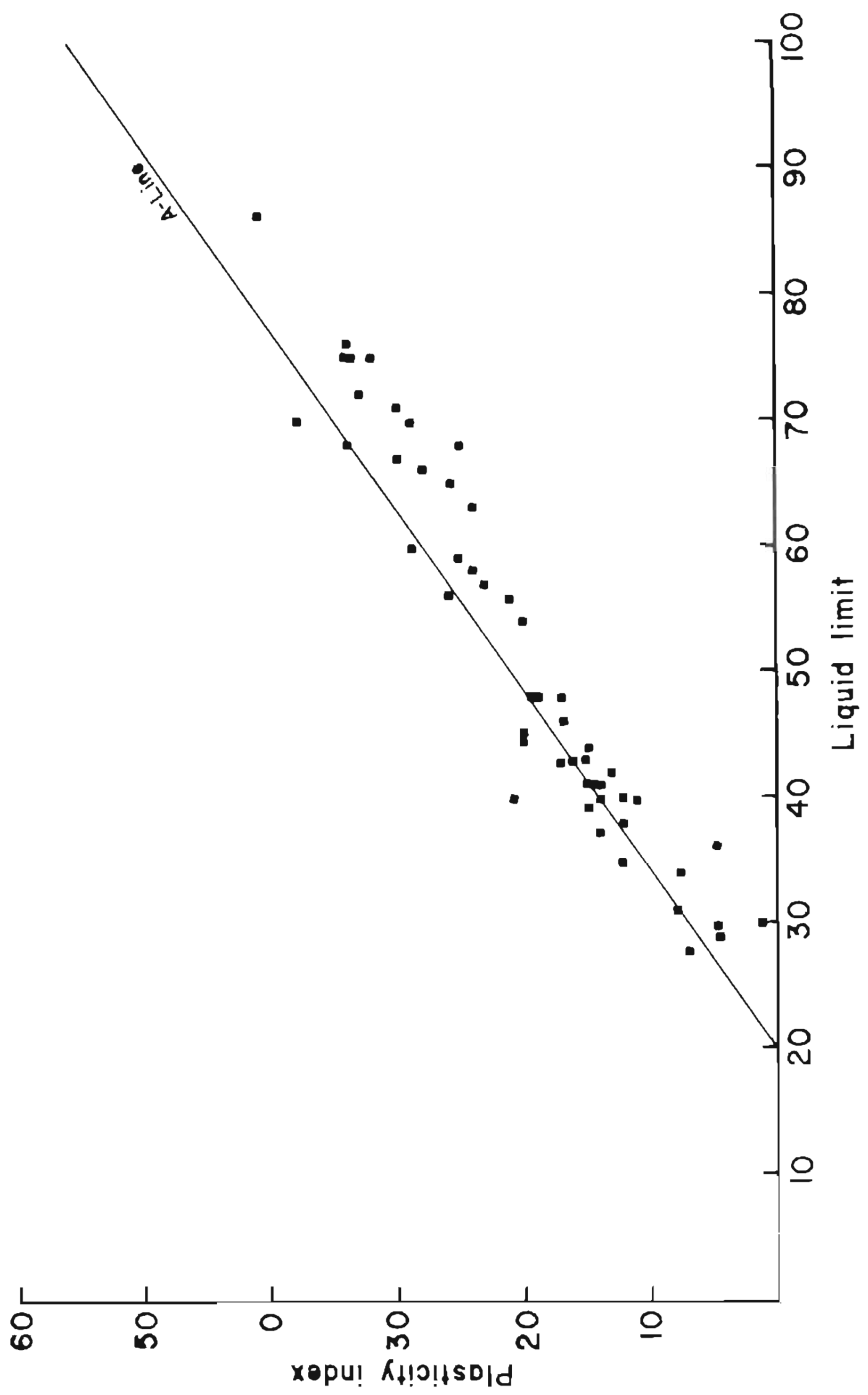




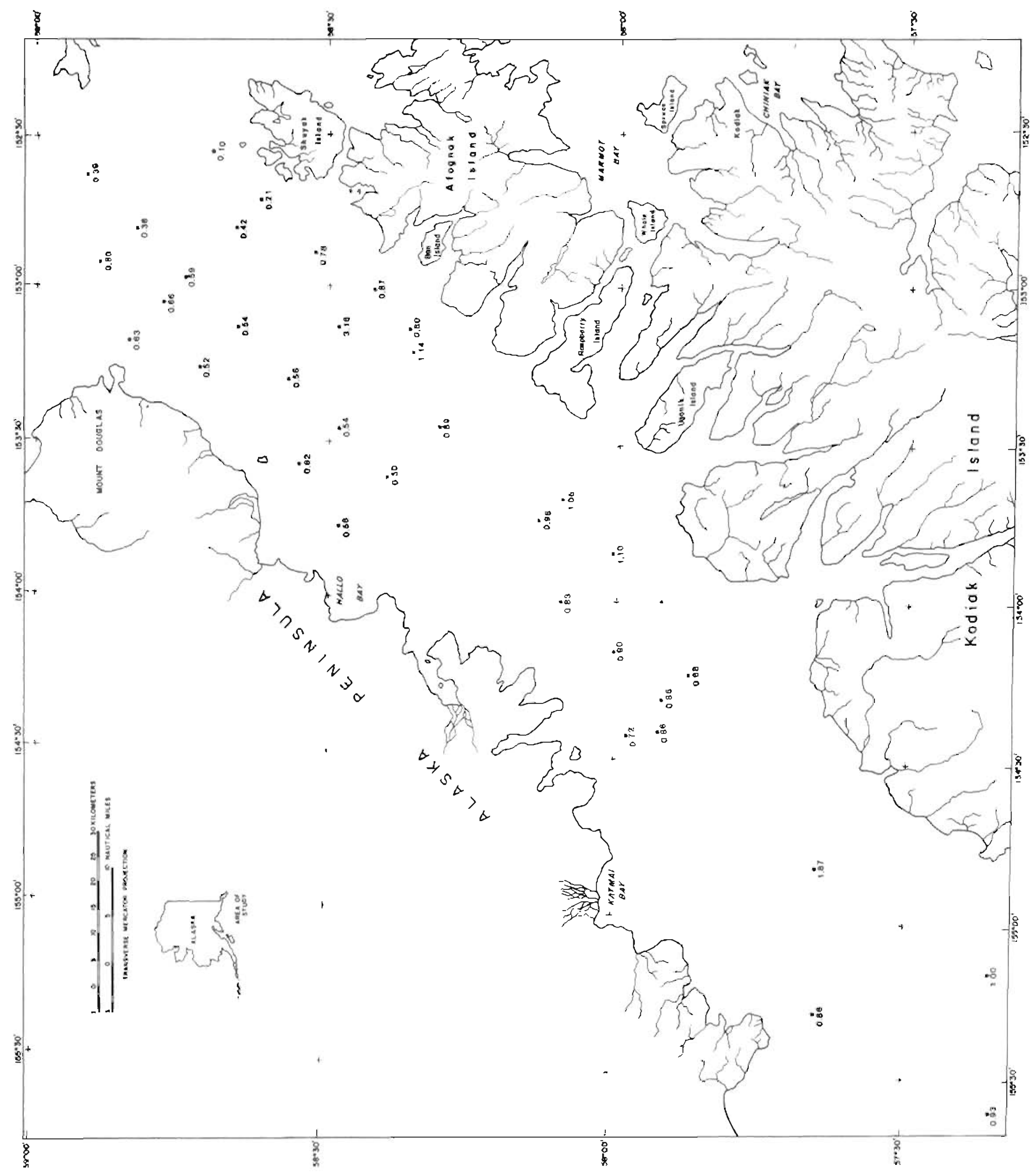

$\underset{-1}{\Delta-1}$ 

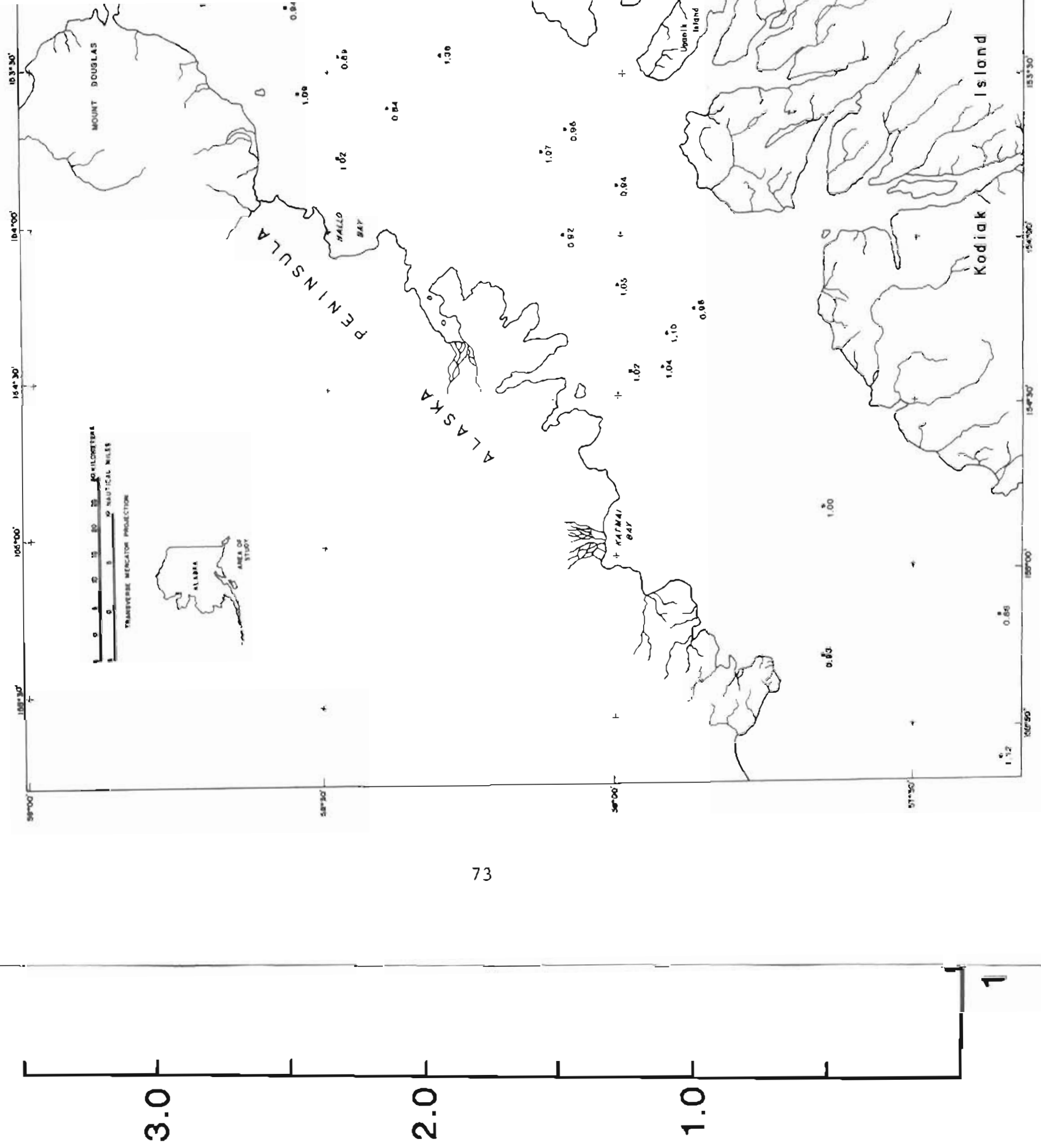

(\%) voqueo o!uebso 


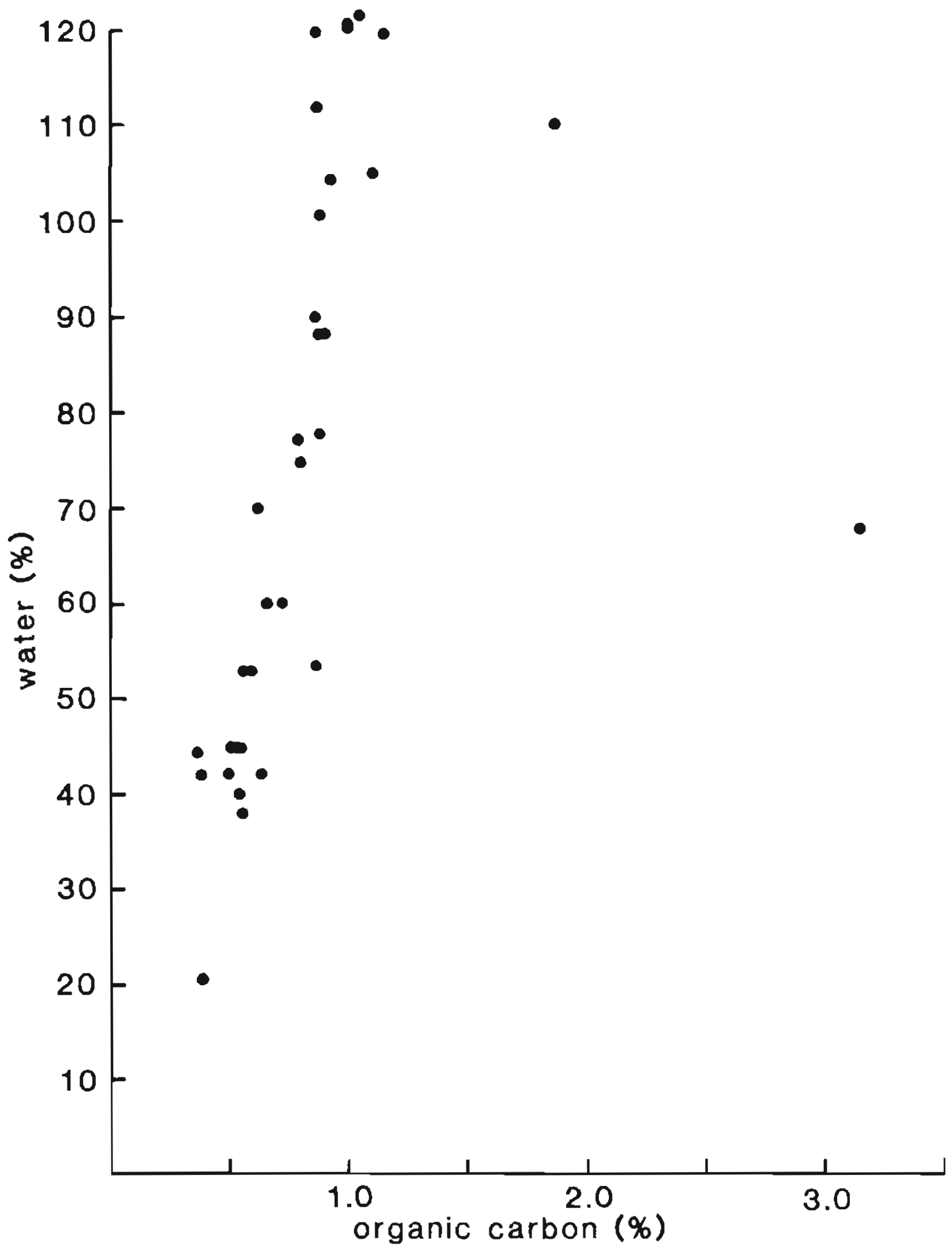

FIg. 24 


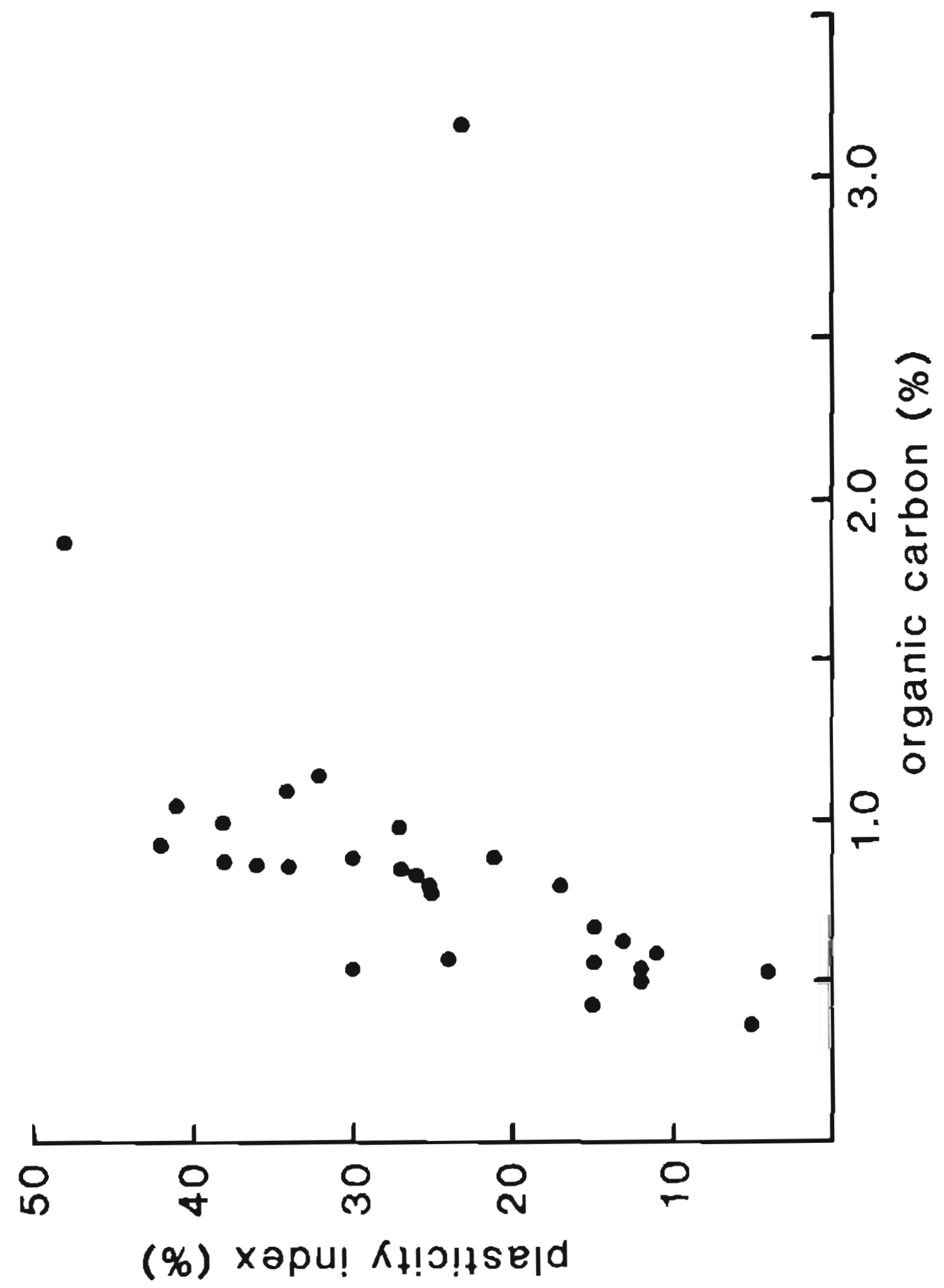




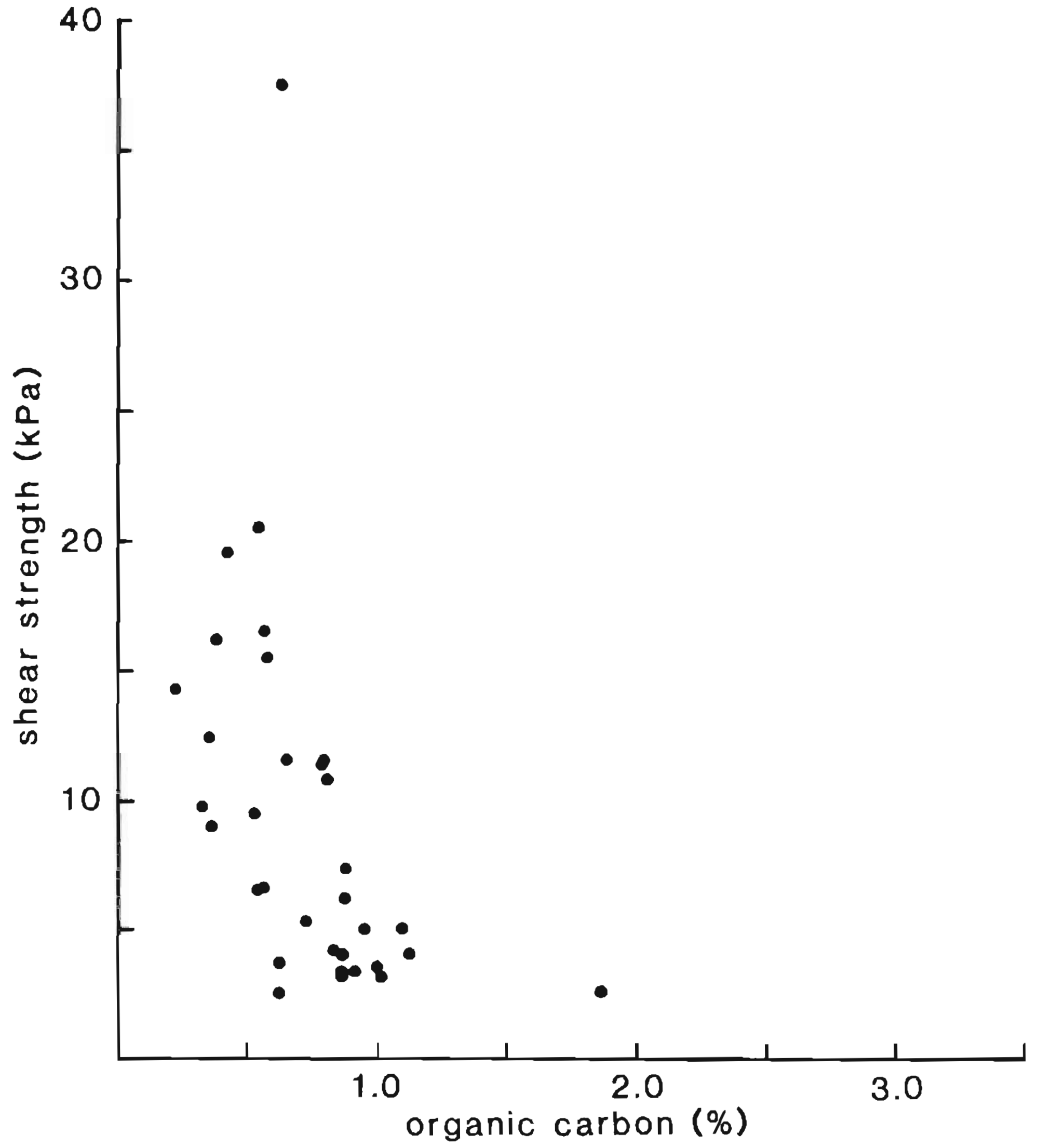




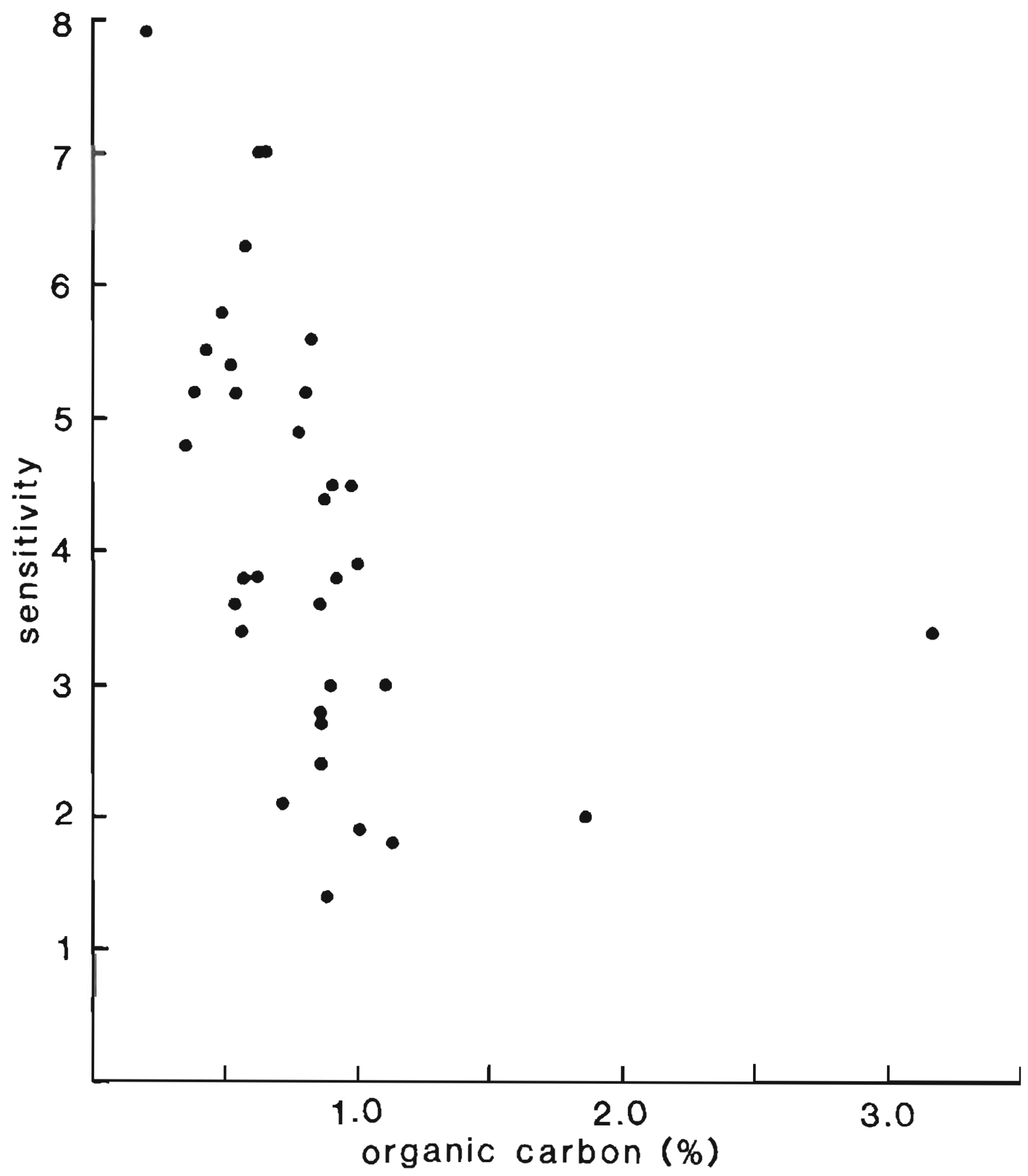




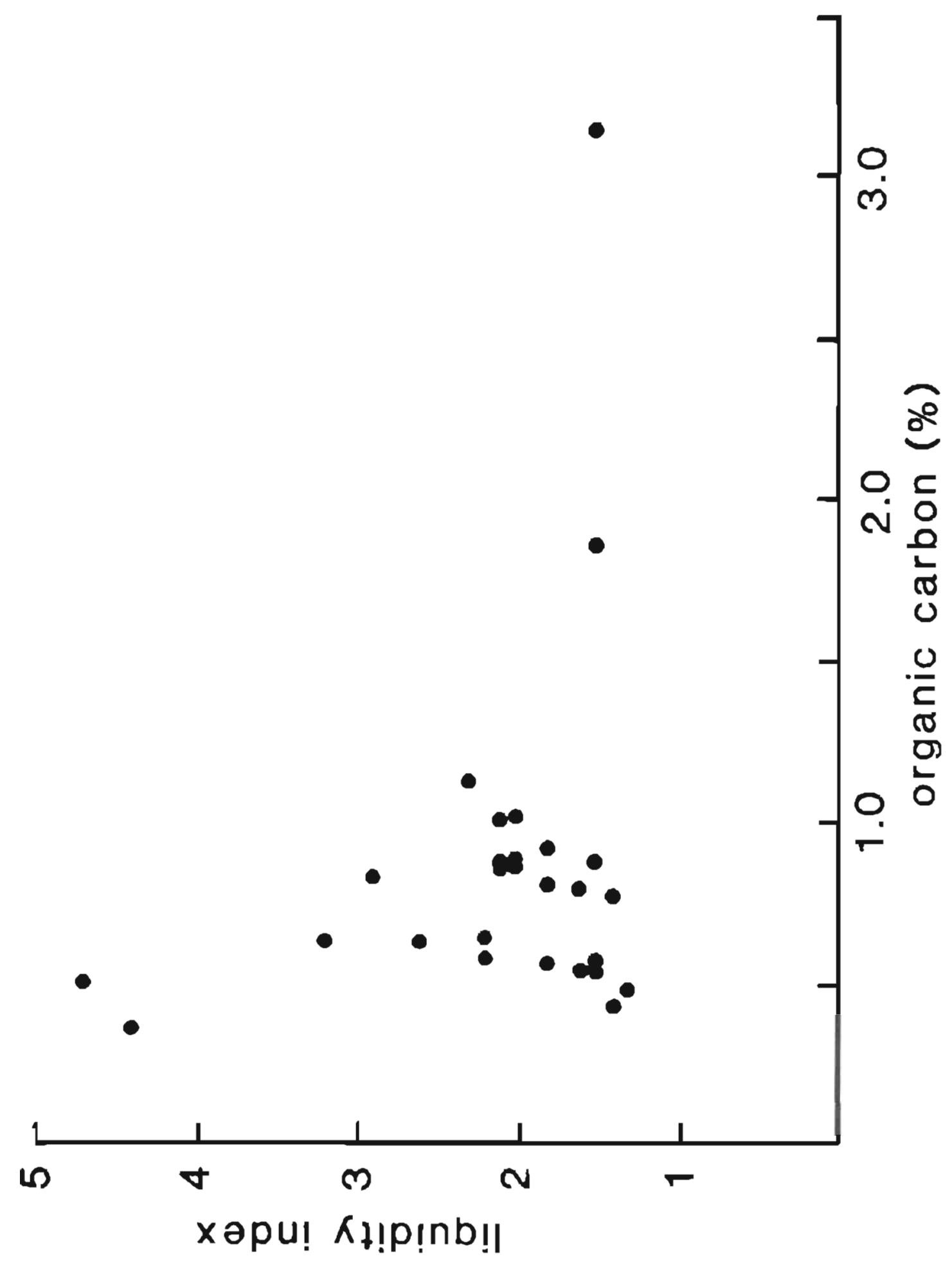




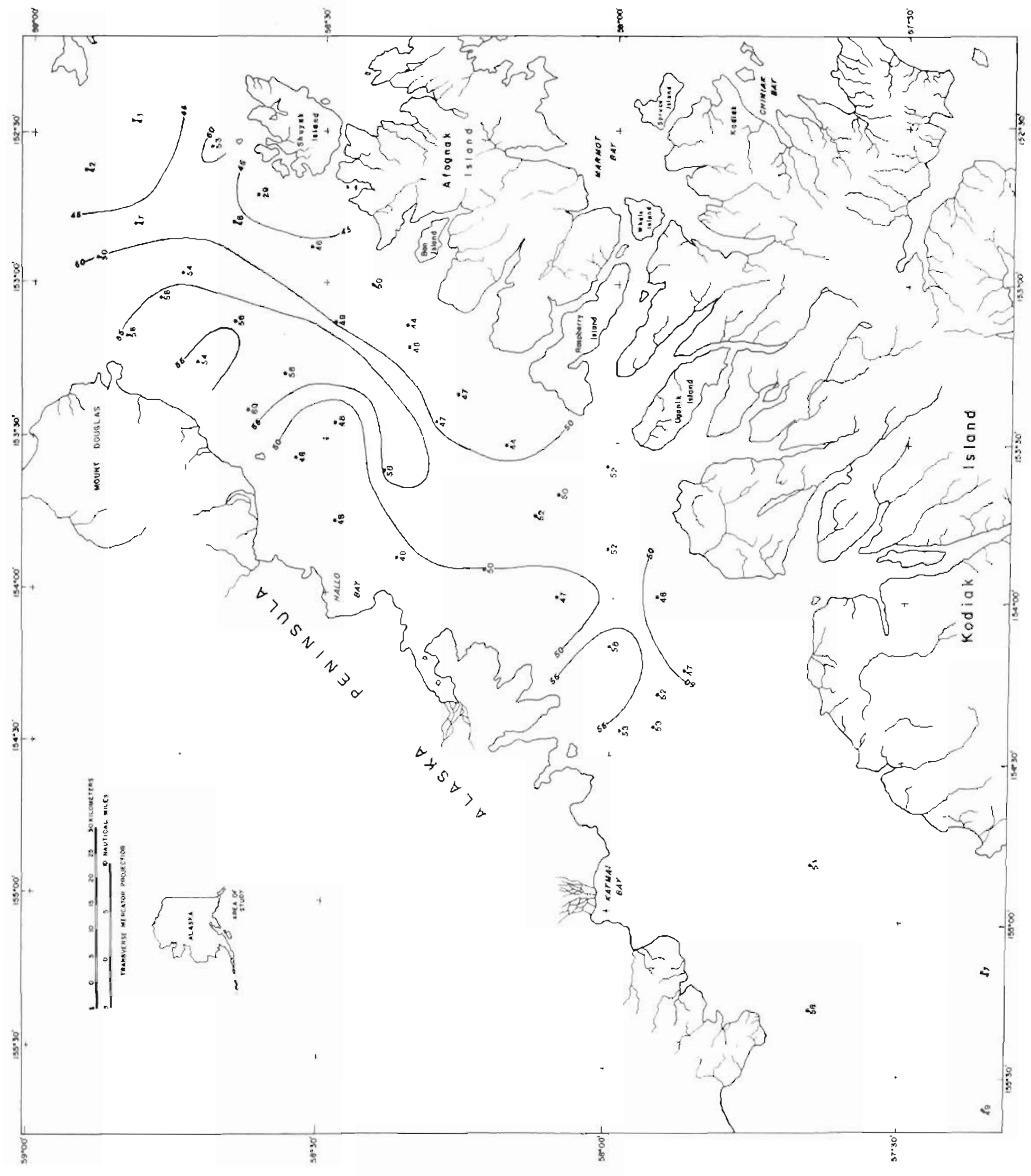

$\approx$
$\therefore$
$\therefore$ 


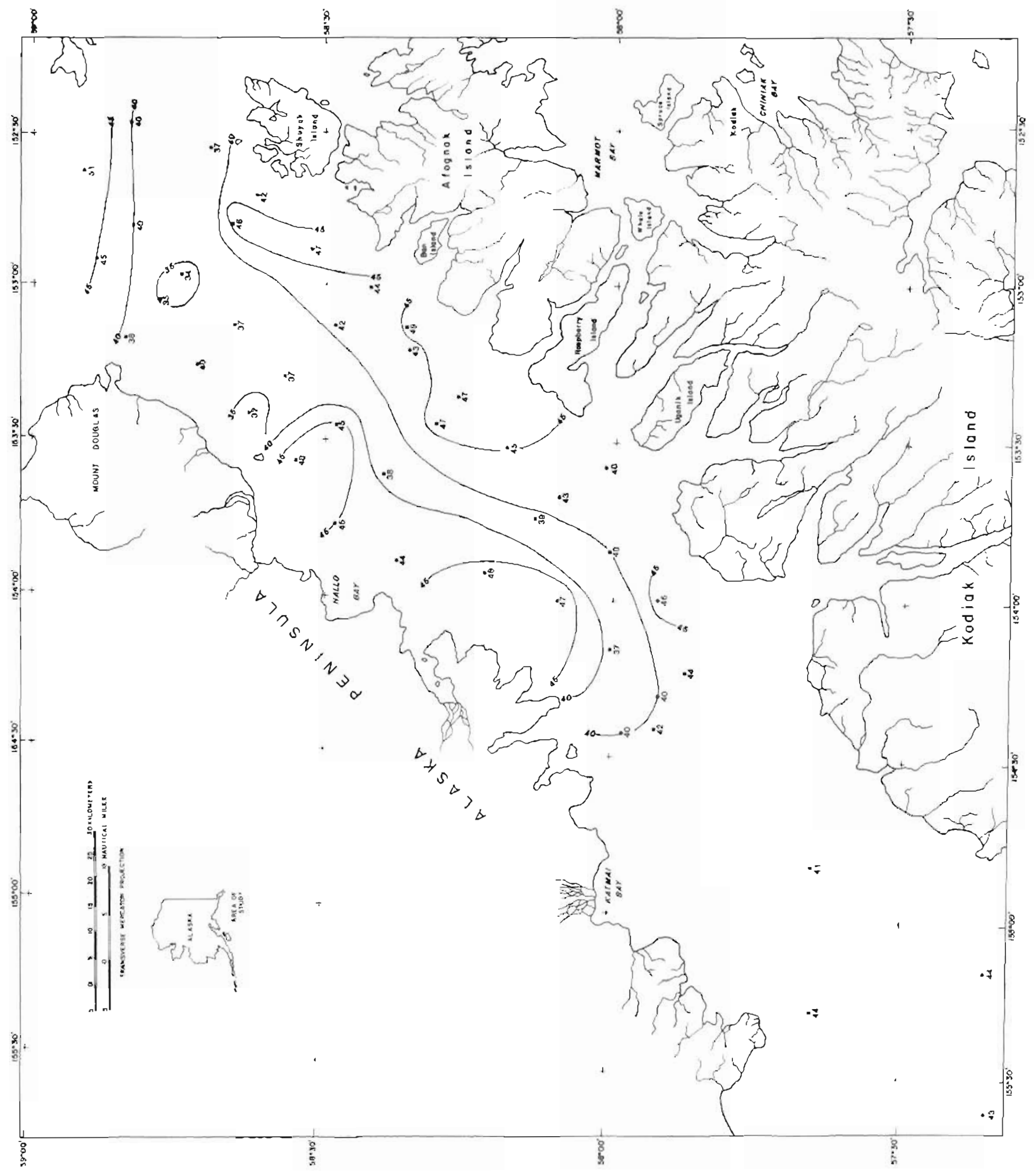




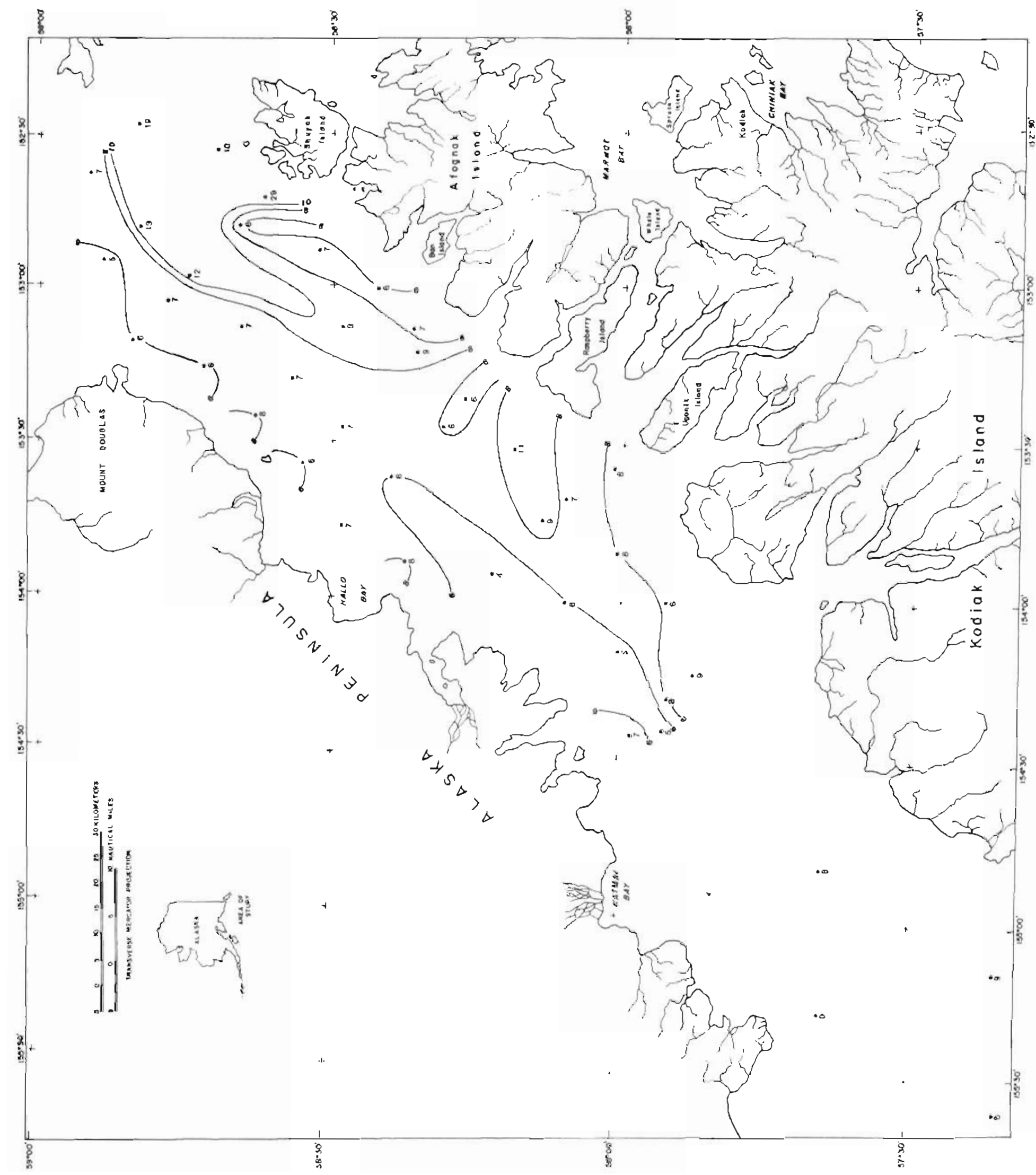




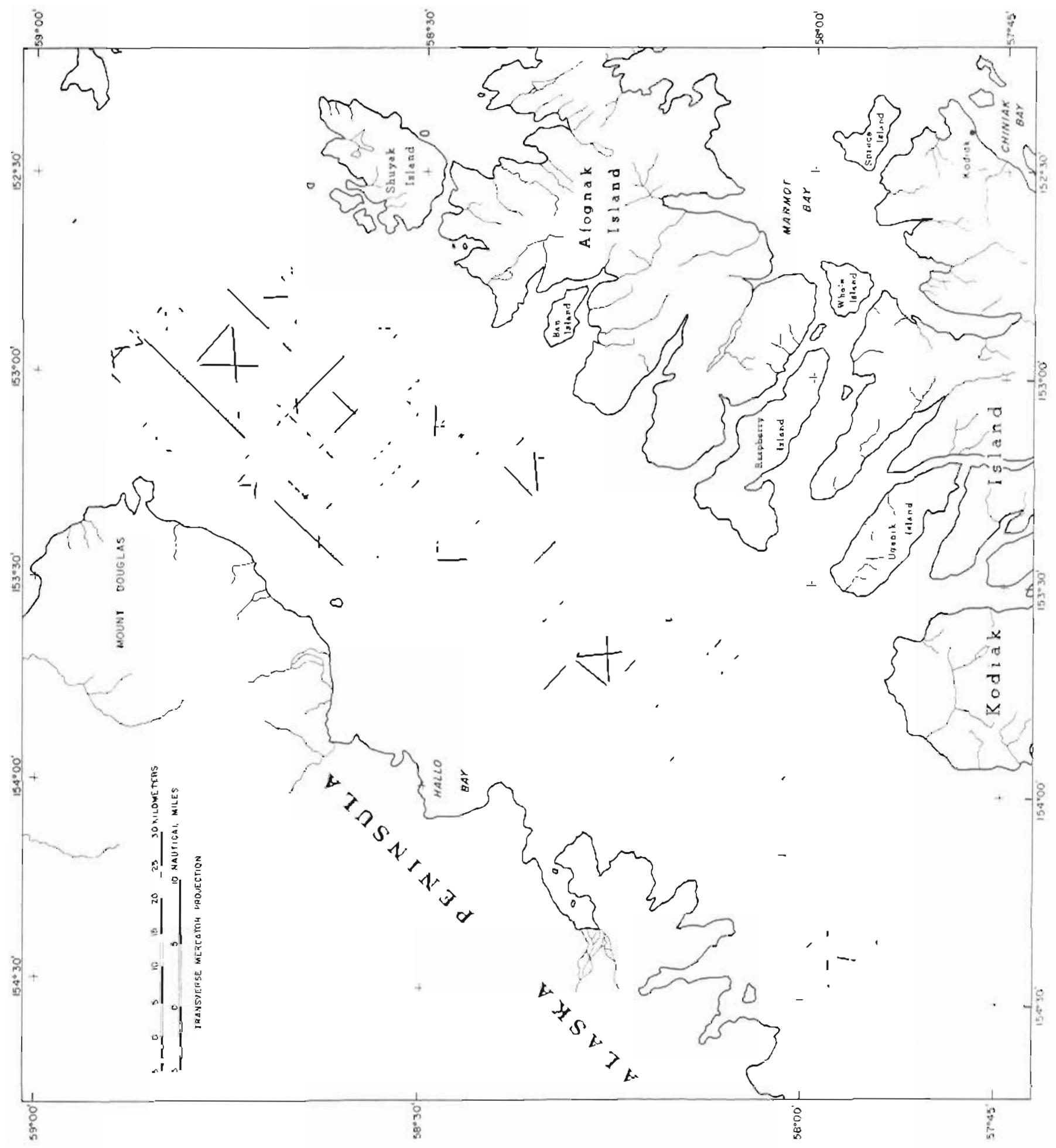




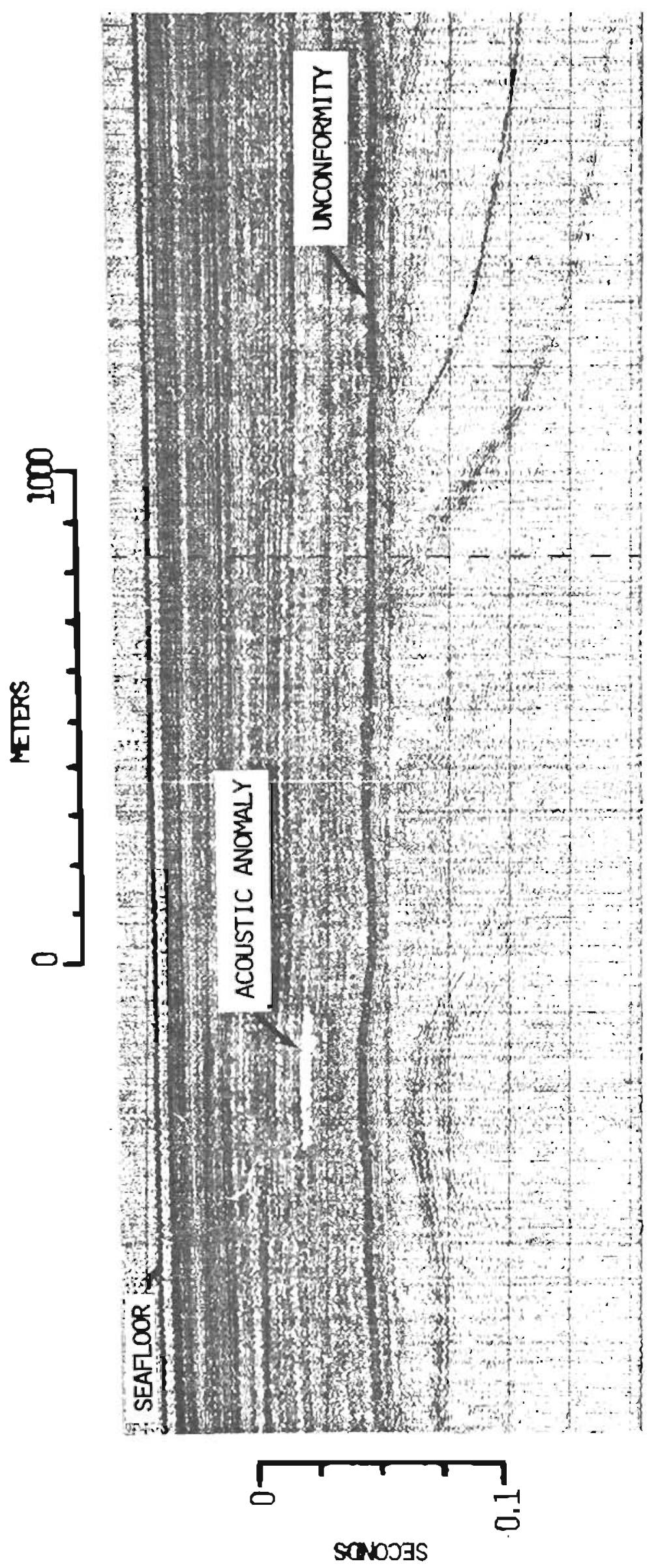

m 


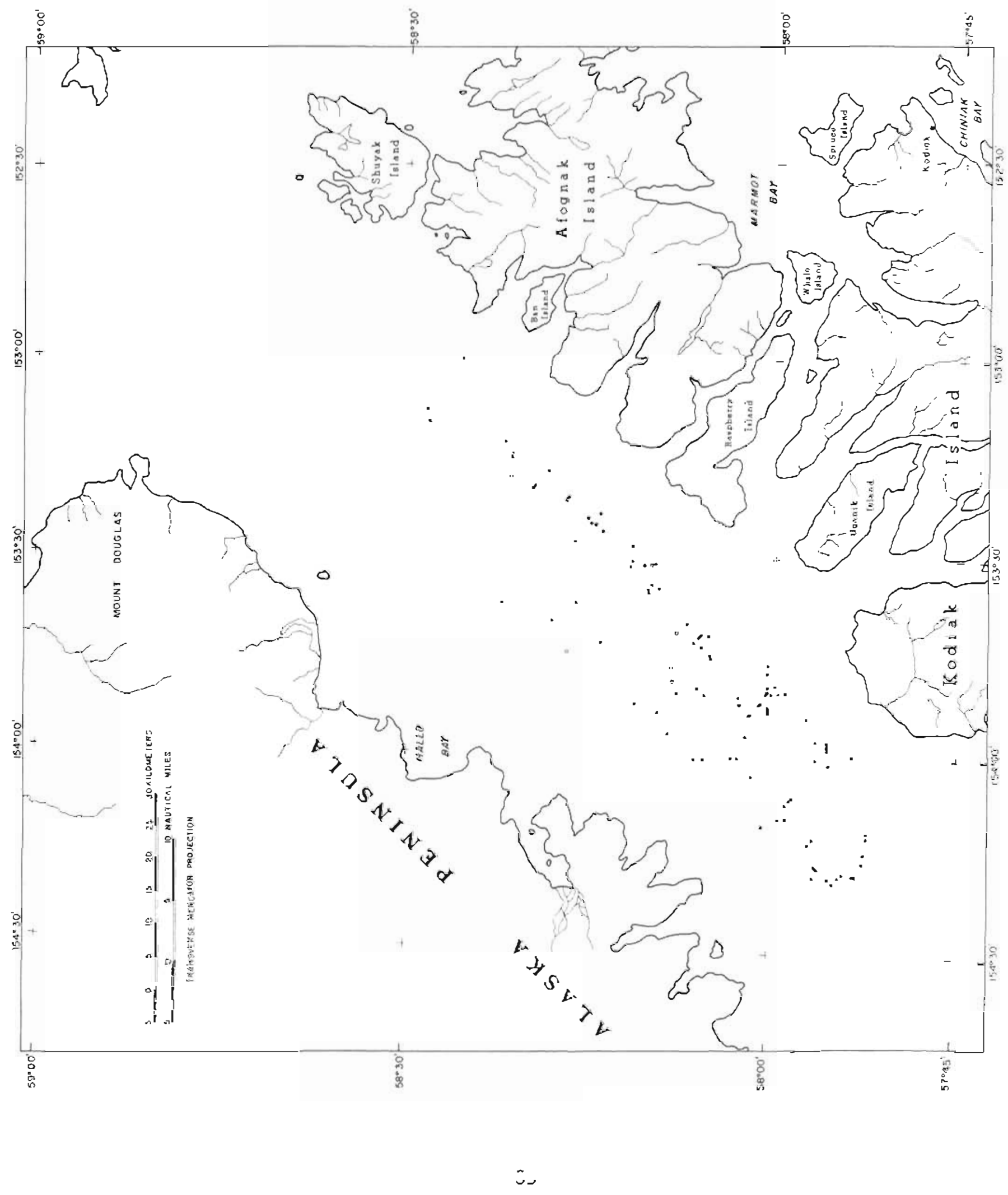




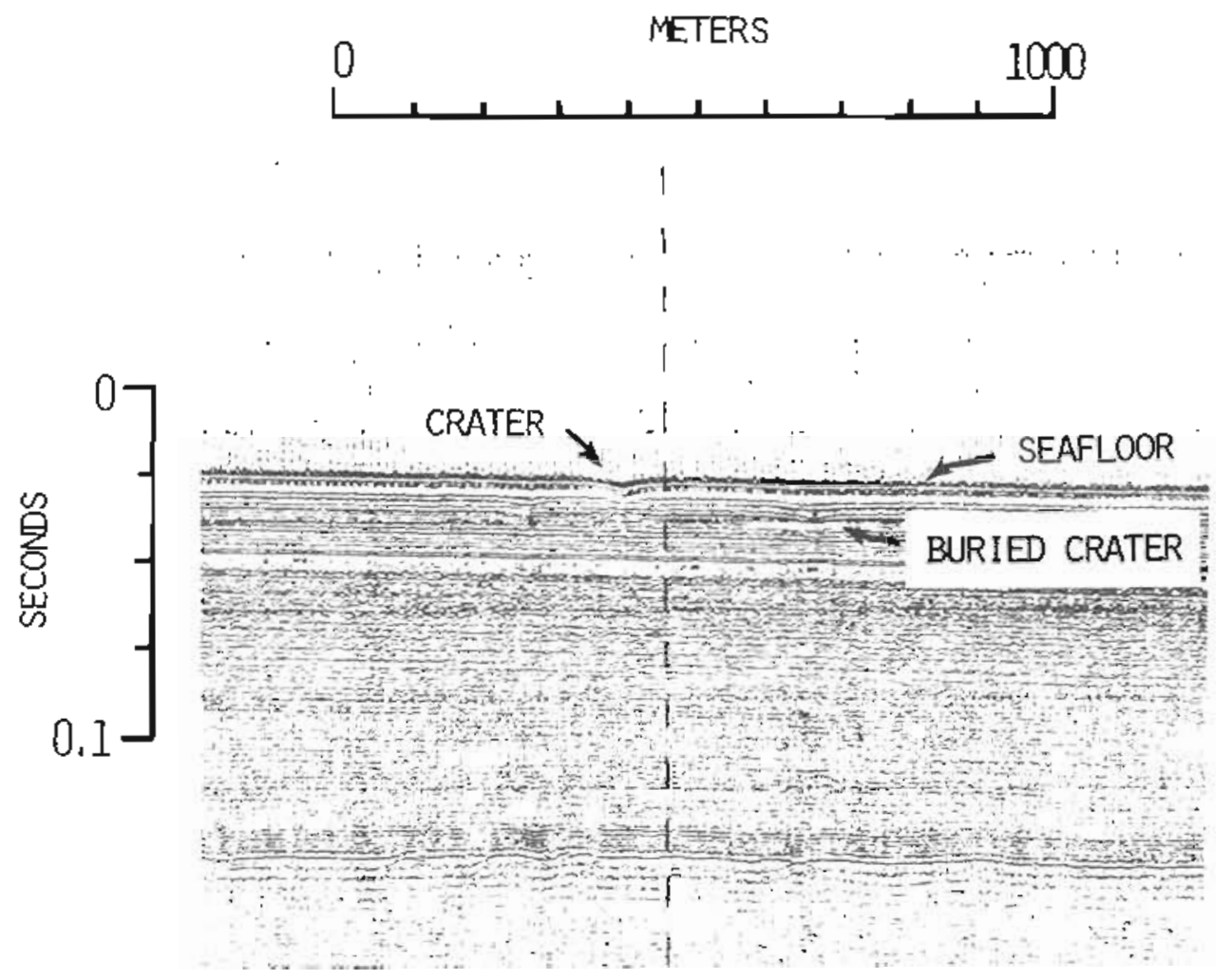




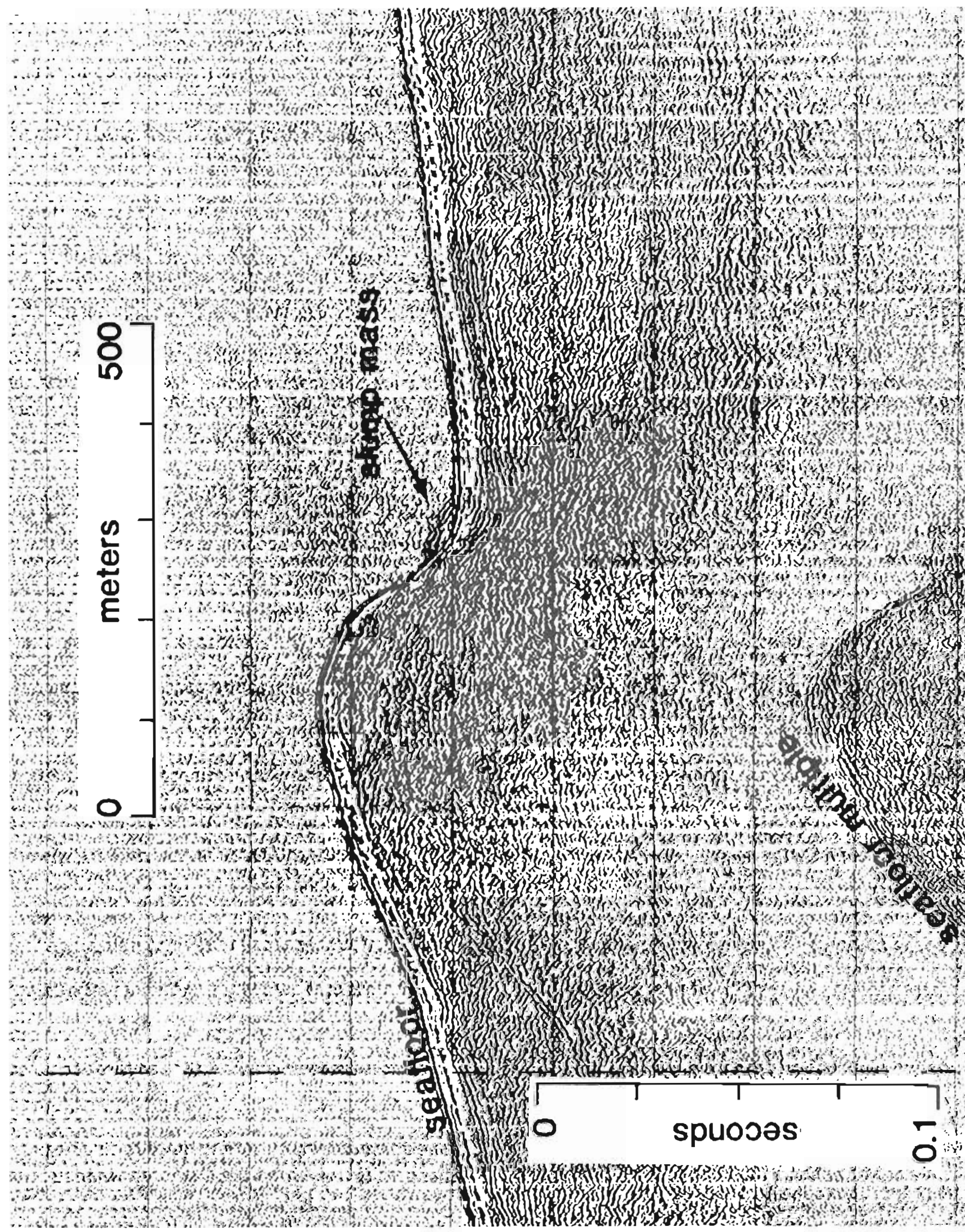

